\title{
Does the Sarbanes-Oxley Act Have a Future?
}

\section{Roberta Romano ${ }^{\dagger}$}

Although the enactment of the Sarbanes-Oxley Act (SOX) received nearly unanimous congressional support, only a few years thereafter its wisdom was increasingly questioned and its supporters had to stave off attempts to recraft the legislation. The financial crisis of 2008 has sidelined efforts to alter the legislation's most costly provision, as Congress's attention has turned to overhauling the regulatory regime for financial institutions. There is, nonetheless, much to be learned about financial regulation and SOX's future, from an in-depth examination of the interplay of the government and private commissions created with an eye to revising the legislation, media coverage of those entities, and congressional responses. That interaction provides a map of political fault lines and assists in forecasting the prospects for recrafting SOX's most costly provision. It also serves as a cautionary tale regarding significant regulation enacted in the midst of a financial-market crisis. The ongoing financial crisis has sidelined SOX, but its burdensome costs suggest that it might well, in due course, reemerge on the legislative agenda.

Introduction

I. The Making of SOX and the Subsequent Pushback .................................235

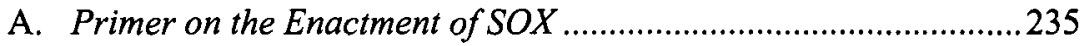

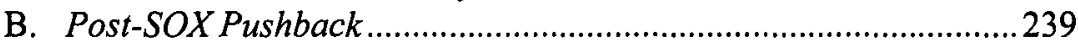

1. SEC Advisory Committee on Smaller Public Companies ...... 239

2. Committee on Capital Markets Regulation..............................244

3. McKinsey \& Company Study for Senator Schumer and Mayor Bloomberg

4. Commission on the Regulation of U.S. Capital Markets in the 21st Century

\footnotetext{
$\dagger$ Oscar M. Ruebhausen Professor of Law, Yale Law School; Research Associate, National Bureau of Economic Research and Research Fellow, European Corporate Governance Institute. This paper is based on presentations at conferences at the Università degli Studi di Napoli Federico II, the University of Nice Sophia Antipolis, and the Federal Reserve Bank of Philadelphia Policy Forum, and in the Queen's University Osler Distinguished Lecture in Business Law series. Gregory Ruben, Yale Law School '08 provided superb research assistance. I am grateful to Richard Geiger and Lisa Tuite, librarians at the San Francisco Chronicle and Boston Globe, for generously searching their newspapers' internal databases for me. I have also benefited from comments by Jennifer Arlen, Dale Oesterle, Robert Thompson, and participants at workshops at the George Mason University Center for Study of Public Choice, the Columbia, Michigan, New York University, Northwestern, Ohio State, and Yale law schools, and the Third Conference on Empirical Legal Studies.
} 
C. The Empirical Literature on SOX and Its Relationship to the Reports' Critiques.

II. The Media and Congress Respond to SOX's Consequences

A. The Relation Between the Media, Issue Saliency, and Public Policy

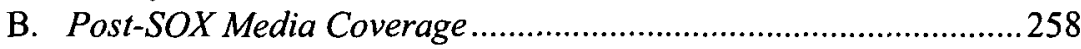

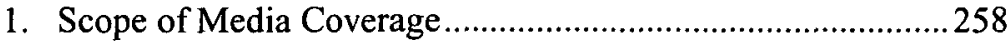

2. Coverage of SOX's Impact on Small Firms and Market Competitiveness.

a. Temporal Pattern of Reporting on Criticisms of SOX.....261

b. Substantive Pattern in the Coverage of SOX Critiques. ...262

3. Coverage of the Commissioned Reports.................................266

a. Coverage of the Advisory Committee ..................................266

b. Coverage of the Capital Markets Committee, McKinsey Study, and Chamber of Commerce Commission.

4. Saliency of Post-SOX Pushback Reporting. 269

5. Interaction Between Interest Groups and Media Coverage for Influencing Public Policy

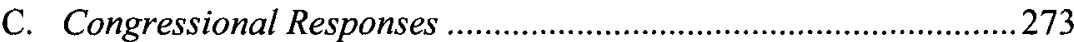

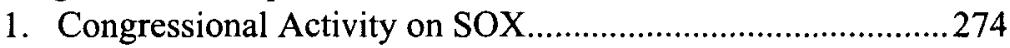

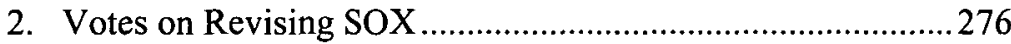

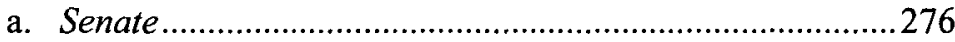

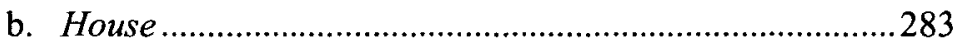

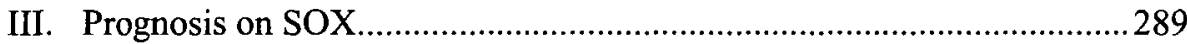

A. The Path of Legislative Revisions ..................................................289

B. Prospects for the Recrafting of SOX ...........................................291

1. The Prospective Impact of Changes in the Political and Economic Environment ........................................................292

2. Predicting SOX's Revision by a Model Focused on Congressional Characteristics

C. A Thought Experiment: If Revised, What Is the Most Probable Scope of Revision of SOX? ............................................................297

D. Market Competitiveness Concerns .................................................302

E. A Lesson of SOX: The Need for Sunset Provisions .........................303

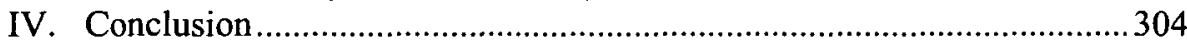

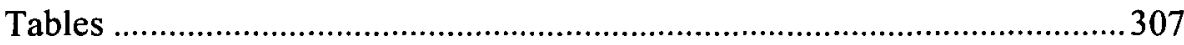

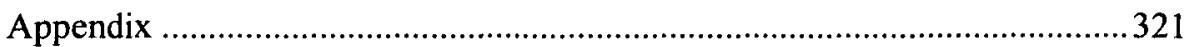

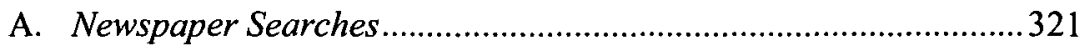

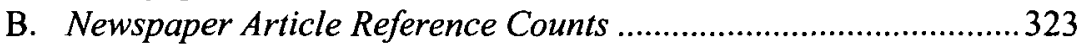

C. Regional Newspapers' Use of Wire Services...................................324

D. Temporal Pattern of Reporting.......................................................326

E. National Press Coverage of the Committee Reports......................328

Appendix Tables 
"There is no way in a million years we will move to an insane regulatory system like Sarbanes-Oxley."

Introduction

The history of federal securities regulation, which began with landmark legislation in the 1930s, can best be broadly characterized as one of episodic expansion of regulatory scope within a disclosure regime. In contrast, most U.S. states' securities laws had prohibited the sale of securities not meeting state regulators' approval. Congress periodically has revisited the scope of federal regulation, with the greatest expansion occurring in the 1960s, when federal regulation was extended to stocks traded over-the-counter and to cash tender offers. ${ }^{2}$ In the 1970 s, Congress enacted legislation requiring public companies to maintain accurate books and records in the wake of the revelation of U.S. companies' questionable payments to foreign officials. ${ }^{3}$ Then, in the 1980 s, after a series of high-profile insider trading cases involving hostile takeovers, Congress increased sanctions for insider trading. ${ }^{4}$

By the 1990s, however, the regulatory imperative took another turn, as Congress focused on class actions and enacted legislation restricting private civil litigation for securities violations. ${ }^{5}$ That legislation reinforced a line of Supreme Court decisions, originating in the 1970s, in which the Court raised the bar for private plaintiffs seeking to recover damages for federal securities violations. ${ }^{6}$ The Securities and Exchange Commission (SEC), by contrast, has sought to overturn court decisions restricting private securities litigation. ${ }^{?}$

1 Martin Graham, overseer of the Alternative Investment Market, the London Stock Exchange's market for small firms, quoted in Carrick Mollenkamp, Alistair MacDonald \& Ann Davis, English Lesson: Uncertain AIM: A Hot Market in London Has Its Risks Too, WALL ST. J., Dec. 20, 2006, at Al.

2 Williams Act, Pub. L. No. 90-439, 82 Stat. 454 (1968) (codified at 15 U.S.C. $\$ \S 78$ a-nn (2006)); Securities Acts Amendments, Pub. L. No. 88-467, 78 Stat. 565 (1964) (codified as amended at 15 U.S.C. $\$ 780(a)(1)(2006)$ ). The Securities and Exchange Commission (SEC) advocated these jurisdictional expansions. However, not all of its expansionary efforts have succeeded; for an account of the agency's failure to obtain jurisdiction over equity derivatives, see Roberta Romano, The Political Dynamics of Derivative Securities Regulation, 14 YALE J. ON REG. 279, 361-80 (1997).

3 Foreign Corrupt Practices Act of 1977, Pub. L. No. 95-213, 91 Stat. 1494 (codified as amended at 15 U.S.C. $\S \S 78 d d$ to dd-3 (2006)).

4 Insider Trading and Securities Fraud Enforcement Act of 1988, Pub. L. No. 100-704, 102 Stat. 4677 (codified as amended at 15 U.S.C $\$ \S 78 \mathrm{a}-78 \mathrm{nn}(2006)$ ); Insider Trading Sanctions Act of 1984, Pub. L. No. 98-376, 98 Stat. 1264 (codified at 15 U.S.C. $\$ \S 78 a-78 n n(2006)$ ).

5 Securities Litigation Uniform Standards Act, Pub. L. No. 105-353, 112 Stat. 3227 (1998) (codified at 15 U.S.C. $\S \S 77$ p, 78bb(f) (2006)); Private Securities Litigation Reform Act, Pub. L. No. 104-67, 109 Stat. 737 (1995) (codified at 15 U.S.C. $\$ \$ 77 \mathrm{z}-1,78 \mathrm{u}-4(2006)$ ).

6 E.g., Emst \& Ernst v. Hochfelder, 425 U.S. 185 (1976) (establishing scienter requirement); Blue Chip Stamps v. Manor Drug Stores, 421 U.S. 723 (1975) (establishing purchase or sale requirement).

7 The Commission has advocated that Congress override Supreme Court decisions, such as Central Bank of Denver, N.A. v. First Interstate Bank of Denver, N.A., 511 U.S. 164 (1994) (rejecting 
Following spectacular corporate failures in 2001 and 2002, Congress once again expanded the reach of federal regulation, with the enactment of the Sarbanes-Oxley Act ("SOX"). ${ }^{8}$ SOX increased the regulation of accounting firms as well as of issuers by creating a new regulator for the accounting profession, the Public Company Accounting Oversight Board ("PCAOB"), and by imposing governance mandates on public companies. The corporate governance requirements include CEO and CFO attestations of internal controls and financial statement accuracy, mandates regarding audit committee composition and functioning, forfeiture of CEO incentive compensation upon issuance of an accounting restatement, and prohibition of executive loans and the purchase of non-audit services from auditors. ${ }^{9}$

A distinctive feature of SOX is its break with the historic federal regulatory approach of requiring disclosure and leaving substantive governance rules to the states' corporation codes. Only a small number of provisions in SOX follow the conventional regulatory strategy of disclosure requirements, and these are decidedly less important in the statute's regulatory schema than the substantive regulations. Even more striking, however, is that only a few years after enactment, widespread dissatisfaction has been expressed over SOX's regulatory cost. In particular, calls for rolling back the most burdensome provision of SOX occurred with increasing frequency, as from 2006 to 2007 a series of government- and privately-sponsored commissions endorsed such an approach.

The commissioned reports' recommendations have been informed by two concerns: a disproportionate impact of SOX on smaller public firms, and a perceived weakening in the competitiveness of U.S. capital markets post-SOX. Underscoring those concerns, the reports point, with varying degrees of emphasis, to a significant decrease in the number of new foreign listings and public offerings on U.S. exchanges, and a commensurate increase in foreign delistings and domestic going-private transactions. The most plausible reading of the empirical academic literature on SOX lends support to the reports' implication that for many firms, any benefit generated by the legislation is incommensurate with the cost.

The sea change in the perception of SOX's value and in the willingness to advance an agenda of lightening its regulatory burden is astounding given the

secondary liability as basis for liability to private plaintiffs under securities laws) in the 1990s. Most recently, in a divided vote, the Commission requested that the Solicitor General file a brief supporting an effort to revive secondary liability for securities violations in private lawsuits, which had been eliminated by the Central Bank decision. The vote is discussed further in note 39, infra.

8 Sarbanes-Oxley Act, Pub. L. No. 107-204, 116 Stat. 745 (2002) (codified at 15 U.S.C. $\S \S 7201-66(2006))$.

9 Sarbanes-Oxley Act $\S 201$ (codified at 15 U.S.C. $\S 78 \mathrm{j}-1$ (g) (2006)) (non-audit services); $\S 301$ (codified at 15 U.S.C. $\$ \S 78 \mathrm{j}-1(\mathrm{~m})(2006)$ ) (audit committee independence and functions); $\S 402$ (a) (codified at 15 U.S.C. $\$ 78 \mathrm{~m}(\mathrm{k})$ (2006)) (executive loan prohibition); $\S 906(\mathrm{a})$ (codified at 15 U.S.C. $\S 1350$ (2006)) (criminal liability for knowingly violating certifications); $\S 302$ (codified at 15 U.S.C. $\S 7241$ (2006)) (certification of financials); $\S 304$ (codified at 15 U.S.C. $\S 7243$ (2006)) (forfeiture of incentive compensation on restatement); $\$ 404$ (codified at 15 U.S.C. $\S 7262$ (2006)) (intemal controls). 
overwhelming support for the legislation at the time it was enacted. As a result, until the financial crisis of 2008 redirected-indeed consumed--legislators' attention, displacing virtually all other legislative matters, SOX's advocates were increasingly finding themselves in a politically defensive posture, having to justify, and stave off attempts to dismantle, key components of the legislation.

Even if the political environment had not altered congressional priorities, SOX's supporters-who include key legislators-would be, of course, in a formidable defensive position. It is a daunting task to revise legislation, given the organization of U.S. politics: there are multiple veto points throughout the legislative process, and a supermajority rather than a majority can be necessary in the Senate to alter the status quo. Namely, the U.S. Constitution requires the approval of both chambers of Congress and the President in order to pass a law; each chamber's rules route bills through subcommittees and then full committees before they can reach the floor for a vote; and under the Senate rules a supermajority of sixty votes is required to invoke cloture and limit debate on legislation. ${ }^{10}$ Notwithstanding a slow-moving legislative process in the absence of the crisis environment that gave rise to SOX, the widespread criticism of SOX has had a discernible effect, causing the. SEC to revisit its implementation in order to take preemptive action that could deflect and drain the energy behind efforts by Congress and business interest groups to revamp the legislation. ${ }^{11}$

The first Part of this Article frames the analysis of SOX by providing a thumbnail sketch of SOX's making: the legislation was enacted in a crisis atmosphere in the wake of a series of spectacular accounting frauds at major public corporations. The first Part then introduces the post-enactment policy debate, as framed by reports that call for alteration in SOX's implementation given its burdening of small firms and U.S. capital markets, and the muted response of key legislators and the SEC to those appeals. Subtle focal differences among the reports highlight the differing agendas of those affected by SOX and thus point to where the political fault lines for coalition bargaining are in consideration of SOX's future. The first Part concludes with a brief overview of the empirical literature that bolsters the concerns raised in the reports.

The second Part of the Article focuses on the responses of the media and of Congress to the critiques of SOX voiced in the commissioned reports. In particular, it analyzes the coverage by leading business journalists and national and regional newspapers of the reports and their critiques of SOX for adversely impacting small firms and U.S. capital markets. The rationale for the inquiry is

10 U.S. CONST. art. I, § 7; STEVEN S. SMITH, JASON M. ROBERTS \& RYAN J. VANDER WIELEN, THE AMERICAN CONGRESS 34, 208, 212, 221-22 (5th ed. 2007).

11 E.g., Commission Guidance Regarding Management's Report on Internal Control over Financial Reporting Under Section 13(a) or 15(d) of the Securities Exchange Act of 1934, 72 Fed. Reg. 35324 (June 27, 2007) (codified at 17 C.F.R. pt. 241 (2008)); infra Part II.B. 
that it will facilitate gauging the political support for revamping SOX, along with the scope that any congressional initiative might take, as the media seeks to inform and shape the debate: an empirical literature has identified a connection between the saliency with which an issue is covered in the media and changes in public policy. The second Part then analyzes congressional responses to the reports and critiques of SOX, including two congressional votes aimed at mitigating the legislation's impact on small firms.

Having sought to gauge the political economy of where we are and how we have gotten here, the final Part provides a prognosis of SOX's future and the impact of the recent financial panic and ongoing economic crisis on those prospects. It begins with an illustration that provides a suggestive and helpful template for evaluating SOX's prospects: Congress's imposition of internal control requirements in the Foreign Corrupt Practices Act (FCPA). Paralleling the aftermath of SOX, only a few years after the FCPA's unanimous adoption in 1977, critics contended that the statute generated significant cost and liability issues, and was adversely affecting the ability of U.S. firms, particularly small ones, to meet foreign competition. ${ }^{2}$ In 1988 , over a decade after its enactment, the FCPA was revised with the aim of addressing those concerns. That response could be characterized as swift in comparison to the recrafting of other ill-advised financial regulation. For example, the Depression-era GlassSteagall Act's separation of commercial and investment banking, which is thought to have contributed to the banking debacle of the 1980 s, took decades to repeal. ${ }^{13}$

The core lesson to be learned from federal financial-market regulation is that modification or repeal of poorly conceived legislation can take years, if not decades, to accomplish, despite the best judgment of those best informed-the academic and business community - that the legislation is, in significant parts, profoundly flawed. With that general backdrop, the Article then evaluates the possibility of SOX's recrafting. It concludes that, notwithstanding considerable dissatisfaction with SOX, absent either a dramatic change in the political environment, or a successful public campaign to link the costs of SOX to a recessionary economy, it could well take a considerable length of time before SOX's most severe shortcomings are adequately addressed.

In the wake of the financial crisis of 2008, Congress appears to be poised to adopt far-reaching reworking of the regulatory architecture for financial institutions. As I read the politics, attitudes toward SOX have not been altered by the crisis-after all, SOX's governance provisions did not prevent financial

12 O. Ronald Gray, The Foreign Corrupt Practices Act: Revisited and Amended, 29 Bus. \& Soc. 11 (1990). The Senate approved its version of the bill, which was identical to a version passed by the Senate 86 to 0 in 1976, by voice vote. 123 CONG. REC. 13818 (1977). The House did not act that year. The House's votes to approve its own bill, and to replace the Senate bill with its own bill, were also voice votes. 123 CONG. REC. 36306,36308 (1977). The conference report was approved in the Senate by voice vote, 123 CONG. REC. 38603 (1977), and in the House by a recorded vote of 349 yeas, 0 nays, and 85 not voting. 123 CONG. REC. 38779 (1977).

13 James R. Barth, R. Dan Brumbaugh, Jr. \& James A. Wilcox, Policy Watch: The Repeal of Glass-Steagall and the Advent of Broad Banking, 14 J. ECON. PERSP. 191, 192 (2000). 
firms' collapse. Rather, SOX has moved down on the policy agenda as congressional priorities have shifted to respond to a financial panic and the most severe economic crisis since the Great Depression. This shift in congressional priorities, in my judgment, makes this Article's focus considerably more timely: the politics of SOX, in which hastily crafted legislation imposes costs incommensurate with the benefits but a cumbersome legislative process renders it daunting to repeal provisions creating a drag on economic activity, should serve as a cautionary tale for those wishing to enact comprehensive financial-market reform.

\section{The Making of SOX and the Subsequent Pushback}

SOX was enacted toward the end of July 2002 , a few days after the bankruptcy filing of WorldCom. That event was the culmination of a series of spectacular accounting scandals commencing with Enron's collapse in the fall of 2001. Congress held numerous hearings on Enron's demise, and the legislative response began in March 2002 with the passage of campaign finance reform, ${ }^{14}$ a subject far afield from both SOX and the specific circumstances of Enron's decline. The making of SOX took less than half a year, as the initial House committee hearings were held in December 2001 in the wake of Enron's bankruptcy filing, and it was not until March that any hearing focused on a specific legislative proposal. ${ }^{15}$

\section{A. Primer on the Enactment of SOX}

Throughout the time frame in which Congress considered a legislative response to the Enron scandal, the stock market was tanking. The stock market low-which represented a loss of more than one-third of the value of the S\&P 500 composite index from the previous year-occurred two days after WorldCom's bankruptcy filing, while the legislation was in conference after the two chambers enacted different bills. ${ }^{16}$ The stock-market low was also only a few months before the 2002 midterm elections. Not surprisingly, members of Congress were particularly attentive to market events: the drop in the market spurred the Senate into action. In the floor debate on the bill, senators referred

14 Bipartisan Campaign Reform Act of 2002, Pub. L. No. 107-155, 116 Stat. 81 (codified as amended at 2 U.S.C. $\$ \S 431-42$ (2006)). For a discussion of how the Enron scandal resuscitated campaign finance reform, see Allan J. Ciglet, Enron, a Perceived Crisis in Public Confidence, and the Bipartisan Campaign Reform Act of 2002, 21 REV. POL'Y RES. 233 (2004).

15 The Corporate and Auditing Accountability, Responsibility, and Transparency Act of 2002: Hearings on H.R. 3763 Before the H. Comm. on Financial Servs., 107th Cong. (2002) (hearings on bill held March 13 and 20,2002, and on the minority bill April 9, 2002). The enacted legislation was the Senate bill, on which no hearing was ever held. Roberta Romano, The Sarbanes-Oxley Act and the Making of Quack Corporate Governance, 114 YALE L. J. 1521, 1570 (2005).

16 Romano, supra note 15 , at 1546-47, 1557-58. 
to the steep market decline as a compelling rationale for legislation. ${ }^{17}$ Such a response to a financial crisis is certainly not exceptional. Most securities legislation in the United States, as well as the United Kingdom, has been enacted in the wake of stock market crashes. ${ }^{18}$

As the market was collapsing, public confidence in business was also declining, reaching a low point in the June 2002 Gallup public opinion poll, in which only $20 \%$ of respondents expressed confidence in business. Over the previous six years the proportion had ranged between $28 \%$ and $31 \% .{ }^{19}$ No doubt the drop in public confidence was related to the drop in the stock market. The correlation between the S\&P 500 composite index and the percentage of the public expressing confidence in business is significantly positive. ${ }^{20}$ Also, not surprisingly, the accounting scandals became the subject of a media frenzy, and that frenzy would appear to have further contributed to a shift in sentiment by increasing the salience of the scandals. From January to July 2002, 471 of 613 business-related news stories on the major network evening news were on corporate scandals, compared to 52 of 489 business stories in the same period the previous year. While 195 of the stories connected Congress to the scandals, 188 connected the scandals to the Bush Administration. ${ }^{21}$ Even more to the point, over $80 \%$ of those news stories looked to government to solve the perceived problem. ${ }^{22}$

It was not, however, self-evident that legislation would be enacted prior to WorldCom's demise. That firm's failure renewed calls in the media for legislative action and criticism that the Republican Party's legislative program was woefully inadequate, that is, not sufficiently regulatory in approach. ${ }^{23}$

The House, which the Republicans controlled, had passed a bill in April. The Senate did not begin consideration of legislation until July. The Democrats

$17 I$ Id. at 1546 \& n.69 (citing 148 CONG. REC. S6558 (daily ed. July 10, 2002) (statement of Sen. Reid) ("[T]he stock market dropped again today almost 300 points. We need to do something to reestablish credibility and to reestablish ... confidence.... This legislation goes a long way toward that end.")).

18 Stuart Banner, What Causes New Securities Regulation? 300 Years of Evidence, 75 WASH. U. L.Q. 849 (1997).

19 Gallup polls are compiled in Romano, supra note 15 , at 1525.

20 Id. at $1524 \mathrm{n} .7$.

21 The data on media coverage are reported in Video: Karlyn H. Bowman, Sarbanes-Oxley and Public Opinion After Enron and WorldCom, Presentation at Sarbanes-Oxley: A Review (May 4, 2004), http://www.aei.org/events/eventID.809, filter.all/event_detail.asp (follow "video" link, at 00:13:45), and were compiled by the Media Research Center. James Hamilton contends that television news coverage is driven by financial considerations. In particular, he contends that news content is directed at the marginal viewing audience most desired by advertisers: young women. This audience tends to be liberal and more interested in "soft" news, such as human interest stories and stories about crime and the problems of families with children, than "hard" news about public affairs or business. James T. Hamilton, all the News That's Fit To Sell: How the Market Transforms INFORMATION INTO NEWS (2004). The heightened business news coverage related to the scandals, such as the loss of jobs and pensions of Enron employees, would, in fact, seem to fit comfortably in the category of human interest stories that appeal to the viewers the networks would seek to attract.

22 Bowman, supra note 21.

23 Romano, supra note 15 , at $1556-58,1567$. 
narrowly controlled the Senate with a bare one-vote majority and needed bipartisan support in committee to have any possibility for success in enacting a bill. ${ }^{24}$ Until the WorldCom scandal broke, the Senate ignored the House bill, and the Senate bill was languishing in committee. ${ }^{25}$ Now spurred into action by the revelation of fraud at yet another large public corporation, the Senate severely limited consideration of the legislation by adopting a cloture motion, which restricts debate time and permissible amendments. ${ }^{26}$

Indeed, Senate Republicans, who had been criticized in the media for adopting a dilatory strategy, began to press for expedited consideration, calculating that they would fare better in conference and be able to negotiate a bill closer to the House than the Senate one. That was not to be, for shortly after the conference commenced, WorldCom filed for bankruptcy, and as one lobbyist put it, "When the WorldCom scandal hit, it became ... a very different attitude and atmosphere, if not a political tsunami." Republicans capitulated, fearing further revelations of corporate misconduct and that delay in acting on legislation to address the scandals would be politically perilous. ${ }^{27}$ The conference rapidly concluded with adoption of the Senate bill. It was widely perceived in the media that the motivation for SOX's enactment was legislators' apprehension over the upcoming election, with the priority focused on definitive action rather than substantive content. ${ }^{28}$

24 The Senate work product is thought to be less partisan than that of the House because Senate rules require a supermajority-60\%-to end debate and move on legislation, rather than a majority, and as was the case in 2002, the majority party most typically does not have supermajority control. See Sarah A. BINDER, STALEMATE: CAuSES AND CONSEQUENCES OF LEgISLATIVE GRIDLOCK 98 (2003); Romano, supra note 15, at 1545.

25 The Senate bill was drafted by the liberal Democrat Finance Committee Chairman, Paul Sarbanes, as an alternative to the less intrusive regulatory approach of the House Republicans' bill. According to a well-accepted and widely used measure by political scientists of legislators' ideology (the "DW-NOMINATE" score, constructed by Keith Poole and Howard Rosenthal), for the 107th Congress in which SOX was enacted, Senator Sarbanes' score of -.55 was in the most liberal quintile of Democrats. The scores and a brief explanation of the methodology are available on Poole's website. Keith T. Poole, NOMINATE Data, http://voteview.com/dwnl.htm (last visited June 9, 2009). For a more detailed discussion of the methodology, see KeITH T. POOLE \& HOWARD ROSENTHAL, CONGRESS: A POLITICAL-ECONOMIC HISTORY OF ROLL CALL VOTING (1997).

26 For a more detailed analysis of the legislative process, see Romano, supra note 15, at 1554.

27 Id. at 1567.

28 See, e.g., David E. Sanger, Bush, on Wall St., Offers Tough Stance, N.Y. TiMES, July 10, 2002, at Al ("Democrats have now seized on [the need for drastic legislative change in response to accounting scandals] as a crucial issue for the November elections") (reporting on a speech by President Bush and emphasizing how "partisan the battle has become"); Linda Douglass, World News Tonight (ABC television broadcast July 24, 2002) ("This was a stampede .... The House Republicans dropped their opposition to this legislation because there was simply too much pressure on them to pass something."). This scenario suggests a totally different behavioral connection between elections and legislation than that of Bryan Jones and Frank Baumgartner. They evaluate the electoral connection only retrospectively, contending that elections only affect legislation enacted in a Congress's first session as the session in which there is legislative turnover (as newly elected legislators are seated). BRYAN D. JONES \& FRANK R. BAUMGARTNER, THE POLITICS OF ATTENTION: HOW GOVERNMENT PRIORITIZES PROBLEMS (2005). As illustrated by SOX, elections can also have a prospective impact on the legislative agenda, thereby affecting legislation enacted in the second session, as members act, with reelection in mind, to reassure constituents. 
The confluence of spectacular financial scandals, a declining stock market, waning public confidence in business, and a media frenzy in an election year resulted in a restricted legislative debate and progressively more lopsided votes in support of greater regulation. Although House Democrats supported their own bill, they still voted for the majority's bill after their own bill was predictably defeated along party lines. ${ }^{29}$ And when the bill that emerged from the conference committee was the Democratic Senate's version, all but three House Republicans voted for it. ${ }^{30}$ The Senate votes on the bill were all unanimous. ${ }^{31}$ In short, there was overwhelming, bipartisan support for the legislation.

An important factor that may have influenced Republicans to support the Democrats' bill was that a key interest group generally identified with the Republican Party, the business community, split over the legislation: the Business Roundtable, whose membership consists of the largest corporations, supported the Senate bill, while the Chamber of Commerce, which has many small-firm members, opposed it. ${ }^{32}$ When core constituents disagree on an issue, there is no obvious side for a legislator to support. With the news media severely criticizing the House bill as being too lax on corporate wrongdoers compared to the Senate bill, the split among key business constituents gave Republicans little reason to fight for their bill and risk alienating other constituents, such as individuals whose pensions and stock portfolios had declined markedly in the wake of the scandals and the market break. But even a unified business community would likely have had insurmountable difficulty in preventing the legislative steamroller favoring Senator Sarbanes' bill, given a distrustful environment toward business and the high public salience of the issue.

29 The vote was 334-90 in favor of the Republican bill; the vote on the defeated substitute bill of the Democrats was 202-219, and on a final attempt to amend the Republican bill by the Democrats, 205-222. 148 CONG. REC. 5544-48 (2002) (roll nos. 108-110). Three months later, when the Senate moved on the more restrictive regulatory bill of Senator Sarbanes in place of the House bill, House Republicans introduced a bill to increase criminal sanctions for fraud in response. The vote for that bill was even more one-sided in favor, 391-28. Id. at 13,088-89 (2002) (roll no. 299).

30 Id. at 14,404-06 (2002) (roll no. 348) (conference report adopted by vote of 423-3).

31148 CONG. REC. 12,508 (2002) (roll no. 169); id. at 12,518 (2002) (roll nos. 170-71); id. at 12,961 (2002) (roll nos. 174-75); id. at 14,458 (2002) (roll no. 192) (conference report adopted by vote of 99-0). The vote on the cloture motion that restricted debate on the bill was also virtually unanimous at 91-2. Id. at 12,734 (2002). There were only two split votes, both on amendments offered by Republican Senator McConnell that sought to impose certain disclosure and certification obligations on labor union officers and plaintiffs' attorneys; they received support from members of his party but not from Democrats. Id. at 12,500 (2002) (roll no. 168) (defeated 55-43); id. at 12,656-57 (2002) (roll no. 172) (defeated 62-35). Earlier in the process, by contrast, Banking Committee votes on the bill often split along party lines; the final vote approving the bill was 17-4, with six of ten Republicans voting with the Democrats in favor. Romano, supra note 15 , at $1556 \mathrm{n} .90$.

32 E.g., Brian Tumulty, Momentum Builds for Corporate Accounting Legislation, GANNETT NEWS SERVICE (July 9, 2002) (discussing opposition by Chamber of Commerce to provisions in Sarbanes bill and noting conflict with Business Roundtable's endorsement of the bill's enactment). 


\section{B. Post-SOX Pushback}

Two key developments have framed the post-enactment debate over SOX. The first is the substantial expenditures firms have incurred to comply with section 404-which requires management to certify the adequacy of its internal controls and the outside auditor to attest to management's certification-and the concern that small firms will incur disproportionately large costs when they have to comply with the provision. ${ }^{33}$ The second development involves capitalmarket trends suggesting a decline in the New York stock markets' competitive position compared to foreign exchanges, particularly the London Stock Exchange. These developments have been the focus of four commissioned reports. ${ }^{34}$ Table 1 summarizes the reports' key recommendations, particularly those related to SOX, and indicates where the recommendations diverge; the discussion that follows focuses on recommendations regarding section 404, which has emerged as the critical point of contention regarding SOX.

\section{SEC Advisory Committee on Smaller Public Companies}

The SEC Advisory Committee on Smaller Public Companies ("Advisory Committee") was established in early 2005 by then SEC Chairman William Donaldson, in response to numerous complaints by small firms regarding SOX compliance costs, and in particular, the projected cost of complying with section $404 .{ }^{35}$ Its mission was to advise the SEC on how to assure that

33 Small firms have not yet had to comply with section 404: the SEC postponed the section's implementation for "non-accelerated filers," a term that did not appear in any prior SEC rule, but that refers to a firm with a public float of less than $\$ 75$ million, given the definition of "accelerated filers" in Rule 12b-2 of the Securities Exchange Act, 17 C.F.R. § 240.12b-2 (2008) ("Accelerated filers" are firms with a public float of at least $\$ 75$ million). See Management's Report on Internal Control over Financial Reporting and Certification of Disclosure in Exchange Act Periodic Reports, 68 Fed. Reg. 36,636 (June 18,2003 ) (codified in scattered parts of 17 C.F.R.) (compliance date for non-accelerated filers is "first fiscal year ending on or after April, 15, 2005," compared to June 15, 2004 for accelerated filers); and Extension of Compliance Dates, 69 Fed. Reg. 9,722 (Mar. 1, 2004) (codified in scattered parts of 17 C.F.R.) (extending compliance date for internal control report to fiscal year ending on or after July 15, 2005 for non-accelerated filers and November 15, 2004 for accelerated filers). The effective date for accelerated filers' compliance was not extended further, in contrast to that for non-accelerated filers, as discussed below.

34 Following those reports, a fifth Commission on Enhancing Competitiveness was created in May 2007 by the Financial Services Roundtable, the trade association for the largest financial services companies, to devise a financial services sector "competitiveness" regulatory agenda and advocate "principles-based" regulation. Press Release, Financial Servs. Roundtable, Comm'n on Enhancing Competitiveness (May 23, 2007), http://www.fsround.org/media/pdfs/CommissiononEnhancing CompetitivenessRelease.pdf. Because this commission focused on one sector's concerns, taking as its premise the competitiveness critiques of SOX of the earlier reports discussed in the text, rather than advancing an independent analysis, it is not included in the discussion.

35 Advisory committees are official public entities whose creation and activities are regulated by federal law. Following the statutory procedure, the SEC Chairman announced his intent to establish an advisory committee in December 2004, and the committee was established when its charter was filed with Congress in March 2005. SEC Advisory COMM. ON SMAller PUB. Cos., FinAl Report 10

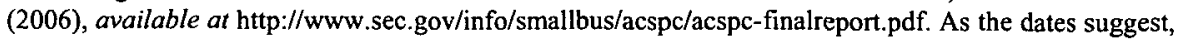


regulatory costs for smaller companies would not be greater than the benefits. The Advisory Committee held public hearings across the country, a decision that undoubtedly generated increased publicity and support for small firms' concerns. It issued an interim report in August 2005 that recommended further delay in the implementation of section 404. The SEC adopted this recommendation, extending the implementation date another year to 2007. The report also proposed a new working definition of "small": firms in the bottom $6 \%$ of total U.S. equity market capitalization (roughly, firms with market capitalization under $\$ 787$ million). ${ }^{36}$

The Advisory Committee's final report was issued in April 2006. Its principal recommendation was to exempt small firms from section 404, the provision requiring management's evaluation of, and auditor attestation to, the effectiveness of internal controls. ${ }^{37}$ Although firms fitting into the proposed carve-out would have been a small fraction of the market value of publicly traded firms, they would have been large in number: $78.5 \%$ of public companies. $^{38}$ The recommendation, which was not unanimous, would consequently have exempted a far larger proportion of firms than those for whom section 404 compliance had been deferred, which amounted to $44 \%$ of public companies. ${ }^{39}$

The report emphasized, as a key rationale for the need for exemptive relief, that studies of 404 compliance had found that actual expenditures were wildly in excess of the per-firm cost estimated by the SEC to cover compliance (in the millions of dollars versus $\$ 91,000$ ). Even with a reduction in compliance costs in the second year of operating under the statute, average

the SEC was aware early on of problems the provision was causing compliant firms and accordingly was expected to cause small firms. The regulations implementing section 404 established a two-tier system of "accelerated" filers (larger corporations, whose market capitalization exceeded \$75 million), which had to comply by the first fiscal year ending after April 2004, and "non-accelerated" filers (small and foreign corporations), for which compliance was deferred an additional year to 2005. See supra note 33. The compliance deadline for the non-accelerated group was further deferred to 2006 as the Advisory Committee was being formed.

36 SEC ADVISORY COMM., supra note 35, at 11 (public meetings); id. at C-3 (interim recommendation regarding extension); $i d$. at C-9 (recommendation of adoption of definition for smaller public company). The SEC adopted the Advisory Committee's recommendations. Internal Control over Financial Reporting in Exchange Act Periodic Reports of Non-Accelerated Filers and Newly Public Companies, 71 Fed. Reg. 76,580, 76,582 (Dec. 21, 2006) (codified at 17 C.F.R. pts. 210, 228, 229, 240, and 249) (2008).

37 Adding a revenue filter to the market cap definition it had previously proposed for a small firm, the Advisory Committee recommended exemption from section 404 entirely for the smallest firms (microcap firms with revenues less than $\$ 125$ million and smallcap firms with revenues less than $\$ 10$ million) and from the provision's auditor attestation component for small firms with revenues less than $\$ 250$ million (but greater than the revenue ceilings established for complete exemption). Microcap companies are those in the bottom $1 \%$ of total U.S. stock market capitalization, while smallcap companies are those in the next lowest $5 \%$ capitalization.

38 SEC ADVISORY COMM., supra note 35 , at 5.

39 Internal Control over Financial Reporting in Exchange Act Periodic Reports of NonAccelerated Filers and Newly Public Companies, 71 Fed. Reg. 76,580 (Dec. 21, 2006) (codified in scattered parts of 17 C.F.R.). Three of the twenty-one members of the Committee dissented from the recommendation: the two members from big four accounting firms and the managing director of the CFA Center for Financial Market Integrity, a unit of the nonprofit association of investment analysts. 
expenditures were still considerable, particularly for smaller firms $(\$ 900,000) .{ }^{40}$ Compliance costs for the smallest firms (non-accelerated filers not yet compliant) were expected to be much higher as a percentage of revenue. While not yet having to comply with section 404 , audit fees had roughly tripled as a percentage of revenue for smaller public companies from 2000 to 2004 (before and after SOX) and, as the Committee noted, best estimates from the expenditures of already compliant larger firms placed external audit fees at only one-quarter to one-third of section 404 compliance costs. ${ }^{41}$

The Advisory Committee further noted that SOX had introduced additional ongoing increased expenditures for smaller firms, which, apart from internal controls, were insignificant for large firms. For example, small firms were less likely than large firms to have a sufficient number of independent directors to meet the stock-exchange requirements adopted in conjunction with SOX along with SOX's audit committee mandates, and the expenses from an increased board size are recurring. ${ }^{42}$ A recent study lends support to the Advisory Committee's contention, as it finds that director compensation costs have risen dramatically, and disproportionately, for small firms post-SOX. ${ }^{43}$

Besides documenting that small firms would bear far greater costs than large firms, the Advisory Committee further emphasized the disproportionate burden 404 imposes on smaller firms because of their organizational structures and more limited resources, personnel, and revenue to offset implementation. ${ }^{44}$ In particular, decisional authority is more concentrated in top management of smaller public companies, while their span of control is greater and there are

40 The SEC estimated that the average annual internal cost of compliance for section 404 would be $\$ 91,000$ over the first three years in its 2003 regulatory release implementing the provision. SEC ADVISORY COMM., supra note 35 , at 39 . The agency also estimated in that release that small firms would spend only $\$ 35,286$ a year on internal controls compliance. Management's Report on Internal Control over Financial Reporting and Certification of Disclosure in Exchange Act Periodic Reports, 68 Fed. Reg. 36,636 (June 18, 2003) (codified in scattered parts of 17 C.F.R.). The actual compliance figures noted by the Advisory Committee are from a study commissioned by the big four accounting firms. Lineke Sneller and Henk Langendijk compiled several studies' estimates of compliance costs along with an actual case study, all of which indicate a staggering misestimation, by several orders of magnitude, of the cost by the SEC (whether one uses the SEC estimate they report of $\$ 34,300$, or the $\$ 91,000$ reported by the Advisory Committee). Lineke Sneller \& Henk Langendijk, Sarbanes Oxley Section 404 Costs of Compliance: A Case Study, 15 CORP. GovernanCE 101 (2007).

41 SEC ADVISORY COMM., supra note 35 , at 34 . Several studies, along with surveys by the Financial Executives Institute and the law firm Foley \& Lardner LLP, have reported dramatic increases in audit fees, in addition to the Advisory Committee's data derived from an SEC report. E.g., Susan W. Eldridge \& Burch T. Kealey, SOX Costs: Auditor Attestation under Section 404 (2005) (unpublished manuscript), available at http://ssrn.com/abstract $=743285$; James S. Linck, Jeffrey M. Netter \& Tina Yang, The Effects and Unintended Consequences of the Sarbanes-Oxley Act, and Its Era, on the Supply and Demand for Directors, REV. FIN. STUD. (forthcoming 2009), available at http://ssrn.com/abstract $=902665$; Sneller \& Langendijk, supra note 40 . Throughout the period, the percentage of revenues that audit fees represent for smaller companies is much higher than it is for large companies.

42 SEC ADVISORY COMM., supra note 35 , at 39.

43 Linck et al., supra note 41.

44 SEC ADVISORY COMM., supra note 35, at 23. 
fewer personnel among whom tasks can be segregated to achieve internal controls than would be considered effective under conventional standards. ${ }^{45}$ As a consequence, in contrast to large firms, in small firms, top management directly oversees financial accounting and will be more likely either to catch accounting fraud or to be intimately involved in the fraud by managerial override of controls. ${ }^{46}$

Furthermore, the features that the Committee considered to be the hallmark of small- compared to large-firm operations-greater fluidity and flexibility of processes and individual tasks that are frequently shifted to meet changing corporate needs as a business grows-render compliance difficult because such firms do not have static processes with well-defined boundaries that can be easily documented in an internal controls system. ${ }^{47}$ Accordingly, in the Advisory Committee's judgment, the approach of the legislation and its implementation by the SEC, which can be characterized as a "one-size-fits-all" mentality, demonstrated a thorough misunderstanding of what internal controls are appropriate for small firms. ${ }^{48}$

By the time the Advisory Committee completed its study, there was a new SEC Chairman, Christopher Cox, a former Republican congressman who had been a member of the conference committee on SOX. Chairman Cox expressed no interest in repealing any part of the statute for even a subset of firms. ${ }^{49}$ That position would appear to be informed, at least in part, by a desire to craft a response to calls for relieving the regulatory burden that all of the SEC commissioners would support. It is worth noting that the statutory requirement that no more than three of five commissioners be from the same political party had resulted in the previous two Republican Chairmen's being embroiled in highly divisive partisan votes, which contributed to their failure to retain their positions. ${ }^{50}$ Furthermore, as a legislator, Cox sought bipartisanship, and a hallmark of his leadership at the SEC had been the pursuit of consensual decision-making, even at the cost of stymieing the agenda of some of his political party's core constituents. ${ }^{51}$

45 Id. at $35-36$.

$46 \quad$ Id. at 35.

$47 \quad I d$. at 36.

48 Id. at 124.

49 See infra Part II.B.1 (discussing Cox's rejection of the Committee's recommendation).

50 See, e.g., Lynn Hume, SEC Watchers: Big Changes Possible During President Bush's Second Term, 350 BOND BUYER 36 (Nov. 4, 2004); Michael Schroeder, Accounting-Board Rift Bodes Ill for SEC, WALL ST. J., Oct. 28, 2002, at A4.

51 Duncan Currie, Unmasking Chris Cox, THE AMERICAN (2007), available at http://www.american.com/archive/2007/march-april-magazine-contents/unmasking-chris-cox/. Cox emphasized his legislative reputation for bipartisanship at his confirmation hearing. When asked by Senator Richard Shelby, the Banking Committee Chairman, whether he was troubled by the agency's lack of consensus on significant regulation, Cox stated that he would undertake to build bipartisan consensus if confirmed. Hearing on SEC Nominations Before the S. Comm. on Banking, Housing, and Urban Affairs, 109th Cong. (2005) [hereinafter Nominations Hearing] (statement of Rep. Christopher Cox). 
But it also bears noting that Senator Charles Schumer stated at the confirmation hearing on Cox's nomination as SEC Chairman that he supported the nomination because Cox was "pro-regulation" and had stated both publicly and privately that he would not rollback SOX or other regulations adopted under his predecessor's chairmanship. ${ }^{52}$ Before the hearing, the Senator had expressed reservations regarding Cox's nomination. Thus a private assurance to senators that he would maintain the status quo could explain Cox's rejection of the Advisory Committee's recommendation.

An additional institutional constraint would likely have informed Chairman Cox's reaction to the Committee's recommendations. He would need to obtain the agreement of the other relevant regulator, the $\mathrm{PCAOB}$, and not just consensus among SEC commissioners, to alter successfully section 404's implementation for small firms. Although the PCAOB is appointed by the SEC, it would have been a public relations nightmare were the agency to implement a relaxation of audit standards over the Board's objection, particularly in the environment in which Cox was operating, with the other party (Democrats) in control of Congress, as they could make his life extremely difficult, by calling him in for hearings, requesting information, and investigating agency actions. Indeed, newspapers subsequently reported that officials at the two agencies had disagreed on how to address business' complaints concerning section 404, and implied that the PCAOB had rejected proposals by Cox to exempt some small firms from some aspects of section 404 compliance. $^{53}$

An interview with Chairman Cox held the year following the implementation guidelines' revision bolsters the view that obtaining unanimity among the SEC commissioners would be an insufficient explanation for why Cox opposed revisiting SOX. In that interview, Cox disputed observations that he was driven by consensus, stating, "[t]hat has been oft repeated, but it's not my approach. ${ }^{, 54}$ Only a few months later, there was such a split vote, in which Cox voted with the two Democratic commissioners against the other two Republicans. ${ }^{55}$

$52 \quad$ Nominations Hearing, supra note 51.

53 Carrie Johnson, Deadlock Broken on Revising Audit Rule, WASH. POST, Dec. 6, 2006, at D1.

54 Stephen Labaton, Is the S.E.C. Changing Course?, N.Y. TIMES, Mar. 1, 2007, at Cl.

55 Chairman Cox and the two Democratic commissioners requested the Solicitor General to file a brief in support of the petitioner's position in a Supreme Court case that sought to overturn the Court's precedent and expand private civil securities litigation, which the other two Republican commissioners opposed. It is possible that in abandoning a consensus strategy, the Chairman's vote was a strategic response to a Democrat-controlled Congress that was pressing the agency to support the petitioner's position, since Congress could make his life miserable through its oversight authority. In explaining his vote to Congress, the Chairman emphasized the desirability of maintaining the agency's prior position on the issue to provide "predictability" to the market, although he also stated that his vote was not "reflexively" driven by that precedent. Cox, Atkins, Casey Explain Reasons for Diverging on Scheme Liability Issue, 22 Corp. Counsel Weekly (BNA) 201 (July 4, 2007). Notwithstanding the SEC's request, the Solicitor General filed a brief supporting the respondent, adopting the position 
Chairman Cox's response to the Advisory Committee's recommendation was an announcement that the agency would review the implementation of section 404 to reduce the regulatory burden imposed on all companies and would delay yet again the section's implementation for small and foreign issuers, compliance with the auditor attestation component being further deferred to 2008. The rationale for rejecting the Committee's recommendation and simply postponing compliance for another year was that by then, new guidance would be in place and the provision's regulatory burden would be reduced, making compliance "doable" for smaller firms. ${ }^{56}$ As will be discussed in Part IV, in my judgment, given the post-SOX auditor regulatory regime, it is doubtful that the agency's initiative will in any meaningful way reduce the cost of SOX.

\section{Committee on Capital Markets Regulation}

In contrast to the Advisory Committee's focus on SOX's regulatory burden on smaller firms, the other three commissioned reports were directed at assessing SOX's impact on the global competitiveness of U.S. firms and markets. The first report to appear was an interim report by the Committee on Capital Markets Regulation ("Capital Markets Committee"), a private group formed in September 2006, whose focus was on "maintaining and improving the competitiveness of the U.S. capital markets." ${ }^{, 57}$ It produced a report two months later with the assistance of academic advisors and private financial support.

Although a private-sector entity, the Capital Markets Committee and its report received considerable attention, undoubtedly in no small part because it had a perceived government connection. It was, in fact, often interchangeably referred to as the "Paulson Committee" by the media because in the press release announcing the Committee's formation, Treasury Department Secretary Paulson praised its creation, and one of its co-chairs had served as a top executive under Paulson at Goldman Sachs. In addition, its other co-chair, the Dean of Columbia Business School, informed the news media upon the announcement of the Committee's formation that Secretary Paulson had requested a report by November so that the recommendations "could be considered at post-election meetings of Congress." ${ }^{\text {,58 }}$ Their working assumption

advocated by the Treasury Department, in response to letters by the Federal Reserve Board and the Comptroller of the Currency. Steven Sloan, Cable TV Suit Has Industry Watching, AM. BANKER, June 18,2007 , at 1. The Supreme Court affirmed the decision, upholding the Treasury Department's position. Stoneridge Inv. Partners v. Scientific-Atlanta, Inc., 552 U.S. 148 (2008).

56 See Rachel McTague, SEC Adopts Management Guidance for Evaluating Internal Controls Under SOX, 5 Corp. Accountability Rep. (BNA) 558 (June 1, 2007).

57 COMM. ON CAPITAL MKTS. REG., INTERIM REPORT, at vii (2006), available at http://www.capmktsreg.org/pdfs/11.30Committee_Interim_ReportREV2.pdf. The group consisted of twenty-two individuals from academia, from the investor, business, and financial communities, and from legal and accounting service providers.

58 Floyd Norris, Panel of Executives and Academics To Consider Regulation and Competitiveness, N.Y. TIMES, Sept. 13, 2006, at C3. 
would have been that the Republicans would continue to control Congress, which, as it turned out, did not occur.

The Capital Markets Committee report began by presenting data indicating that the competitive position of U.S. capital markets had significantly eroded: a decline in foreign company initial public offerings (IPOs), an increase in foreign firms' private equity issues, an increase in domestic-going-private transactions and in venture capital exits by private sales rather than IPOs, and a decline in the listing premium for cross-listed foreign firms. It then identified four areas where policy adjustments were needed to address the competitiveness problem, one of which was the implementation of SOX. The report recommended three modifications in section 404's implementation: a redefinition of materiality, increased auditor guidance by the PCAOB to reduce auditors' demands on management, and multi-year rotational testing for low-risk components of internal controls. ${ }^{59}$ As its suggested changes could be accomplished by SEC rule-making, it concluded that there was no need for legislative revision. The report further noted that SEC Chairman Cox reportedly had recommended that the $\mathrm{PCAOB}$ adopt the same revised materiality standard. ${ }^{60}$

The report minimized section 404 as an issue, placing SOX at the bottom of the list of four competitiveness policy areas requiring attention. It instead emphasized the need for private litigation reform, and in particular, capping auditors' liability. It also called for a comprehensive overhaul of the regulatory process, encouraging the SEC and financial market self-regulatory organizations to use cost-benefit analysis in rule-making and to adopt principles-based, rather than prescriptive, rules. Although reducing auditor liability was an independent agenda item, it has a straightforward relation to SOX: because demands of attesting accountants are thought to drive the bulk of section 404 expenditures, reducing auditor liability could also serve to lower the provision's cost by lessening the attesting accountants' incentive to engage in defensive auditing. ${ }^{61}$ It is therefore possible that relegating SOX to the bottom of the agenda was a political calculation by the Committee regarding what modifications to SOX were politically feasible given a new political reality: by the time the report was released, the Committee was aware not only

59 COMM. ON CAPITAL MKTS. REG., supra note 57, at 19-20.

$60 \quad I d$. at 19.

61 To be sure, concerns about auditor liability and the impact of litigation on U.S. firms' competitiveness predate SOX, see, for example, Sanjai Bhagat \& Roberta Romano, Event Studies and the Law: Part I: Technique and Corporate Litigation, 4 AM. L. \& ECON. REV. 141, 153 (2002), and would remain even were section 404 repealed in entirety. It should be noted that the Committee's ordering of priorities placed third, and above revising SOX, increasing "shareholder rights." Here, the Committee advocated adoption of many policies sought by activist public pension and labor union funds in proxy proposals on takeover defenses and director elections, along with a proposal those organizations would most certainly not endorse: replacing shareholder litigation with arbitration. Given the grab bag of proposals, the Committee appears to have been seeking to forge a political compromise that would offer something to everyone, within an overarching goal of reducing the regulatory cost of business activity. 
of Chairman Cox's opposition to legislative revision of SOX, but also that the Democrats would control Congress. Advocating fine tuning SOX through agency rulemaking was regulatory relief that the Republican administration could accomplish on its own.

Although the Capital Markets Committee flatly rejected the Advisory Committee's call for small-firm exemptive relief, it added a caveat. If, after adopting the report's proposed modifications, the SEC were to find that compliance with 404 was still too burdensome for small companies, then the SEC was advised to seek legislation to exempt those firms from the auditor attestation requirement. ${ }^{62}$ The Committee took a less diffident tack, however, to foreign firms' compliance problems. It advocated exempting foreign firms from section 404 if they were subject to equivalent home-state regulation of internal controls.

A plausible inference from the lack of parallelism in approach to small domestic versus foreign firms is that the Committee regarded SOX's impact on capital-market competitiveness to be more severe than its effect on small firms. But a more compelling explanation for the difference in approach goes to the rationale for the Committee's formation: the need to improve the competitiveness of capital markets, a principal concern of the stock markets and financial centers. ${ }^{63}$ That definition places front and center the agenda of a different constituency, the stock exchanges, in contrast to that of the Advisory Committee, small firms. In support of this contention is the fact that the Committee's recommendation regarding foreign firms resembles a longstanding position advocated by the New York Stock Exchange (NYSE), that foreign issuers should be governed by home regulators, with the expectation that it would improve the NYSE's market position against its principal competitor, the London Stock Exchange, by reducing the regulatory cost of foreign firms' listing in the United States. ${ }^{64}$

\section{McKinsey \& Company Study for Senator Schumer and Mayor Bloomberg}

At approximately the same time as the Capital Markets Committee was being formed, New York Senator Charles Schumer and New York City Mayor Michael Bloomberg commissioned a study under the auspices of the city's Economic Development Corporation from the consulting firm McKinsey \& Company to ascertain why foreign firms were increasingly raising capital outside of New York (the "McKinsey Study"). McKinsey surveyed executive, investor, consumer, and labor group representatives, and experts in the regulatory, legal, and accounting professions. The McKinsey Study, which is often referred to in press accounts as the "Schumer-Bloomberg Study," was

62 COMM. ON CAPITAL MKTS. REG., supra note 57, at 20.

63 Id. at ix.

64 See, e.g., James L. Cochrane, Are U.S. Regulatory Requirements for Foreign Firms Appropriate?, 17 FORDHAM INT'L L.J. S58 (1994). 
released at a January 2007 news conference at New York's City Hall, attended by both Senator Schumer and Mayor Bloomberg, and by the newly-elected Governor, Eliot Spitzer.

The McKinsey Study mirrored the Capital Markets Committee report's diagnosis of the problem: it reviewed data indicating declining U.S. capitalmarket competitiveness and highlighted SOX and litigation as threatening New York City's preeminence as a financial center. ${ }^{65}$ No doubt, given its sponsorship by elected officials, the study was intended to advance an important political objective, that of dramatizing the relative deteriorating condition of a major contributor to New York's economy, and thereby mobilizing support for concerted government action at the local, state, and federal levels to rectify the situation.

The McKinsey Study's solution likewise mirrored the recommendations of the Capital Markets Committee: modifications in the implementation of section 404 to provide clearer guidance, including a revised definition of materiality, and a "top-down" (that is, management-, not auditor-controlled) "risk-based" approach. It differed from the Capital Markets Committee in one important respect regarding the qualification offered for small firms' treatment: the McKinsey Study recommended that the SEC consider permitting small firms to opt out of section 404 entirely with disclosure of this choice to investors, if the agency's proposed guidance did not lower small firms' compliance costs. ${ }^{66}$ It also recommended that the agency consider exempting foreign firms that complied with foreign regulatory regimes receiving SEC approval, paralleling the Capital Market Committee's position. But in contrast to the Capital Market Committee's report, the McKinsey Study placed amending SOX at the top of the policy agenda, in a list of items characterized as "critically important near-term national priorities." ${ }^{\text {,67 }}$ Litigation reform was second in the list of priorities, with recommendations to cap the liability of auditors and of foreign firms in proportion to their exposure to the U.S. market, and to promote arbitration in place of securities litigation.

With regard to the recommendation concerning revising SOX, at the press conference held to announce the study's findings, Senator Schumer stated that the strategy was to take an administrative, rather than legislative, route, because the proposed changes could all be accomplished by SEC rulemaking, without

65 In addition to the market trends noted earlier regarding IPOs and foreign listings, the study described three additional indicators of a competitiveness problem. European investment banking, sales, and trading revenues had risen almost to parity with those in the United States; a larger over-the-counter derivatives market had developed in Europe than in New York; and U.S. financial stock grew at a lower rate than that of other regions. MCKINSEY \& CO., SUSTAINING NEW YORK'S AND THE UNITED STATES' GLOBAL FINANCIAL SERVICES LEADERSHIP 9-14 (2007), available at http://www.senate.gov/ -schumer/ SchumerWebsite/pressroom/special_reports/2007/NY_REPORT\%20FINAL.pdf.

66 Id. at $19-20$.

67 Id. at 96-97. 
congressional action. ${ }^{68}$ That was so because the Study's principal recommendation on SOX was in accord with action the SEC had initiated in response to the Advisory Committee's report, the process of revising guidance on section 404 compliance. $^{69}$

\section{Commission on the Regulation of U.S. Capital Markets in the 21 st Century}

In February 2006, the Chamber of Commerce created a commission, the Commission on the Regulation of U.S. Capital Markets in the 21st Century ("Chamber Commission"), to study capital-market competitiveness, out of concern over U.S. exchanges' declining share of global capital-market transactions. The Chamber Commission understood its charge as to recommend the correct balance for capital-market regulation between the competing statutory goals to promote capital formation and to protect investors. ${ }^{\circ}$ Although established well before the Capital Markets Committee's formation and the commissioning of the McKinsey Study, the Chamber Commission's report was released after their reports, in March 2007. The Chamber Commission spent over a year developing its report. ${ }^{71}$ It followed the Advisory Committee's format of holding public hearings, no doubt to generate increased public awareness of the issue, and it also met with regulators and government officials.

68 Greg Morcroft \& Robert Schroeder, New York as Financial Center Seen Threatened, MARKETWATCH, Jan. 22, 2007, http://www.marketwatch.com/story/new-york-as-financial-center-seenunder-threat (last visited June 9, 2009).

69 Proposed interpretive guidance had been issued by a unanimous SEC in December that included in its purview a risk-based assessment approach and a revised definition of materiality that was also to be adopted by the PCAOB. Management's Report on Internal Control over Financial Reporting, 71 Fed. Reg. 77,635, 77,640-48 (Dec. 27, 2006). That release also included a proposed change to the rules implementing section 404, which stated that a management internal control evaluation which followed the steps in the interpretive guidance would be deemed to satisfy section 404's implementation rules. The McKinsey Study's recommendations did diverge from the SEC's proposed guidance in one noteworthy respect: it criticized the proposed revised definition of materiality, despite the definition's tracking of the Capital Markets Committee's suggested drafting. MCKINSEY \& Co., supra note 65, at 98. The Study's objection was in keeping with criticism expressed by the corporate bar that the revised definition would not reduce compliance costs because it would not alter auditors' incentive to classify insignificant or technical control breaches as material due to liability concerns. See, e.g., James Hamilton, Proposed Definition of Material Weakness May Not Help Lower Internal Control Costs, http://www.business.cch.com/securitiesLaw/news/05-04-07e.asp (last visited June 9, 2009).

70 COMM'N ON THE REgULATION OF U.S. CAPITAL MKTS. IN THE 21ST CENTURY, REPORT AND RECOMMENDATIONS 6-7 (2007), available at http://www.capitalmarketscommission.com/portal/ capmarkets/default.htm (follow "Download the full report" hyperlink).

71 At least one local chamber of commerce undertook its own study without waiting for the national Commission's report. The Greater Boston Chamber of Commerce released a study in March 2006 that advocated revising SOX compliance requirements for small firms, emphasizing that SOX compliance costs significantly burdened small firms, such as biotechnology and life sciences firms. Chris Reidy, Study: Sarbanes-Oxley Costs Burden Small Firms, Boston GLOBE, Mar. 1, 2006, at C4. On releasing the study, the Boston Chamber reported that it was endorsed by chambers in other locations with a substantial presence of high-tech companies, such as San Francisco, California and Raleigh, North Carolina. Id. 
The Chamber Commission advocated legislation incorporating SOX into the Securities Exchange Act of 1934, in order to clarify that the SEC's exemptive power is applicable to SOX section 404-authority that might otherwise appear to be in question. ${ }^{72}$ It advanced this approach as a mechanism to provide flexibility for the agency's implementation of SOX, so that it could vary section 404's requirements for different sized firms and exempt foreign firms. ${ }^{73}$ Notwithstanding the directive to focus on market competitiveness, the Chamber Commission's recommendation meshes better with the Advisory Committee's agenda rather than that of either the Capital Markets Committee or the McKinsey Study, whose solutions minimize a need to tailor requirements for small firms. Advocacy of an approach permitting flexibility in small firms' regulation is consistent with the Chamber's policy position when SOX was moving through the legislative process: the Chamber lobbied at the time for small firms' exemption from provisions restricting auditor services. ${ }^{74}$

To promote its agenda, which also called for dramatic reorganization of the SEC, in conjunction with the report's release the Chamber held a summit, which was attended by SEC Chairman Cox and members of Congress. In a speech delivered at that meeting, Chairman Cox flatly rejected the Chamber Commission's recommendation regarding SOX, stating "We don't need to change the law; we need to change the way the law is implemented, [and] the SEC has all the power and flexibility we need." 75 The key Democratic lawmakers present (the chairmen of the committees with jurisdiction over the SEC) concurred with that judgment. ${ }^{76}$

In particular, Congressman Barney Frank, the Chairman of the House Financial Services Committee, which has jurisdiction over securities regulation, was more circumspect in his remarks than the SEC Chairman. Congressman Frank stated that "Everyone agrees that we should have Sarbanes-Oxley somewhat diminished" and that "if legislative changes are needed to improve section 404 , you can have them." of his statements was that "If [the SEC] need[s] more legislative authority, [it] should ask us." 78 Congressman Frank would have been well aware that

72 Some legal scholars have contended that the SEC's exemptive authority under section 36 of the 1934 Act, 15 U.S.C. $\$ 78 \mathrm{~mm}$ (2006), is inapplicable to section 404 because Congress did not cast that provision as an amendment to the 1934 Act. See, e.g., James D. Cox, Comment to the SEC on the Exposure Draft of Final Report of Advisory Committee on Smaller Public Companies, 71 Fed. Reg. 11,090 (Mar. 21, 2006), available at http://www.sec.gov/rules/other/265-23/26523-309.pdf.

73 COMM'N ON THE REGULATION OF U.S. CAPITAL MKTS., supra note 70, at 7.

74 Romano, supra note 15 , at 1565.

75 Rachel McTague \& Richard Hill, Cox Opposes Call for SOX Exemptions: Dodd Says Market Concerns Are Premature, 5 Corp. Accountability Rep. (BNA) 266 (Mar. 16, 2007).

76 Id.

77 Id.

78 Id. 
Chairman Cox would not be knocking on his door, which suggests that his remarks were less than candid. ${ }^{79}$

The reaction of Senator Christopher Dodd, Chairman of the Senate Banking Committee, would appear to have been even less receptive to consideration of legislative relief than that of Congressman Frank. Not only did the Senator deny that competitiveness was a pressing matter, but he also cautioned against trying to compete with "growing" foreign markets and engaging in a "regulatory race to the bottom" that "jettison[ed] ... [our] legal protections." ${ }^{, 80}$ Senator Dodd did, however, express approval of the SEC's reexamination of SOX's implementation. A legal service reporter offered the following perspective on Senator Dodd: he would not tamper with SOX in "deference to ... his close colleague," Senator Sarbanes. ${ }^{81}$ That interpretation of the Senator's decision-making is plausible, as is the not mutually exclusive, if not more compelling, explanation that maintaining the status quo on SOX would be entirely consistent with his own policy preference: not only has Senator Dodd associated himself with the statute, but also his voting record, although not quite as liberal as that of Senator Sarbanes, is slightly to the left of the median Democrat, as measured by a widely-adopted score from congressional roll-call voting. ${ }^{82}$

A factor that surely also informed the two committee chairs' reactions was the introduction in both chambers a few days earlier of bills that would have revised the implementation rules for section 404 and permitted small firms to opt out of its requirements. The House bill had both a Democrat and Republican sponsor, but the Senate bill did not. ${ }^{83}$ Senator Dodd would quite reasonably have thought there to be a negligible chance of any legislative pressure on him to alter his position, because with only one Republican cosponsor of the Senate bill and Democratic control of the chamber, the

79 One legal service concluded from this statement that it was "unclear" whether he would defer to Cox regarding the need for legislation. Hill Watch, 39 Sec. Reg. \& L. Rep. (BNA) 569 (Apr. 9 , 2007). The inference is odd, however. In earlier interviews, Congressman Frank indicated that he "ha[d] no interest in rewriting the law" and wanted the SEC "to figure out" how to interpret it less restrictively for small firms. Steven Syre, Market Cops Taking Heat, Boston GLoBE, Nov. 30, 2006, at D1. In fact, when the House voted to extend for an additional year the deferred application of section 404 to small firms in June 2007, Frank opposed the extension, referring to Chairman Cox's statement that legislation was unnecessary, 153 CONG. REC. H7324 (daily ed. June 27, 2007). Such a position is utterly at odds with the legal service's assertion that the Congressman might support legislation to relax the regulation against the agency's wishes.

80 McTague \& Hill, supra note 75.

81 Hill Watch, supra note 79.

82 Senator Dodd takes credit for the statute on his website: "I'm proud to have helped author this vital legislation...." Christopher Dodd, Statement of Senator Dodd on the 5th Anniversary of the Enactment of Sarbanes-Oxley (July 30, 2007), http://dodd.senate.gov/index.php?q=node/3998. For the 107 th Congress in which SOX was enacted, Senator Dodd's DW-NOMINATE score was -.397 whereas that of Senator Sarbanes was -.555. See supra note 16.

83 The Senate bill was introduced on March 14, only a day or so before Senator Dodd's remarks at the Chamber's event; the cosponsor, but not the sponsor, was a member of the Banking Committee. The bill's second, and only other, cosponsor, also a Republican, signed on a few days afterward. 
probability that the bill could gain any traction would have appeared extremely remote. Such a conjecture would be consistent with the political science literature's characterization of congressional cosponsorship as a signal of coalition building. That literature has found that the probability of a bill moving forward in the legislative process is a function of the number of cosponsors and the proportion of sponsors on the committee with jurisdiction, although neither variable significantly impacts enactment. ${ }^{84}$

In addition, as Banking Committee Chairman, Senator Dodd was well positioned to block SEC-related bills that he did not support from reaching the floor. Although political scientists have noted that a committee's gate-keeping function is difficult to sustain when a legislative majority desires action, ${ }^{85}$ such an outcome would have seemed far-fetched to any reasonably informed observer at the time the Senator made his remarks. Finally, the SEC Chairman's action plan would have provided Senator Dodd with a credible explanation for his legislative indifference on a matter of importance to potentially disgruntled constituents. ${ }^{86}$ Moreover, as discussed in Part II, six weeks later it would prove to be useful for positioning the issue on the Senate floor.

\section{The Empirical Literature on SOX and Its Relationship to the Reports' Critiques}

The commissioned reports' questioning of the wisdom of SOX echo the thrust of the empirical research on SOX's impact on capital markets and firms. The following U.S. capital-market trends post-SOX, emphasized in varying degrees by the reports, have been identified in the academic literature: (1) a decrease in new foreign listings, ${ }^{87}(2)$ a decline in IPOs, ${ }^{88}(3)$ an increase in

84 See, e.g., Rick K. Wilson \& Cheryl D. Young, Cosponsorship in the U.S. Congress, 22 LEG. STUD. Q. 25 (1997). Although Congressman Frank did not use the SEC's position as a shield as did Senator Dodd, the calculation regarding the House bill's prospects would not differ significantly from that of the Senate, in view of that literature. A plausible explanation why Frank did not feel a need to invoke the SEC's action for framing his position, compared to Senator Dodd, is that the majority party generally exercises strict control over legislation in the House, in contrast to the Senate. SMITH ET AL., supra note 10 , at 234.

85 See, e.g., Keith Krehbiel, Why Are Congressional Committees Powerful?, 81 AM. POL. SCI. REV. 929 (1987); Kenneth A. Shepsle \& Barry R. Weingast, Why Are Congressional Committees Powerful?, 81 AM. POL. SCI. REV. 935 (1987).

86 In his landmark study of Congress, Richard Fenno notes that for the vast majority of votes, legislators are not constrained by constituent preferences and can vote "as they wish," provided that they can satisfactorily explain their votes to constituents. RICHARD F. FENNO, JR., HOME STYLE: HOUSE MEMBERS IN THEIR DISTRICTS 151 (1978). Senator Dodd's response was, to be sure, a meager answer to the problem as perceived by the business community. Yet it still provided the Senator with a plausible explanation of his position: he was voicing support for the position of the agency's Republican Chairman, who was considered to be sympathetic to business' concerns and who ostensibly was seeking to address the issue.

87 E.g., Craig Doidge, George Andrew Karolyi \& Rene M. Stulz, Has New York Become Less Competitive in Global Markets? Evaluating Foreign Listing Choices over Time, 91 J. FIN. ECON. 253 
going-private transactions; ${ }^{89}$ and (4) an increase in firms going "dark," that is, deregistering but not eliminating all public shareholders. ${ }^{90} \mathrm{~A}$ further finding related to the second and third trends but not mentioned in the reports is that, post-SOX, in order to realize growth opportunities, there appears to have been an increase in small firms being sold to private firms, rather than to public ones. ${ }^{91}$

In addition, both empirical research and survey data document an increase in director costs and audit fees post-SOX, particularly for small firms, and correspondingly, an increased cost of being public post-SOX.$^{92}$ For example, James Linck, Jeffrey Netter, and Tina Yang find a large increase in total director compensation for small firms in the interval around SOX (from 2001 to 2004), going from $\$ 2.35$ to $\$ 3.19$ per $\$ 1000$ sales (a $36 \%$ increase). ${ }^{93}$ Furthermore, Peter Iliev compared firms at the threshold of having to comply with section 404 to those firms that stay just below the threshold. He finds that audit fees are more than double for compliant firms at $\$ 800,000$, compared to fees of $\$ 370,000$ for firms that did not have to comply. ${ }^{94}$ Additional evidence that SOX's cost does not outweigh the benefits for small firms is several studies' finding that small firms appear to deliberately avoid coming under section 404 by maintaining their market capitalization and revenues below the threshold..$^{95}$ Moreover, although the findings of event studies of the impact of

(2009); Joseph D. Piotroski \& Suraj Srinivasan, Regulation and Bonding: The Sarbanes-Oxley Act and the Flow of International Listings, 46 J. ACCT. RES. 383 (2008).

88 E.g., Luigi Zingales, Is the U.S. Capital Market Losing Its Competitive Edge? (Eur. Corp. Governance Inst., Finance Working Paper No. 192/2007, 2007).

89 E.g., Stanley B. Block, The Latest Movement to Going Private: An Empirical Study, J. APPLIED FIN., Spring/Summer 2004, at 36; Ellen Engel, Rachel M. Hayes \& Xue Wang, The SarbanesOxley Act and Firms' Going-Private Decisions, 44 J. ACCT. \& ECON. 116 (2007); Ehud Kamar, Pinar Karaca-Mandic \& Eric Tally, Going-Private Decisions and the Sarbanes-Oxley Act of 2002: A CrossCountry Analysis (Rand Working Paper No. WR-300-2-EMKF, 2008).

90 Christian Leuz, Alexander Triantis \& Tracy Yue Wang, Why Do Firms Go Dark? Causes and Economic Consequences of Voluntary SEC Deregistrations, 45 J. ACCT. \& ECON. 181 (2008).

91 Kamar et al., supra note 89.

92 Peter Iliev, The Effect of the Sarbanes-Oxley Act (Section 404) (2007) (unpublished manuscript), available at http://ssm.com/abstract $=983772$; Linck et al., supra note 41 ; FOLEY \& LARDNeR LLP, THE COST OF BEING PUBliC IN THE ERA OF SARBanes-OXLey (2006) (survey), http://www.foley.com/files/tbl_s31Publications/FileUpload137/3420/ndi\%202006\%20public\%20study \%20FINAL.pdf; see William J. Carney, The Costs of Being Public After Sarbanes-Oxley: The Irony of "Going Private," 55 EMORY L.J. 141 (2006) (reviewing estimates of increased cost of being a public company post-SOX, and data on increased going-private transactions); Christoph Kaserer, Alfred Mettler \& Stefan Obernberger, Has the Sarbanes-Oxley Act Reduced the Adverse Selection Cost of Going Public? (2008) (unpublished manuscript), available at http://ssrn.com/abstract=1147138 (finding legal and audit fees for small firm IPOs significantly increased post-SOX and total flotation costs decreased post-SOX for large firms but not for small firms).

93 Linck et al., supra note 41.

94 Iliev, supra note 92; see also Linck et al., supra note 41. Iliev's finding is consistent with Block's estimate that the cost of being a public company more than doubled post-SOX from $\$ 900,000$ to $\$ 1.95$ million. The SEC Advisory Committee reported that external audit fees tripled as a percentage of revenue over the period 2000 to 2004 , surrounding the adoption of SOX.

95 Feng Gao, Joanna Shuang We \& Jerold L. Zimmerman, Unintended Consequences of Granting Small Firms Exemptions from Securities Regulation: Evidence from the Sarbanes-Oxley Act, 47 J. ACCT. RES. 459 (2009); Iliev, supra note 92; Maria E. Nondorf, Zvi Singer \& Haifeng You, A 
the statute's enactment on stock prices conflict-depending on the event dates selected, there was either a positive or negative price effect ${ }^{96}$ - when the price effects for small firms are separately analyzed, the studies find that those firms experienced negative price effects. ${ }^{97}$ This suggests that regardless of the selection of event dates, at least for small firms investors anticipated that SOX would impose a disproportionately high cost, incommensurate with the benefits.

Neither the post-SOX market trends nor the disproportionate cost burden of SOX on small firms is disputed in the literature. Rather, what is at issue in the literature is whether the observed capital-market trends are attributable to SOX or to unrelated, contemporaneous factors, such as improvements in the trading quality provided by foreign exchanges. ${ }^{98}$ For example, Craig Doidge, Andrew Karolyi, and Rene Stulz contend that the post-SOX decline in U.S. listings relative to U.K. listings is not due to SOX, because the U.K. listings' increase consists of small, riskier firms listing on London's Alternative Investment Market (AIM) that would not be able to list on the NYSE. ${ }^{99}$ Other studies, however, identify SOX as contributing to the decline in new listings. ${ }^{100}$

One approach for arbitrating the competing assessments is by reference to the results in the literature that examines the effect of SOX on cross-listed firms. To the extent that those firms are adversely affected by the statute, it

Study of Firms Surrounding the Threshold of Sarbanes-Oxley Section 404 Compliance (2007) (unpublished manuscript), available at $\mathrm{http}: / / \mathrm{ssm}$.com/abstract $=1004965$.

96 For a summary and assessment of the three leading event studies of SOX, see Kenneth Lehn, Sarbanes-Oxley: A Review of the Empirical Evidence and a Proposal for Reform 11-13 (Apr. 8, 2008), http://www.frbatlanta.org/news/CONFEREN/08FMC/08FMC_lehn.pdf. Lehn concludes that the selection of event dates is most appropriate in the study by Zhang that finds a cumulative negative stock price effect, because it includes earlier events on which information was released regarding the probability legislation would pass than the two studies finding positive price effects. By not including all relevant dates, the latter studies' positive finding could therefore plausibly be an indication that the market had determined the final version was less costly than initially anticipated. Id. at 13 .

97 E.g., Vidhi Chhaochharia \& Yaniv Grinstein, Corporate Governance and Firm Value: The Impact of the 2002 Governance Rules, 62 J. FIN. 1789 (2007); M. Babajide Wintoki, Corporate Boards and Regulation: The Effect of the Sarbanes-Oxley Act and the Exchange Listing Requirements on Firm Value, 13 J. CORP. FIN. 229 (2007).

98 There is no debate in the literature over whether SOX is the source of disproportionately higher compliance costs for small firms; there is simply normative disagreement concerning whether those costs justify exempting small firms from the statutory requirements, or otherwise reducing the scope of their compliance. Given that SOX's disproportionate impact on small firms' compliance costs is not an empirically disputed issue, the remainder of this Section is addressed to the literature on SOX's impact on market competitiveness.

99 Doidge et al., supra note 87

100 E.g., Zingales, supra note 88. Piotroski and Srinivasan compare foreign (non-U.S. and non-U.K.) firms' listing choices between U.S. and U.K. exchanges, to focus on the listing choice given that a firm selects a high quality exchange, thereby better controlling for the impact of SOX. Piotroski \& Srinivasan, supra note 87 (small firms). They find that the probability of small firms listing in the United States declined post-SOX. Their findings differ from those of Doidge and his co-authors, supra note 87, who also compare U.S. and U.K. foreign listings, because they examine both large and small firms, whereas Doidge and his co-authors examine only large firms. Piotroski and Srinivasan find that Doidge and his co-authors' result holds up only for large firms, whose listing choices were unchanged by SOX. 
suggests that SOX does indeed impact the calculation of foreign firms regarding listing and delisting on U.S. exchanges post-SOX. ${ }^{101}$ There are two strands in the literature on SOX and cross-listed firms: one set of papers examines the stock price effects on foreign firms of events related to the statute's enactment, while the other investigates the post-SOX value of the historic market premium accorded cross-listed stocks. ${ }^{102}$

The most comprehensive studies of those effects of SOX on foreign firms have been undertaken by Kate Litvak, who uses a difference-in-difference approach comparing cross-listed firms with matched non-cross-listed firms, similar in size and industry, from the same country. ${ }^{103}$ She finds that the stock price reactions of the paired firms differ significantly, and that the cross-listed firms were negatively affected by SOX. ${ }^{104}$ She also finds that the cross-listing premium has declined significantly post-SOX, with the decline larger for crosslisted firms required to comply with the statute. ${ }^{105}$ These data suggest that SOX negatively impacted foreign firms, and are consistent with interpreting the decline in foreign listings as related to SOX.

A shortcoming of studies of listing trends that reject SOX as a cause of the relative decline in U.S. market share of foreign firms is that they focus solely on large firms and do not distinguish across firms by size. ${ }^{106}$ When foreign firms' choices are separately analyzed by firm size, the studies find that SOX affected the listing decisions of small firms: those firms were more likely

101 As Piotroski and Srinivasan note, listing decisions of foreign firms are a "good indicator" of a specific markets' costs and benefits because those firms can choose from a "wide range of competing alternatives." Piotroski \& Srinivasan, supra note 87, at 384.

102 Several researchers have found that cross-listing on a U.S. exchange is related to higher market-to-book ratios, indicating that firms obtain a premium for cross-listing. Lehn, supra note 96 , at 16-17. One explanation of the effect is that the firms are "bonding" themselves to comply with higher U.S. governance and disclosure standards, which investors interpret positively. Zingales, supra note 88, at $10-14$.

103 Kate Litvak, The Effect of the Sarbanes-Oxley Act on Non-U.S. Companies Cross-listed in the U.S., 13 J. CORP. FIN. 195 (2007) [hereinafter Litvak, Non-U.S. Companies]; Kate Litvak, The Longterm Effect of the Sarbanes-Oxley Act on Cross-listing Premia, 14 EuR. FIN. MGMT. 875 (2008) [hereinafter Litvak, Premia].

104 Litvak, Non-U.S. Companies, supra note 103. Xi Li also finds that cross-listed firms, especially those that would have to comply with the statute, were negatively affected by the enactment of SOX. Xi Li, The Sarbanes Oxley Act and Cross-Listed Foreign Private Issuers (Jan. 18, 2007) (unpublished manuscript), available at http://ssm.com/abstract=952433. He further finds that foreign firms delisting post-SOX experience positive stock returns, in contrast to the negative returns experienced by foreign firms delisting pre-SOX.

105 Litvak, Premia, supra note 103. Using non-paired samples, Zingales, supra note 88 , also finds a decline in the cross-listing premium post-SOX, while Doidge and his co-authors, supra note 87, using a longer pre-SOX period than Zingales, do not. There is, however, no compelling reason why the comparative pre-SOX period should be the ten-year period beginning in 1990 that Doidge and his coauthors select, rather than the five-year period selected by Zingales, which had the advantage of being a more comparable time period to the post-SOX period under study. Both papers use the same post-SOX period, 2003 to 2005.

106 E.g., Doidge et al., supra note 87. 
to list in the United Kingdom after SOX. ${ }^{107}$ SOX also had a negative impact on small U.S. firms' listings. ${ }^{108}$

SOX, accordingly, adversely affected U.S. exchanges through the loss of small-firm listings. The contraction in investing opportunities has, no doubt, adversely affected U.S. investors as well, as they would have to bear currency risk and the other transaction costs of investing abroad rather than domestically in order to invest in such firms. In sum, a fair reading of the empirical literature investigating U.S. capital-market competitiveness post-SOX indicates, at a minimum, that the statute has negatively impacted the stock exchanges' competitiveness due to losses of small-firm listings. Those are also the firms that have been shown to encounter the greatest proportionate operating cost increase due to SOX, in the literature documenting the changing cost of being a public company post-enactment.

\section{The Media and Congress Respond to SOX's Consequences}

Corporate scandals can make good copy for the media, and the media frenzy surrounding the 2001-2002 corporate accounting scandals most surely helped fuel the political dynamic that produced SOX. One measure for gauging the political climate for revisiting SOX is the frequency of news coverage of the legislation's critiques, such as the concerns expressed in the commissioned reports over SOX's impact on small firms and market competitiveness. This approach is informed by a political science literature finding, across policy and geographical space, that legislators and agency officials respond to issues whose salience is heightened by the media.

\section{A. The Relation Between the Media, Issue Saliency, and Public Policy}

A theoretical and empirical literature examining the relation between media coverage and government policies suggests that the media can and does influence policy outcomes by affecting an issue's salience. That thesis is derived from agency models in which citizen-principals are imperfectly informed about actions of their agents (elected officials and civil servants). In

107 Piotroski \& Srinivasan, supra note 87. Of course, the studies only examine foreign firms that have listed on an exchange; if firms choose not to list on a U.S. exchange or undertake private placements in order to avoid SOX, the studies will underestimate the statute's deleterious effect. Because large firms' listing choices appear not to be similarly affected, Piotroski and Srinivasan note that the economic significance or long-run economic impact of the loss of small firms is an "open question." Piotroski \& Srinivasan, supra note 87, at 419.

108 Studies finding small domestic firms' probability of delisting increased post-SOX are Engel et al., supra note 89; Leuz et al., supra note 90; and Kamar et al., supra note 89 (examining firms exiting the public market by means of acquisitions). In addition, Robert Bartlett finds that a greater number of small firms going private post-SOX did not maintain public debt, which would have continued to subject them to securities regulation, including section 404 , than did so pre-SOX. The reverse was true for large firms. Robert Bartlett, Going Private but Staying Public: Reexamining the Effect of Sarbanes-Oxley on Firms' Going Private Decisions, 76 U. CHI. L. REV. 7 (2009). 
the models' setup, the news media provides information that alters an issue's salience and thereby facilitates citizen monitoring, resulting in the government's adoption of policies that citizens prefer. ${ }^{109}$ There are also models in which news coverage of elected officials' positions affects both election and policy outcomes by shifting the salient issues in an election, as politicians focused on reelection adopt policies preferred by voters. ${ }^{110}$

Empirical studies lend credence to the models' plausibility, finding a significant correlation between issue saliency in the media (proxied by, for example, newspaper circulation or article word counts) and the implementation of government policies, or election outcomes. ${ }^{111}$ Moreover, the relation identified in the studies between issue salience and policy and election outcomes is robust, controlling for factors known to affect outcomes.

One of the more relevant studies examining the relation between media salience and public policy finds that Indian state governments increase public food distribution in response to shocks in food production caused by droughts or floods, the higher the regional language newspaper circulation (as opposed to that of national newspapers written in Hindi or English), as well as the higher the level of voter turnout and of political competition. ${ }^{12}$ The study considers regional language newspapers to be a proxy for issue salience, because they are most likely to report on local conditions and to be read by local citizens, as compared to national newspapers. The study characterizes the channel from the media to public policy - here, food distribution-in terms of the electoral connection: by informing the public of social protection problems-droughts and floods-the media increases politicians' incentive to respond out of concern for "their election chances," as responsive officials are more likely to be reelected. ${ }^{113}$ Hence, by increasing the salience of an issue, the

109 Timothy Besley, Robin Burgess \& Andrea Prat, Mass Media and Political Accountability, in World BANK, THE Right To Tell: THE Role of MASS MEDIA IN ECONOMIC DEVELOPMENT 45 (2002); see also KEN KOLLMAN, OUTSIDE LOBBYING PUBLIC OPINION \& INTEREST GROUP STRATEGIES (1998) (proposing a signaling model in which interest groups use the media and other strategies to mobilize constituents in order to demonstrate an issue's salience to policymakers).

110 Besley et al., supra note 109.

111 For example, Andrew Yates and Richard Stroup find that the U.S. Environmental Protection Agency (EPA) is more likely to cancel a chemical's use as a pesticide when there is greater news coverage about the chemical, controlling for the chemical's actual risk as well as interest-group lobbying over the chemical's registration. Andrew J. Yates \& Richard L. Stroup, Media Coverage and EPA Pesticide Decisions, 102 PUB. CHOICE 297 (2000). In Yates and Stroup's model of agency decision-making, media coverage increases issue salience and affects public opinion, which creates pressure on the agency to respond to politicians who want to be on the right side of a salient issue from their constituents' perspective. In addition, Claudio Ferraz and Federico Finan find that Brazilian mayors identified as corrupt by pre-election random audits by the national government are more likely to lose re-election campaigns when there is a local radio station, which can transmit the news to voters. Claudio Ferraz \& Federico Finan, Exposing Corrupt Politicians: The Effect of Brazil's Publicly Released Audits on Electoral Outcomes, 123 Q.J. ECON. 703 (2008). The implication of these studies for SOX is that the SEC and members of Congress would be more likely to revisit SOX as salience concerning its cost increases, particularly prior to an election campaign.

112 Timothy Besley \& Robin Burgess, The Political Economy of Government Responsiveness: Theory and Evidence from India, 117 Q.J. ECON. 1415 (2002).

$113 \quad$ Id. at 1446. 
media affects policymaking as well as election outcomes and thereby renders government more accountable to the citizenry.

Studies of local media coverage of members of Congress suggest that a similar dynamic is at work in the United States as the one identified in the study of Indian state elections. Congressional staffers report that they hear from constituents more often on issues mentioned in the local media than issues that are not. In addition, greater local media election coverage increases citizens' awareness of candidates' positions. ${ }^{114}$ Furthermore, in areas with greater media coverage of congressmen - areas where more of a newspaper's subscribers are within one congressional district-voters are not only more informed about their representatives, but also more likely to vote, and, correspondingly, their congressmen are more likely to pursue constituents' interest, in that they are less likely to engage in partisan voting, and more federal money flows into their districts. ${ }^{115}$

Analogous to droughts and floods in India, SOX can plausibly be characterized, for small firms especially, as an exogenous shock that imposed large unexpected costs on doing business as a public company. Because small firms are ubiquitous, such an adverse impact of SOX would implicate important local economic concerns, whose coverage in local media could impact electoral outcomes. The India and congressional coverage case studies further suggest that there could well be a differential effect on legislators' responsiveness from coverage by regional versus national newspapers of SOX's adverse impact. For instance, a legislative or regulatory response should be more probable if regional or local, rather than national, newspapers carry SOX stories related to small-firm costs.

A cautionary note is, however, in order regarding the efficacy of the policy outcome to be expected from the heightened salience of SOX, which goes to the heart of the rationale for democratic governance. It does not necessarily follow that the media's placing SOX critiques in the public spotlight will cause the legislation to be revamped for the better. In the business regulation context, salience can be a double-edged sword. For instance, to the extent that the public feels antipathy toward private enterprise or individuals of means, or is poorly informed about the workings of the economy, ${ }^{116}$ salience

114 R. DOUglas ARnold, CONGRESS, THE PRESS, AND POLITICAL ACCOUNTABILITY 229-31, 239-40 (2004); DANiElle Vinson, Local MEDia COVERAGE OF CONGRESS AND ITS MEMBERS THROUGH LOCAL EYES 174 (2003).

115 James M. Snyder, Jr. \& David Strömberg, Press Coverage and Political Accountability 29 (Nat'l Bureau of Econ. Research, Working Paper No. 13878, 2008), available at http://www.nber.org/papers/w13878. The measure relating a newspaper's circulation to the boundaries of a congressional district is referred to as its "congruence"; partisan voting measurements involve comparisons of the representatives' DW-NOMINATE scores, see supra note 25 , to the party's vote share in the district and alternatively by how frequently the representative votes with the majority of his or her party's leadership. Snyder \& Strömberg, supra, at 22.

116 BRyan Caplan, THE Myth of THE Rational Voter (2007). However, such a possibility may be overstated. In a study seeking to explain when major federal legislation is revised, Forrest Maltzman and Charles Shipan find that public mood, measuring whether the public favors a 
could, in fact, alter SOX for the worse, as legislators respond to popular opinion by imposing costly and ineffective regulation on business. Contrary to conventional wisdom, then, low salience could perversely produce a higher quality policy outcome from the perspective of social welfare, because in such a scenario, SOX would be modified in response to the judgment of betterinformed individuals.

\section{B. Post-SOX Media Coverage}

\section{Scope of Media Coverage}

Media coverage of SOX's impact was investigated using three sources: national newspapers, regional newspapers, and leading business journalists' columns. The research design uses print rather than electronic media for two reasons. First, the electronic media tends to follow, not lead, print reporting. ${ }^{117}$ Second, the probability of coverage of SOX-related issues would be lower for the network electronic media. That is because newspaper readers can select which articles to read, giving newspapers the advantage of being able to service multiple audiences in contrast to network news programs, whose viewers have no choice of which stories they see while watching a specific network. Thus newspapers can afford greater, and more detailed, coverage of issues that appeal to a narrower audience than the one that network news advertisers target. ${ }^{118}$ Three national newspapers were tracked: the Wall Street Journal and the New York Times, the second and third largest U.S. daily papers respectively, along with the Washington Post. Four regional newspapers were also tracked: the Birmingham News, Boston Globe, Houston Chronicle, and San Francisco Chronicle. ${ }^{119}$ Those newspapers were chosen to provide

more liberal, activist government, is not a significant explanatory factor in a statute's amendment. Forrest Maltzman \& Charles R. Shipan, Change, Continuity, and the Evolution of Law, 52 AM. J. POL. SCI. 252, 262 (2008). Their study is not a conclusive response to Caplan's thesis because it does not control for the direction of the legislative revision, that is, whether it expands or contracts regulation.

117 ARNOLD, supra note 114, at 4, 60. In keeping with this observation, internet coverage of business regulation by the leading blogs of corporate law scholars follows print media coverage, although on occasion, internet bloggers have led the national news media with regard to non-business issues arising during political campaigns.

118 HAMILTON, supra note 21, at 137-38.

119 The position of the Washington Post has fluctuated, with the papers fluctuating around it in the rankings circulating in much larger metropolitan areas (Chicago, Los Angeles, and New York). For circulation and ranking data over the past several years, see Audit Bureau of Circulations, http://www.accessabc.com (last visited June 11, 2009) for 2007 data; Infoplease, Top 100 Newspapers in the United States, http://www.infoplease.com/ipea/A0004420.html (last visited June 11, 2009) for 2006 data; and the John S. and James L. Knight Foundation, Newspaper Diversity Trends at the 200 Largest U.S. Newspapers, http://www.powerreporting.com/knight/top200.html (last visited June 11, 2009) for the 2005 data. I group the Washington Post with the national newspapers for the following reasons. First, it is based in the capital and hence much of its "local" coverage is national in scope. Second, although the percentage of total circulation that is national-that is, outside the D.C. metropolitan area-is small compared to that of the New York Times (10\% compared to $50 \%$ ), it has been much higher than that of the Los Angeles Times, the newspaper with consistently higher circulation than the Washington Post, Lisa M. George \& Joel Waldfogel, The New York Times and the Market for 
geographical, as well as ideological, diversity in coverage. ${ }^{120}$ In addition, three of the papers have substantial circulation, although their circulation is an order of magnitude smaller than that of the national papers. ${ }^{121}$

Six prominent business columnists writing for national newspapers and periodicals were tracked separately from their newspapers: Alan Abelson (Barron's), Holman Jenkins and Alan Murray (Wall Street Journal), Gretchen Morgenson and Floyd Norris (New York Times) and Allan Sloan (Newsweek). ${ }^{122}$ The rationale for tracking journalists apart from their newspapers is a literature suggesting that elite media can set the agenda for other media outlets, in which information and viewpoints diffuse across the media. ${ }^{123}$ Distinguishing across the three media sources should help ascertain how, if at all, elite media influence the regulatory apparatus pertaining to business and financial markets. The editorial page of the Wall Street Journal,

Local Newspapers, 96 AM. ECON. REV. 435, 436 (2006) (less than 1\% of L.A. Times' total circulation is outside of California), as is the popularity of its website, HAMILTON, supra note 21 , at 197-98. Finally, the Washington Post is published where members of Congress and their staff reside for at least some part of the year, and therefore it is likely to exert greater influence nationally than its circulation might otherwise suggest. Indeed, the Washington Post is conventionally included in lists of the "elite" press, along with the other two national newspapers I surveyed. See David L. PALETZ, THE MEDIA IN AMERICAN POLITICS 71-72 (2d ed. 2002).

120 According to a measure of "media slant" that indexes a newspaper's political ideological slant in coverage based on the relative use of phrases identified from congressional debates and calculated for 417 newspapers, in the most comprehensive effort to generate such a measure, the Boston and San Francisco papers are on the left of the political spectrum and the Birmingham and Houston papers are on the right, with respective slant measures of $.424, .403, .462$, and .489 . Matthew Gentzkow \& Jesse M. Shapiro, What Drives Media Slant? Evidence from U.S. Daily Newspapers (Nat'1 Bureau of Econ. Research, Working Paper No. 12707, 2006), available at http://faculty.chicagogsb.edu/matthew. gentzkow/biasmeas052507.pdf. This slant measure places the San Francisco Chronicle as more Republican-leaning than only $6 \%$ of the 417 newspapers from which the measure is derived, and the Houston Chronicle as more Republican-leaning than approximately $64 \%$ of those papers. The slant measures of the national newspapers also reach across the political spectrum and match the regional newspapers' measures and intuition: the New York Times and the Washington Post are on the left and equivalent to the Boston Globe, whereas the Wall Street Journal ranking is on the right and similar to the Houston Chronicle. See infra Table 3. Given the similarity in coverage reported in Table 3, Gentzkow and Shapiro's measure of ideological slant would not appear to have affected the extent of reporting on SOX.

121 Most recent circulation figures and population estimates are provided in Table 3, and have remained fairly constant over the past few years, with the Houston Chronicle being in the top ten U.S. dailies, the Boston Globe and San Francisco Chronicle being closely ranked in the next ten, and the Birmingham News, considerably smaller, but in the top one hundred. The circulation data and ranks over the last three years are from the Audit Bureau of Circulation, supra note 119, Infoplease, supra note 119 , and the Knight Foundation, supra note 119. The Birmingham News was selected, despite its small circulation, because along with providing desirable ideological and geographical diversity, one of the Enron-era accounting scandals concemed a local firm, HealthSouth, which offered the possibility of examining whether the presence of a scandal affected a newspaper's coverage of SOX-related issues.

122 A seventh journalist, Carol Loomis (Fortune), was also tracked, but the search identified no articles by her touching on any relevant topic pertaining to SOX.

123 See Werner J. SEVERIN \& James W. TANKARD, JR., COMmUNiCATION THEORIES: ORIGINS, METHODS, AND USES IN THE MASS MEDIA 232 (5th ed. 2001). One of the studies identifying intermedia influence summarized by Severin and Tankard found that the columns of the New York Times reporter on the 1972 presidential campaign beat were used by other reporters to determine what to emphasize in their coverage of the campaign. 
the leading business newspaper, was also separately tracked and included in the leading journalist category, as it is a national editorial page that is thought not only to possess a distinctive editorial voice but also to wield clout, specifically when it comes to the economy and business.

The individual journalists and Wall Street Journal editorials were tracked from January 2001, well before Enron collapsed and SOX was enacted, in order to ascertain whether there was any prior discussion of the need for the substantive provisions of SOX that were enacted in response to the scandals. ${ }^{124}$ There was none. Although many components of SOX, such as increasing the independence of the board and of the auditor, had been advocated by commentators and interest groups many years before SOX's passage, those issues were not in the public eye prior to Enron's implosion. ${ }^{125}$ The absence of news stories by prominent business journalists discussing such governance proposals pre-enactment reinforces the characterization that the legislation was hastily cobbled together in a crisis atmosphere by well-positioned policy entrepreneurs who had Senator Sarbanes's confidence. ${ }^{126}$ SOX's principal provisions and their financial consequences did not receive even a semblance of public airing or of serious deliberative consideration. ${ }^{127}$

124 The search used to identify the SOX-related newspaper articles in the three media sources is described in the Appendix.

125 Romano, supra note 15 , at 1523 . For example, the national journalists wrote only two articles that referred to directors, or board independence, before SOX's enactment, and both were straight news analysis by Gretchen Morgenson reporting on the NYSE's consideration of a proposal to split the positions of board chairman and CEO (which was not adopted), and its adoption of a rule to require a majority of the board to be independent, on April 5, 2002 and June 6, 2002, respectively. These proposals were the Exchange's response to Enron. In contrast, over a year after SOX was enacted, from 2004 to 2005, Morgenson wrote nine columns on boards, most of which were calls to increase board independence, and almost all of the other columnists wrote at least one column on board independence in the post-SOX period.

126 Romano discusses the individuals at Senate hearings who appear to have influenced the Senate bill. Romano, supra note 16, at 1568-85. Without an insider's account, it is impossible to identify precisely who the most influential individuals were among the lawyers, government officials, and academics with whom Senator Sarbanes and his staff had contact. But it is sufficient to note that those individuals have scant confidence in markets as efficient mechanisms and a decided preference for regulatory solutions, in keeping with the Senator's perspective.

127 Romano, supra note 15, at 1549. Robert Prentice and David Spence take issue with my characterization of SOX's enactment, asserting both that the legislative process I described critically is standard fare and that, were the legislation to have been crafted in a more deliberative fashion, business would have captured the process and produced a statute that would have been contrary to the public interest. Robert A. Prentice \& David B. Spence, Sarbanes-Oxley as Quack Corporate Governance: How Wise Is the Received Wisdom?, 95 GEO. L.J. 1843 (2007). They are mistaken on both counts. First, they are mistaken about the role of business in the legislative process; their analysis is informed by a dated literature. As Mark Smith elaborates in his comprehensive study of business lobbying, when business "wins" in a deliberative process over controversial regulation, it is because the public supports its position and not because of legislators' capture by business. MARK A. SMITH, AMERICAN BUSINESS AND Political Power: Public OPinion, Elections AND DemocraCy (2000). Similarly, Sarah Binder notes that the ability of interest groups to influence legislation - either facilitating or blocking passageis overblown, reporting that the most comprehensive study of interest group lobbying finds no evidence that lobbying by business groups, even when not opposed by other groups, affects the probability of legislation's passage. BINDER, supra note 24, at 31 . Second, Prentice and Spence's assertion, that a more deliberative legislative process would be invisible and thereby enable business to conspire with legislators to produce legislation against the public interest, is a fantasy. The trial bar and labor union 


\section{Coverage of SOX's Impact on Small Firms and Market Competitiveness}

Tables 2 and 3 indicate the scope of the coverage of the two core issues on which the critique of SOX has centered: an adverse impact on capital-market competitiveness and disproportionately high costs for small firms. There are three core findings. First, not surprisingly, press coverage mentioning critiques of SOX steadily increased over the surveyed period, while references to Enron receded. Second, market competitiveness issues tend to receive far more attention than small firms' costs, although many of the untabulated stories (the "Total SOX" line in the tables) report on SOX compliance costs, an overlapping concern. Third, and most intriguing from a political economy perspective with regard to forecasting SOX's future, regional newspapers have directed significantly more attention to small-firm costs than to market competitiveness issues, relative to the coverage of national newspapers and journalists.

\section{a. Temporal Pattern of Reporting on Criticisms of SOX.}

The initial articles critiquing SOX appeared two years after SOX's enactment, not surprisingly at about the time when large firms had to implement the internal controls attestation required by section 404 . The steady increase in coverage of the SOX critiques over the surveyed period is

and public pension funds possess significant political influence, and are as active as business organizations, if not more so, behind the scenes in the legislative process, as recently illustrated by their sophisticated campaign of lobbying legislators, the SEC, and even the Supreme Court, over litigation discussed in note 55, supra. See Kara Scannell, Big-Money Battle Pits Business vs. Trial Bar, WALL ST. J., Oct. 9, 2007, at Al. Consistent with that example, Frank Baumgartner and colleagues, in a comprehensive study of policy change, find that in the vast majority of cases, the resources arrayed on both sides are in equipoise. That is to say, the involvement of "resource rich" organizations such as the Chamber of Commerce mobilizes the matching of resources of opponents. FRANK R. BAUMGARTNER ET al., LobBying AND POLICY Change: Who Wins, Who LOSES, AND Why 203-13, 232 (2009). We simply do not know what the answer to the counterfactual would have been from a more deliberative and reasoned legislative process, nor, of course, do Prentice and Spence offer any evidence for their claim that the position taken by firms on proposed regulation is necessarily at odds with investor welfare and the public good. Third, SOX's frantic enactment is not standard fare: prior major financial-market regulation, such as the federal securities legislation in the 1930s and the FCPA of 1977, was drafted after several years of congressional hearings and agency investigation into financial scandals.

There are other inconvenient facts concerning the legislative process that Prentice and Scott do not get straight in their attempt to rationalize the lack of deliberation regarding SOX's governance provisions. For example, they incorrectly assert that House Democrats did not discuss governance provisions because the Republicans controlled the debate, and hence that my criticism of the absence of deliberation on the governance provisions in SOX is inapposite. But as noted in my earlier article, the Democrats did not discuss the SOX governance provisions on the chamber floor because their bill did not contain those governance provisions, which were add-ons to the Senate bill, and not because Republicans employed House rules to prevent consideration of such proposals. Romano, supra note 15, at 1551. Following the admonition often attributed to Senator Daniel Patrick Moynihan, Prentice and Scott are most certainly entitled to their opinion regarding the merits of SOX's substantive content, but not to their own facts. 
consistent with both firms' continuing to find SOX compliance onerous, and the progression of reports on the burdens imposed on public firms by the statute.

The reporting on SOX critiques does not, however, fit a pattern of agenda setting by elite media. There is no evidence of a pattern of diffusion of coverage from either national journalists or national newspapers to regional newspapers. ${ }^{128}$ In fact, the overwhelming number of articles (over $90 \%$ ) reporting on SOX critiques in regional newspapers had no temporal relation to a national journalist's columns. ${ }^{129}$ Similarly, over half of the regional newspapers' reporting on SOX critiques had no temporal connection to national newspaper coverage, and there was no gap in timing for another third--that is, regional newspapers published articles on the same day as national papers. ${ }^{130}$ In my judgment, regional newspapers' editorial choices on SOX can therefore best be characterized as affected by unfolding events and not as set by the elite media's agenda, as studies of news coverage of social issues have found. ${ }^{131}$ This finding provides an additional rationale for examining regional as well as national newspapers' coverage of SOX to obtain a better gauge of the prospect for legislative action.

\section{b. Substantive Pattern in the Coverage of SOX Critiques.}

The most suggestive pattern in the post-SOX coverage is a notable difference in relative emphasis between the elite press (national journalists and newspapers) and regional newspaper reporting on the two principal critiques of SOX. As indicated in Tables 2 and 3 , national journalists and national newspapers pay more attention to market competitiveness than small-firm costs, while regional newspapers referred about equally to the two lines of criticism and thus comparatively more frequently to costs borne by small firms. ${ }^{132}$ In 2005, when coverage of SOX critiques began, national newspapers

128 A more detailed comparison of the sequence of coverage of the three media sources is provided in the Appendix. For convenience, the slice of the media in the sample consisting of the six leading business journalists and Wall Street Journal editorials will be referred to henceforth as "national journalists."

129 In addition, none of the regional newspapers published or referenced any of the national journalists' SOX-related columns, although they did, on occasion, carry other columns by the journalists, or reference them.

130 As discussed in the Appendix, many of the articles in the regional newspapers were obtained from wire services or other newspapers. Because the wire stories are typically published in a regional newspaper one day after they appear on the wire, it is possible that regional newspapers' selection of wire service articles is made in response to reading a story in a national newspaper. However, in my judgment, that explanation is not plausible. As detailed in the Appendix, which examines coverage by the Associated Press ("AP") wire service, the regional newspapers were not only highly selective in publishing stories from the wire, but also, a large number of the wire service stories preceded, or were unrelated to, the timing of a national newspaper story.

131 The subjects of the news coverage in research identifying intermedia influence were drugs and a presidential campaign. SEVERIN \& TANKARD, supra note 123, at 232.

132 The difference in coverage is statistically significant: a cross-tabulation of the type of critique by type of paper (aggregating counts for regional versus national papers) has a chi-square of 9.2 
published more stories on small-firm costs than on market competitiveness compared to national journalists. But thereafter the newspapers' reporting mirrored the journalists' greater coverage of market competitiveness issues, and the difference in reporting across the elite media sources is insignificant. ${ }^{133}$

A difference in perspective across regional and national newspapers, informed by financial considerations and regarding what are the most important business issues to report to readers, would seem to provide a straightforward explanation for the observed difference in coverage. Small-firm issues have a local dimension, as small firms typically comprise the largest number of businesses in a locality, and their issues would therefore be of greater relative interest to regional rather than national newspaper readers. Such a local connection would be encountered throughout the country, as small firms are ubiquitous. In support of this conjecture, there is no difference in relative coverage of small-firm costs and market competitiveness issues across regional newspapers, indicating that a paper's geographic location did not affect the balance accorded the critiques. ${ }^{134}$ A difference in coverage across regional and national newspapers, but not among regional papers, which reflects differences in what issues resonate with national and regional newspaper readers, is consistent with observed industry responses to competition: regional newspapers increase their emphasis on local stories to maintain a subscriber base when a national newspaper enters their market. ${ }^{135}$

(significant at .002). The cross-tabulation is also significant if the coverage of the regional newspapers is compared to that of the journalists, or to that of the national newspapers and journalists combined, chi squares respectively of 4.4 (significant at .04 ) and 9.9 (significant at .002). As discussed in the Appendix, there is some overlap in the issues involving small-firm costs and market competitiveness, which requires caution when making comparisons. For example, articles discussing the increased cost of an IPO or being a public company due to SOX are classified in the market competitiveness critique category, although most firms that would undertake an IPO are small and the statute's adverse impact on IPOs affects small firms' cost of doing business. But the comparison is even starker across news sources if the market competitiveness stories without any foreign firm or market reference are excluded, because most of the national press stories had a foreign firm or market angle, whereas that was not the situation in the regional papers. The respective chi-squares of the cross-tabulation of critiques where the market competition stories include only those with a foreign firm or market reference, are 11.4 (significant at .001 ) for regional versus national newspapers, 6.7 (significant at .01) for journalists, and 12.6 (significant at .000) for national newspapers and journalists combined. Accordingly, whatever the measure, the relative coverage differed significantly across the regional and national media.

133 The cross-tabulation of article type for national papers versus journalists is not significant, whether or not non-foreign referenced stories are included in the market competitiveness article total (chi-square values of .0001 and .04, respectively). These findings suggest, as the text points out, that any discrepancy in issue coverage across the two groups was extremely short-lived. A possible explanation of the shift in national coverage is that the newspapers' perception of the national SOX story shifted in conjunction with the publication of the committee reports, moving from small-firm costs to capitalmarket competitiveness, the focus of the three latter commissioned reports.

134 A chi-square test of the cross-tabulation of article type against the four regional newspapers is insignificant (chi square of 1.4, using all market competitiveness articles or chi square of 0.4 , excluding articles with no foreign references).

135 George \& Waldfogel, supra note 119, at 436 (finding that regional newspapers' coverage changes when a national newspaper enters their market, indicating differences between regional and national newspaper audiences). 
National journalists would be less focused on matters of local import rather than those having broader national implications, and therefore, they are more likely to view global market competitiveness as an issue demanding greater attention than small firms' operating costs. Of course, straitened financial circumstances of small firms can have significant national implications, as they are an important source of new employment and innovation. But such an effect due to SOX is not easily quantified. It is noteworthy that none of the committees or other organizations expressing concern over the issue has even attempted to estimate such an impact, in contrast to the many reports quantifying losses to stock exchanges and the financial services industry from foreign capital-market competition. It is conventional wisdom in media research that the press is best able to affect the public agenda when issues are concrete rather than abstract. ${ }^{136}$ An additional explanation, then, for national journalists' failure to attend to small-firm costs as an issue of importance to the national economy is that the payoff in terms of influencing and informing the policy debate would have been perceived to be higher from reporting on the issue with a more concrete national economic impact-market competitiveness.

A declining trend in IPOs or foreign listings is also of particular importance to stock exchanges and the financial services industry, whose profitability is in no small part affected by such transactions. That financial sector is heavily concentrated in New York, where the national journalists' publishers and two of the national newspapers are headquartered, providing a compelling, complementary explanation for competitiveness to be a particular focus of their attention. One in nine jobs in New York City is in the financial services industry, and that sector generates over one-third of the city's business tax income. ${ }^{137}$ At $15 \%$ of the gross city product, the industry is second only to real estate in importance. ${ }^{138}$ Editors and reporters for those newspapers would no doubt be attuned to this specific competitiveness issue because it is of substantial interest and importance to their readers. ${ }^{139}$ This contention is buttressed by the contrasting reporting of the non-New York-based national newspaper in the study, the Washington Post. As Table 2 indicates, the Washington Post published far fewer stories on market competitiveness than either the New York Times or the Wall Street Journal, and it had a lower ratio of market competitiveness to small-firm cost stories, paralleling the regional newspapers' coverage. In fact, the Washington Post's coverage cannot be distinguished from that of regional papers, whereas both the Washington Post

136 SEVERIN \& TANKARD, supra note 123 , at 228-29.

137 MCKINSEY \& Co., supra note 65, at 10.

138 Id.

139 For instance, slightly over half of the New York Times's circulation is national, with the New York metropolitan area accounting for the rest. Because the Wall Street Journal is the leading financial newspaper, historically forgoing publishing when the stock exchange is closed, reporting on the stock exchanges' financial condition would be expected to be of particular interest to its readers. 
and the regional newspapers' reporting differs significantly from that of the New York Times and Wall Street Journal. ${ }^{140}$

The differential coverage of issues relating to the SOX critiques by regional newspapers compared to the New York-based national newspapers has important ramifications for predicting how Congress and the SEC will respond to SOX, as well as for understanding recent congressional votes. Earlier mentioned studies of local media coverage of members of Congress and the media impact study of Indian state elections imply that coverage by regional newspapers has electoral consequences. ${ }^{141}$ This suggests that mitigating SOX's burden on small firms - the issue mentioned relatively more often by regional newspapers-would have a higher likelihood of moving onto Congress's agenda than improving market competitiveness, counter to what might be inferred from examining solely the New York-based national newspapers' coverage. In addition, the probability of a political response would be expected to increase as elections draw near, as legislators, seeking to improve their electoral prospects, will be more attentive to issues of concern to their constituents, whose priorities are picked up in regional newspapers. Accordingly, members of Congress up for reelection should be more attuned to small-firm costs than those not up for reelection or those with safe seats. Such hypothesized behavior is, in fact, observed in the data. ${ }^{142}$

Moreover, if market competitiveness issues were voiced in the political arena, we would expect legislators whose constituents are employed in the financial services industry, such as legislators from the New York metropolitan area, to raise those concerns most forcefully, in accordance with the focused coverage of SOX-related issues of the New York-based national newspapers. New York public officials' sponsorship of the McKinsey Study illustrates this point.

140 Cross-tabulations by article type, small firm and market competitiveness (all or foreignonly stories) of the three national newspapers indicate that their relative coverage is indeed different, and the source of the difference among the three papers is the reporting in the Washington Post. Namely, the cross-tabulations of article type are statistically significant at less than .05 when the Washington Post is compared to the New York Times and Wall Street Journal (chi-squares of 6.3 and 9.3 with the comparison between small-firm costs and all market or foreign-only competitiveness stories, respectively), or when the Washington Post is compared to the New York Times and Wall Street Journal stories combined (chi-squares of 5.1 and 7.3 , for the respective comparisons). Other permutations comparing the coverage of the three national newspapers are not significant. Moreover, the crosstabulation of stories in the Washington Post compared to the regional newspapers is insignificant, whereas it is significant when both the New York Times and Wall Street Journal are compared to the regional newspapers for the market and foreign-only competitiveness stories (respective chi-squares of 12.3 and 15.3, each significant at less than .001 ). By contrast, cross-tabulations of the stories across the regional newspapers are insignificant, indicating that their coverage is indistinguishable.

141 See Besley \& Burgess, supra note 112. The Ferraz and Finan study of Brazilian city elections, supra note 111, similarly implicates the importance of local media outlets, although it examined the impact of the presence of local radio stations and not print media. It should be noted that neither the India nor the Brazil study measured the extent of actual reporting on the issue by the local media; their shared assumption is that coverage correlates with their measure of media presence.

142 See discussion infra Part II.C.2. 


\section{Coverage of the Commissioned Reports}

The news coverage of the commissioned reports generally received less coverage than the SOX critiques, although reporting on the critiques and reports is highly correlated. ${ }^{143}$ In addition, the coverage of the four reports varies considerably; in particular, the focus of reporting differs significantly across news sources, often tracking the differences in emphasis accorded the SOX critiques.

\section{a. Coverage of the Advisory Committee}

The Advisory Committee Report received the most attention of the four reports, which would be expected as it was government-sponsored and it was the first report critical of SOX. Although its creation and activity were noted by all of the newspapers, it was ignored by all national journalists save one: Floyd Norris. ${ }^{144}$ This pattern parallels the journalists' overall inattentiveness to SOX's imposition of costs on small firms, which was the Advisory Committee's focus.

All of the regional newspapers reported on the Advisory Committee, consistent with the ubiquity and local character of small-firm issues, although the San Francisco Chronicle referred to it more frequently than the other regional papers. The substantially greater coverage of the Committee by the San Francisco Chronicle, compared to the other regional papers, could plausibly be a function of the legislation's impact on the large number of startup firms in the Bay area-small companies that would be particularly concerned about section 404 costs. ${ }^{145}$

143 When using the term "articles referencing a report," this Article includes both articles referencing entities issuing a report and articles referencing one of the reports directly. The pair-wise correlations for the different types of articles (small-firm costs, market competitiveness, foreign firm competitiveness references, total all SOX critiques, and committee reports) range from .82 to .94 , all significant at less than .05. In addition, as indicated in the Appendix, there is considerable overlap in the report and critique counts. In particular, articles referring to the Capital Markets Committee and McKinsey Study often discussed market competitiveness, and such articles are counted for both types of references. Similarly, articles referring to the Advisory Committee often discussed small-firm costs. The fact that the number of articles referencing market competitiveness is higher than that for committee reports when overlaps are disregarded, in aggregate and for journalists and newspapers separately, supports the contention that the committees received less coverage than the critiques. In addition, more than half of the references to committee reports are overlaps, whereas the proportion is under one-third for market competitiveness references. The proportion of overlaps for small-firm cost references is closer to that of the Advisory Committee, over half for most news sources, and the number of nonoverlapping small-firm cost references is about equal to those for the Advisory Committee-reflecting, in part, the lesser attention paid to small-firm issues by the national press.

144 Greater descriptive detail about the national media's coverage of the commissioned reports is provided in the Appendix, including some of that reporting's personal attacks on individuals associated with the reporting entities or their sponsors. The journalistic style of personal attacks, followed on occasion by the elite press, did not appear in any of the articles in regional papers.

145 Consistent with that explanation, a much higher proportion of the San Francisco Chronicle's articles in the market competitiveness critique category concerned the adverse impact on the cost of going public for domestic firms, and did not reference foreign firms or markets, than did those of the other regional newspapers. Only $42 \%$ of San Francisco Chronicle stories are foreign-only market competitiveness stories, compared to over $60 \%$ for the other regional newspapers. The chi-square of 2.7 
The content of the regional newspapers' articles on the Advisory Committee, however, typically consisted of passing references to its formation and news briefs mentioning its recommendation to exempt small firms from SOX (with the exception of some of the stories taken from wire services). The value of such reporting would at first glance appear trivial, given the total lack of depth to the coverage. But media researchers contend that even cursory reporting can be informative. For example, monitoring theories of the media evaluate content on how well it alerts citizens to issues relevant to their own or the public's welfare, rather than its accuracy or detail, and characterize individuals as scanning, rather than reading closely, their information environments in order to make decisions or take political action. ${ }^{146}$ It is therefore altogether possible, if not probable, that brief or passing references to the Advisory Committee in regional newspapers could have functioned in such a manner.

\section{b. Coverage of the Capital Markets Committee, McKinsey Study, and Chamber of Commerce Commission}

When viewed in conjunction with reporting on the Advisory Committee and the SOX critiques, four patterns appear in the coverage of the three commissioned reports, whose recommendations focused on capital-market competitiveness, compared to that of the Advisory Committee. These patterns involve differences in coverage of the reports across media sources, and in relative coverage of the SOX critiques.

First and most interesting, underscoring the pivotal importance of the preferences of a newspaper's readers in informing a newspaper's content, the Washington Post's coverage of the commissioned reports equaled that of the critiques, in contrast to all of the other newspapers, whose coverage of the critiques by far exceeded that of the reports. ${ }^{147}$ This pattern is intuitively understandable: the business of the national government is local coverage in the District of Columbia, and the reports and their issuing entities all had a government connection. ${ }^{148}$

Second, the national journalists' coverage of the reports replicated their reporting on the SOX critiques, in that they all covered the Capital Markets

for a cross-tabulation of foreign-only to non-foreign-only market competitiveness stories for the San Francisco Chronicle as against the other regional newspapers is, however, only marginally significant at .10 .

146 John Zaller, A New Standard of News Quality: Burglar Alarms for the Monitorial Citizen, 20 POL. COMM. 109 (2003).

147 The cross-tabulation of article type (reports versus critiques) for the Washington Post against all of the other newspapers is statistically significant (chi-square of 6.8, significant at less than $.01)$.

148 Additional anecdotal evidence of the distinctive political-beat focus of the Washington Post is that it was the only newspaper of those surveyed to publish stories about Bush advisor Karl Rove's ownership of Enron stock during the coverage of the Enron accounting scandal. 
Committee, which focused on market competitiveness issues, and not the Advisory Committee report.

Third, the format of the regional newspaper treatment of the reporting commissions differed between the Advisory Committee and the other three. ${ }^{149}$ Whereas Advisory Committee coverage was, in general, highly schematic, providing little information, half of the articles covering the other reports provided information on the rationales along with criticisms of the recommendations. Several institutional factors no doubt contributed to the difference in coverage. The Advisory Committee operated over a substantial time span and in public view. It issued several reports to which the SEC responded, a process lending itself to squib reporting, as its deliberation moved forward. By contrast, the Capital Markets Committee did not operate in public and produced a report only a few months after its formation, with no incremental activity that would befit squib reporting. In addition, those papers' readers may well have been more familiar with the small-firm cost issues addressed by the Advisory Committee than with the market competitiveness issue raised by the Capital Markets Committee Report, and the newspapers may have adjusted their reporting accordingly.

Finally, the national newspapers' editorial posture toward SOX mirrored the divergent views of their journalists regarding the Capital Market Committee's recommendations and the competitiveness critique. ${ }^{150}$ The Wall Street Journal published several editorials that were critical of SOX, whereas the New York Times and the Washington Post editorials, while conceding that some "tweaking" of SOX to recalibrate the most onerous provisions would be valuable, opposed any large-scale changes to the legislation. ${ }^{151}$

The variation across national journalists which tracked the newspapers' editorial pages, along with more frequent one-sided reporting on the commissioned reports by the New York Times compared to the Wall Street

149 In addition, there was more lopsided coverage of the Advisory Committee by the San Francisco Chronicle than the other regional papers. That coverage reflects the fact that a larger number of its articles on small-firm costs also referred to the Advisory Committee, compared to the overlap of articles on market competitiveness and the other reports, as discussed in the Appendix and tabulated in Table Al. Of course, this was an editorial choice: most of the Advisory Committee coverage was in wire service stories, and those services' coverage was not as lopsided as the paper's. For example, four of nine San Francisco Chronicle articles referencing the Advisory Committee were Associated Press stories. During the sample period, the AP coverage of the Advisory Committee was slightly lower than that of the other three committees (22 versus 27 articles, excluding repeated articles), and the San Francisco Chronicle did not run any of the AP articles referencing the other three committees. The Appendix provides a more detailed analysis of regional newspapers' selective use of external sources in their reporting on the SOX critiques.

150 Two journalists (New York Times and Washington Post) expressed skepticism over the rationale for the Committee's work and recommendations, that SOX had caused a decline in U.S. stock markets' competitiveness; one (Wall Street Journal) expressed credence in that view; and a fourth (Wall Street Journal) considered SOX a drag on the domestic economy and the Committee's focus on stock exchange competitiveness a political tactic to garner support from influential New York Democrats.

151 E.g., The Corporate End Run, N.Y. TIMES, Nov. 12, 2006, at A11; Fine-Tuning Finance, WASH. Post, June 9, 2005, at A20; Holding the Line, N.Y. TIMES, Jan. 2, 2007, at A16; Not Just Bad Apples, WASH. POST, May 26, 2006, at A20. 
Journal, suggests that a newspaper's overall political orientation influences the tone and content of reporting on SOX, although ideology has no bearing on the frequency of SOX coverage. ${ }^{152}$ Of course, reporting differences in political ideology do not imply media manipulation of the public. Rather, as the media research literature suggests, media slant is most plausibly interpreted as reflecting the policy preferences of a news outlet's readership.

\section{Saliency of Post-SOX Pushback Reporting.}

What should be made of the steadily increasing post-enactment coverage of SOX critiques and related stories, including the commissioned reports, during the period under study? More concretely, does that trend suggest that the coverage of the critiques has reached a level of salience sufficient to spur legislators and other political actors to respond? Tables 2 and 3 provide one benchmark of salience, the number of news stories in the national and regional newspapers containing a reference to Enron post-SOX. From the perspective of such a benchmark, the coverage of the SOX critiques would appear to be inconsequential. It might therefore seem indisputable to characterize the SOX pushback as not having reached a level of resonance with the press, or visibility to the general public, to affect the prospect of rolling back SOX's strictures. ${ }^{154}$

The fever pitch coverage of all matters related to Enron may not, however, be the most appropriate benchmark for ascertaining whether the critiques being leveled against SOX have reached sufficient salience for legislative action. It would be a mistake to expect the critiques of SOX to reach

152 The difference in balanced reporting across the two papers is discussed in the Appendix. The rate at which the different SOX critiques were covered is similar across newspapers with substantial differences in ideological slant: correlations between the media slant measure and the number of SOX critique stories (in total or by type), are not statistically significant. However, the number of newspapers containing stories in which tone or critical content can be compared is too small to be able to compute a meaningful correlation between qualitative coverage and media slant. Consistent with other researchers' findings, see, e.g., HAMILTON, supra note 21; Gentzkow \& Shapiro, supra note 120, newspaper ownership also does not appear to determine coverage, as there is no systematic relation in coverage by the commonly-owned papers in the sample. The Boston Globe is owned by the New York Times and their media slant measures are quite close, but the pattem of coverage of the papers differed significantly across the SOX critiques: cross-tabulations of critique story type, small-firm costs against market competitiveness (including or excluding non-foreign referenced articles) are significant, with respective chi-squares of 5.5 (significant at .02 ) and 7.2 (significant at .008). By contrast, the Houston Chronicle and San Francisco Chronicle are owned by the same firm (Hearst), and have sharply different media slant, but there is no significant difference in their coverage of critique story types (the chisquares of the cross-tabulations of small-firm cost against market competitiveness articles, all or foreign-references only, are, respectively .004 and .22).

153 HAMILTON, supra note 21; Gentzkow \& Shapiro, supra note 120.

154 The comparison between the counts of articles on Enron and those on SOX critiques and commissioned reports should be made with care: as noted in the Appendix, a large number of the articles in the "Enron" tallies are not even tangentially related to the company's collapse, as the term has entered the vemacular. But even if the count of articles referencing Enron post-SOX is reduced by a large factor, the number of articles reporting on the SOX critiques and commissioned reports would still be a fraction of the Enron count for all of the newspapers. 
the intensive coverage accorded to the Enron accounting scandal. For instance, the media literature suggests that newspaper content reflects readers' taste for information. ${ }^{155}$ The drama and human interest stories surrounding Enron's collapse most certainly were much more fascinating to the public, regardless of ideological commitment, than impersonal reports of the declining number of NYSE-listed foreign companies or the increased cost of internal control audits. Moreover, a study examining the impact of media coverage on U.S. citizens' knowledge of public policy facts (such as, what groups were covered by a presidential health care initiative) found that once an issue received some coverage, additional media attention did not increase that knowledge. ${ }^{156}$ From this perspective, the level of reporting on the SOX critiques may well have met a threshold to inform public opinion on the issues. ${ }^{157}$ Finally, studies of Indian state and Brazilian city elections found a positive correlation between election outcomes and measures of local media presence, rather than actual story content. $^{158}$

The literature identifying a policy impact in the U.S. and other countries from a threshold level of media coverage suggests the possibility that the number of stories critiquing SOX - or referring to the reports critiquing SOXwas sufficient to raise the saliency of the issue to the public, and contributed to the SEC's eventual strategic regulatory retreat. It would not appear to be fortuitous that as the pace of news coverage on the SOX critiques accelerated, almost tripling from that of the previous year, the agency proposed revising its interpretive guidance of section 404 at the end of 2006, even though it did not exempt small firms as the Advisory Committee recommended. ${ }^{159}$

155 For an analysis relating the increase in "soft" news, such as human interest stories, on television news programs to the preferences of the audience most valuable to advertisers, young women, see HAMILTON, supra note 21.

156 Jason Barabas \& Jennifer Jerit, Estimating the Causal Effects of Media Coverage on Policy-Specific Knowledge, 53 AM. J. POL. SCl. 73, 79-80 (2009) (finding after some coverage-around nine stories-additional coverage of ten or more stories did not significantly increase the knowledge of policy facts among surveyed members of the public, where the mean coverage was approximately two stories, with a standard deviation of one, and "high" coverage - which did not impact knowledge-was deemed to be two standard deviations above the mean).

157 A study of EPA pesticide decisions found that the impact of newspaper coverage on regulatory action was nonlinear, such that decisions were affected only when coverage reached a certain threshold. Yates \& Stroup, supra note 111, at 310. It is not possible to infer what such a threshold would be for SOX critiques from the Yates and Stroup study. That study uses article word counts to measure coverage but does not specifically identify the threshold number of words at which they found coverage "high" enough to impact regulators' decisions. But its finding parallels the finding in the Barabas and Jerit study, supra note 156, that found a nonlinear effect, using article counts, on the public's learning about policy proposals.

158 Besley \& Burgess, supra note 112; Ferraz \& Finan, supra note 111. The Indian state elections study used newspaper circulation figures. The correlation between newspaper circulation and the number of articles on small-firm cost, as well as all SOX critiques, is positive and significant at .01 . These correlations support drawing inferences to this Article's data from that study's findings, which relate only to circulation figures and not to news content. As noted in note 141, supra, the Brazilian city study tracked the existence of a local radio station.

159 See Management's Report on Internal Control over Financial Reporting, 71 Fed. Reg. 77,635 (Dec. 27, 2006). Although that action did not address the market competitiveness issue concerning SOX, at the same time as proposing the revised implementation standard, the SEC proposed 
A factor further supporting the contention that SOX was becoming increasingly salient to the public is the location of the stories in the papers. ${ }^{16}$ Table 4 indicates the number and proportion of stories on SOX that appeared on each newspaper's front page or the first page of the business section. The number appears to be substantial, ranging from $21 \%$ to $43 \%$. While most of these stories appeared on the first business page, fifteen (or 9\%) of the SOX articles in the Wall Street Journal, the newspaper with the greatest coverage, were, in fact, front page stories. Moreover, there is no significant difference across the national and regional newspapers in the positional prominence accorded SOX-related stories. ${ }^{161}$ These data bolster the contention that the coverage from 2005 to 2007 was bringing SOX into focus as a salient issue.

Another plausible measure of the salience of the SOX critiques involves post-SOX editorials and commentary on the statute. Paralleling the coverage of all other post-SOX issues, Table 3 shows an increase in articles opposing revising SOX, which indicates that only three years after SOX, journalists and

easing foreign firms' ability to delist, and thereby avoid SOX. See Termination of a Foreign Private Issuer's Registration of a Class of Securities under Section 12(g) and Duty to File Reports under Section 13(a) or 15(d) of the Securities Exchange Act of 1934, 72 Fed. Reg. 1384 (Jan. 11, 2007). Both rules became effective in the spring of 2007. At a recent conference, the SEC's Chief Accountant reported that approximately two-thirds of European companies had deregistered, comparing the current number of registered issuers to that five years ago. SEC Official Says Fewer Companies Coming to U.S. Markets in Registered Forum, 40 Sec. Reg. \& L. Rep. (BNA) 777, 778 (May 12, 2008). Moreover, as discussed in Part III, the SEC thereafter took other action directed at improving market competitiveness, eliminating for many foreign firms the requirement that their accounting statements be reconciled to U.S. accounting principles. Steven Marcy, SEC Ends GAAP Reconciliation for Reports Meeting IASBIssued IFRS, 5 Corp. Accountability Rep. (BNA) 1134 (Nov. 16, 2007). Craig Doidge, Andrew Karolyi, and Rene Stulz examined the stock price reaction of fifty-nine firms that deregistered in the month following the 2007 rule relaxation; it was insignificant. Craig Doidge, Andrew Karolyi \& Rene Stulz, Why Do Foreign Firms Leave U.S. Equity Markets? An Analysis of Deregistrations Under SEC Exchange Rule I2h-6 (The Ohio State Univ. Fisher Coll. of Bus. Working Paper 2008-03-013, 2008). They view that data as proof that SOX did not adversely impact market competitiveness, on the contention that for there to have been an adverse impact, the abnormal return on deregistration must be significantly positive. But if deregistering provides new information about a firm's financial state, for example, that the costs of SOX will be greater than expected future cash flows, then that would lower investors' expectations regarding future profitability, offsetting any positive effect from avoiding SOX. Of course, the data do not actually fit with their positive assessment of SOX, nor their contention that competitiveness is not an issue. If the cost of SOX was less than its benefit or other benefits from a U.S. listing, then they should have found a significantly negative price effect upon deregistration.

160 A number of media studies use as a measure of issue salience a story's location in the newspaper. E.g., Barabas \& Jerit, supra note 156, at 77 (defining prominence in media coverage as appearance on front page); Yates \& Stroup, supra note 111, at 305 (using two coverage variables, word count and location in non-front section). As noted in the Appendix, this article emphasizes frequency counts, rather than location, as a measure of issue salience, as it is the more common approach in the media literature on agenda-setting.

161 A test for a difference in proportions across regional and national newspapers of coverage on the first business page, or both the front and first business pages, was insignificant, with a $\mathrm{z}$-statistic of 1.8 (significant at .07) and 0.66 (significant at .51), respectively, as was the tabulation across regional and national newspapers of first business page or both front and first business page articles versus those located elsewhere, with respective chi-squares of 3.4 (significant at .07) and 0.44 (significant at .51 ). The marginal significance of the first business page comparisons is a function of the Wall Strett Journal's distinctive placement of stories equally on the front and first business pages, compared to all the other papers. 
editorial writers supportive of the statute felt the critiques had made sufficient inroads to require an editorial response. Of the newspapers examined, only the Wall Street Journal editorialized unequivocally for revamping SOX. Not only did many national journalists voice opposition to such a course of action, but also several newspapers advocated against any broad rollback of the statute, at the same time as endorsing the need for some "tweaking." 162

Although the media's near consensus for retention of the status quo, with possibly minor cosmetic tweaking, would appear to suggest that congressional efforts to revamp SOX might be out of step with public opinion, the impact of the media on public opinion is subtle and can be difficult to gauge. Public opinion does not mechanically conform to the view of newspapers informing it on an issue. A newspaper, for instance, can provide a balanced account of arguments for and against a particular policy, or a very one-sided account. Yet readers can come away convinced that one side is correct, or that the side whose perspective was ignored is correct, either due to the implausibility of arguments or the perceived credibility of the arguments' proponents. ${ }^{163}$ Accordingly, even while editorializing in the legislation's defense, coverage of the SOX critiques could ironically boomerang and have the effect of shifting public opinion against the legislation.

It is also probable that the declining references to Enron observed in Table 3 indicate that the scandals that produced SOX were fading from public perception and with it a political environment that did not permit a careful evaluation of its regulatory costs and benefits. Such a change in circumstance would provide further reason for legislators to discount more readily the prevailing media view on SOX. Indeed, concern over such a possibility would appear to have prompted several articles in which journalists sought to inject an Enron-like boost for retaining SOX by attempting to tie it to the scandal of the day involving stock-option backdating. ${ }^{164}$

\section{Interaction Between Interest Groups and Media Coverage for Influencing Public Policy}

Interest group activity undoubtedly also influences the policy agenda, quite apart from media attention to an issue. There is a well-established literature on how concentrated costs and dispersed benefits can result in small numbers of organized individuals disproportionately influencing policy. ${ }^{165}$ This

162 Editorials opining that some tweaking of SOX was necessary along with opposing any broad scaling back of the statute are not counted in the table row as "advocacy against revising SOX." There is no row in Panel B of Table 2 for criticism of SOX because Wall Street Journal editorials are tabulated in Panel A of the table. None of the other newspapers expressed similarly unqualified opinions regarding the need to revamp the statute.

163 Yates \& Stroup, supra note 111.

164 Editorial, Holding the Line, N.Y. TIMES, Jan. 2, 2007, at A16; Loren Steffy, SarbanesOxley Stifling? Say It with a Straight Face, Hous. CHRON., Dec. 22, 2006, Business, at 1; Ben Stein, So Many Millions, So Little Body Armor, N.Y. TIMES, Jan. 7, 2007, §3, at 3.

165 MANCUR Olson, THE Logic OF COLLECTIVE ACTION (1965). 
literature would suggest that the SEC's revised guidance for section 404 could be a response to the lobbying of adversely affected firms, quite unrelated to news coverage. However, it is quite possible, if not probable, that media coverage worked in tandem with lobbying by affected parties by increasing public awareness of problems with SOX, to spur legislators to press the agency to react, even if its response may well have been more symbolic than real. Indeed, the two influence channels-media reporting and interest group lobbying - are not distinct in practice. The political science literature indicates that interest groups often use the media to increase the salience of an issue to persuade legislators of the issue's importance to a broad segment of the public beyond the group's members and thereby move the issue up on the policy agenda. ${ }^{166}$

Media reporting can also facilitate organizational efforts to lobby for legislative change by causing individuals to mobilize around collective interests and by highlighting common problems and potential solutions. ${ }^{167}$ That channel could be particularly important in the SOX context for small business owners to obtain information and to organize politically more effectively, to the extent that they are not connected with a local chamber of commerce that would be a source of such information.

Moreover, the scenarios describing the linkages between media reporting, interest group activity, and the legislative agenda, are in accord with a wellrecognized mechanism spurring legislators' action. Congress has been characterized by use of the metaphor of preferring to engage in regulatory oversight by a fire alarm, rather than a police patrol approach, in which members respond to information from constituents' complaints about agency actions (the constituents "pull" a fire alarm), rather than actively investigate an agency (legislators "sniffing" for a fire) on their own. ${ }^{168}$ Similarly, groups adversely affected by SOX-small firms and stock exchanges--with the assistance of commissioned studies that would attract news reports, no doubt used the media to raise public awareness of the statute's costs in an effort to influence the policy agenda.

\section{Congressional Responses}

Paralleling the newspaper coverage, legislators paid scant attention to SOX until 2005. But from 2005 to 2007, as summarized in Table 5, bills were steadily introduced to reduce compliance costs, particularly for small firms. There was also an uptick in hearings on SOX, as indicated in Table 6. In addition to bill introductions and hearings, there have been three floor votes. The gradual movement through the legislative process of SOX-related

166 KOLLMAN, supra note 109

167 HAMILTON, supra note 21, at 243.

168 Mathew D. McCubbins \& Thomas Schwartz, Congressional Oversight Overlooked: Police Patrols Versus Fire Alarms, 2 AM. J. PoL. SCI. 165 (1984). 
initiatives conveys legislators' heightened sense of unease with regard to SOX, evincing a distinct shift in sentiment and breakdown of support in the five years following its unanimous enactment. ${ }^{169}$

\section{Congressional Activity on SOX}

The regional newspapers' greater relative attention to small-firm issues is replicated in legislators' reactions to SOX's impact, as the theoretical and empirical literature would suggest. Legislators are far more focused on the concerns of small business regarding SOX than on capital-market issues. As indicated in Table 5, the trend of increasing efforts at legislative recrafting began prior to the imminent need for legislative action in 2007 when the SEC's deferral of section 404's applicability to small firms was about to expire: for instance, four of the bills introduced in the 109th Congress (2005-2006) would have exempted small firms or banks. Not surprisingly, the pace increased as the expiration date approached, as six such bills were introduced in the first session of the 110th Congress (2007). Although the vast majority of bill sponsors and co-sponsors were Republicans, who are in the minority, their numbers are substantial. ${ }^{170}$

In addition, Table 6 highlights the quickened pace of congressional hearings on SOX, from one self-congratulatory hearing a year after its adoption held by one of its namesakes, Representative Michael Oxley, to a number of hearings over the succeeding two years in which legislators increasingly voiced concern regarding SOX's cost. These hearings coincided with the increased media attention given to the SOX critiques and are consistent with political scientists' findings that the priorities and attention of the public and Congress are strongly correlated. ${ }^{171}$ Finally, members of Congress have engaged in a variety of other activities short of legislation to express their dissatisfaction with the SEC's lack of responsiveness to small businesses' complaints regarding SOX. For example, both chambers' committees with jurisdiction over small business wrote to the SEC to request a further delay in the

169 The impact on this trend of the subprime mortgage crisis and subsequent credit crunch is discussed in Part III.

170 Adjusting for overlapping sponsorship and cosponsorship, ninety-three legislators signed on to the eight bills introduced in 2007 . This is a noteworthy development because, as earlier noted, cosponsorship is viewed as a signal of voting support. See, e.g., Wilson \& Young, supra note 84. As discussed in the following Section, that was indeed the case, as the vote on SOX in the chamber with higher cosponsorship rates across more numerous bills achieved a majority, although the form of the proposal was also more modest-postponing SOX's implementation for small firms rather than permanent exemption.

171 In a comprehensive political agenda study spanning fifty years of data, Bryan Jones and Frank Baumgartner find that the proportion of congressional hearings on an issue is highly positively correlated with the issue the public identifies as the "most important problem facing the nation." JONES \& BAUMGARTNER, supra note 28 , at 255-60. 
implementation of section 404 for small firms beyond 2007 and to provide them with compliance cost estimates. ${ }^{172}$

In addition to the constituent connection of small firms being located in all districts, evident in regional newspapers' post-SOX coverage, a plausible contributing factor to legislators' focus on SOX's impact on small firms is that public opinion in the United States has historically been decidedly more solicitous of "small" rather than "big" business. For instance, support levels differ significantly across opinion polls when questions use the phrase "big business" instead of "business" or "small business." regulation whose costs unduly burden small firms would therefore better resonate with the public than a broad-based statutory revamping addressed to the concerns of all firms or stock exchanges.

An increase in the number of bill introductions could be thought of as a proxy for the likelihood of legislative action and thus as a measure of political salience. For example, the Commodity Futures Trading Commission Act, ${ }^{174}$ which reorganized futures trading and opened the way for the development of financial derivative products, was enacted after five years of a steady increase in bill introductions. ${ }^{175}$ Common sense would also suggest that an increasing number of bills could spur a preemptive response by other political actors, such as the SEC in this case, in the direction desired by legislators, to ward off a risk of enactment of legislation potentially even less desirable from the agency's perspective.

A similar dynamic is at work in the increase in the number of hearings, which require greater support among influential legislators for action than a bill introduction: at least the committee or subcommittee chair must support a proposal for a hearing, compared to any one member's ability to introduce a bill. The literature finds a positive correlation between the holding of hearings, and in particular an increasing number of hearings, on a subject and statutory enactments, leading political scientists to conclude that hearings are not simply

172 Letter from Nydia M. Velazquez, Chairwoman, and Steve Chabot, Ranking Member, House Committee on Small Business, to Christopher Cox, Chairman, SEC, June 11, 2007, http://www.house.gov/smbiz/democrats/letters/sox-letter-2.pdf; Letter from John Kerry, Chairman, and Olympia Snowe, Ranking Member, Senate Committee on Small Business and Entrepreneurship, to Christopher Cox, Chairman, SEC (June 6, 2007), http://sbc.senate,gov/oversight/lettersout/070606-SECSarbanes-OxleySection404Ltr.pdf; Letter from Nydia M. Velazquez, Chairwoman, and Steve Chabot, Ranking Member, House Committee on Small Business, to Christopher Cox, Chairman, SEC, and Mark W. Olsen, Chairman, PCAOB, Mar. 12, 2007, http://www.house.gov/smbiz/democrats/letters/March9SOX-404-Ltr-FINAL.pdf.

173 Seymour Martin Lipset \& William SCHNEIDER, THE CONFIDENCE GaP: BusinesS, LABOR, AND GOVERNMENT IN THE PUBLIC MIND 86 (rev. ed. 1987).

174 Pub. L. No. 93-463, 88 Stat. 1389 (1974) (codified in scattered sections of 7 U.S.C.).

175 Romano, supra note 2. An alternative view of bill introductions is that they are instances of symbolic politics, position-taking activity that pleases constituents by expressing judgmental support, without having any real consequences; such activity is considered as important for reelection as producing results, given the diffusion of responsibility across the govemment for making policy. See, e.g., DAVID R. MAYHEW, CONGRESS: THE ELECTORAL CONNECTION 61-71, 132-34 (1974). 
exercises in "symbolic politics." 176 That is an observation, again, no doubt, that other political actors would factor into their decision-making. The SEC's decision to revise the guidelines for implementing section 404 would seem to reflect such a calculation. Chairman Cox's reversal of his position concerning the timing of the section's implementation for small firms would likewise appear to be a further example of agency action to head off legislative action.

\section{Votes on Revising SOX}

\section{a. Senate}

In April 2007, the Senate considered a bill entitled the "America COMPETES Act,"177 which had broad bipartisan support: it authorized several billion dollars for research in science and technology and for math and science teachers. Although the majority did not have SOX in its sights when advancing the legislation, the bill was characterized as being directed at "maintaining competitiveness." That led Senator Jim DeMint, the sponsor of a bill that sought to reduce the cost of SOX, to offer up his bill's key component-a provision exempting small firms from section 404 unless they chose to be covered-as an amendment consonant with the America COMPETES Act's stated objective. ${ }^{178}$

Senator DeMint's amendment involved the SEC, a matter within the jurisdiction of the Senate Committee on Banking, Housing, and Urban Affairs ("Banking Committee"), while the bill under consideration had originated in a different committee. That key fact undoubtedly explains the Senator's adoption of an amendment strategy. The Senate's liberal amendment process makes it one of a few available techniques for circumventing a committee. ${ }^{179}$ Senator DeMint's bill had made no progress in the Banking Committee since its introduction in March. When the amendment was introduced, Banking Committee members objected, and the amendment's consideration was postponed to provide the committee an opportunity to review the amendment and discuss it on the floor, as it was the committee with subject matter jurisdiction. When time came to resume discussion on the DeMint amendment,

176 JONES \& BAUMGARTNER, supra note 28, at 262.

177 S. 761, 110th Cong. (2007) (enacted as America COMPETES Act, Pub. L. No. 110-69, 121 Stat. 572 (to be codified in scattered sections of 15 U.S.C.)).

178 The amendment was cosponsored by three Republican senators, two of whom had cosponsored the original bill. The bill, S. 869 , exempted small firms from section 404 , while permitting them to opt in to its requirements, along with instructing the SEC on the development of a materiality standard. Upon its introduction in March, the bill had been referred to the Senate Banking Housing and Urban Affairs Committee, 153 CONG. REC. S3124 (daily ed. Mar. 14, 2007), which had taken no action on the bill. The Senate does not require amendments to be germane to a bill under consideration, but in introducing his amendment, Senator DeMint noted that it was related to the bill, being directed at improving U.S. competitiveness. 153 CONG. REC. S4894 (daily ed. Apr. 24, 2007).

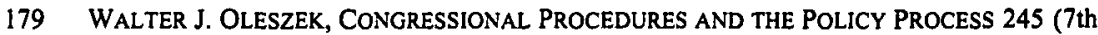
ed. 2007). The approach could be viewed as a variant of the venue-shopping strategy that worked in the House, as discussed infra note 220 and accompanying text. 
Senators Dodd and Shelby, the Chairman and Ranking Member of the Banking Committee, respectively, offered a competing amendment that took precedence procedurally.

The Dodd-Shelby amendment was a resolution consisting of a set of findings regarding SOX, and a "Sense of the Senate" directed to the SEC. The findings included an expression of the importance of small business and U.S. capital markets, along with the assertion that section 404 had "enhanced corporate governance" and "increased investor confidence." 180 The resolution further found that both the SEC and PCAOB had determined that the implementation of section 404 had imposed "unnecessary and unintended" cost burdens on small firms and noted that the agencies were nearing completion of the implementation standard's revision. The final finding referred to the SEC Chairman's statement that there was no need to change the law. The resolution then concluded with a Sense of the Senate that the SEC and PCAOB "should complete promulgation of final rules implementing section 404."181

The strategy informing the Dodd-Shelby amendment is transparent: by offering legislators, as Senator Dodd put it, an "opportunity to express [their] concerns" and to "send a message" that "we care about this," it would sap support from the DeMint amendment. ${ }^{182}$ That is because a legislator could oppose the DeMint amendment but still express support for small business by voting for the Dodd-Shelby amendment. Moreover, doing so was consistent with the perspective of the SEC Chairman, who, as Senator Dodd pointedly noted, was "President Bush's appointee," presumably in an appeal for bipartisan support. ${ }^{183}$ Senator Shelby elaborated on the reason why he supported the amendment: the purpose was to provide the SEC a "limited opportunity to deliver" more cost-effective regulation for small firms, and that the Banking Committee would "closely" oversee that the SEC did so. ${ }^{184}$

The Dodd-Shelby amendment was unanimously adopted. Senator DeMint responded to Senators Dodd and Shelby's move by stating that he would support their amendment while noting that he disagreed with some of the amendment's findings. He then urged his colleagues to vote for his amendment as well, emphasizing that the Sense of the Senate provision maintained the status quo with no guarantee that the agency would ameliorate the regulatory cost for small firms, especially since for five years it had done nothing, in his view, along those lines. ${ }^{85}$

With the unanimous vote recorded on the Dodd-Shelby amendment, the discussion turned to the DeMint amendment. Senators Dodd and Shelby spoke briefly against the amendment, with Senator Dodd contending that the agency,

182 Id. at S4895 (remarks of Sen. Dodd).

183 Id.

184 Id. at S4896 (remarks of Sen. Shelby).

Id. (remarks of Sen. DeMint). 
and not Congress, was the relevant body to resolve the issue, and Senator Shelby disapproving of the "timing" as being premature. ${ }^{186}$ Rather than permit a vote on the DeMint amendment, however, Senator Dodd moved to table it. The motion to table carried by a vote of 62 to 35 (three Senators not voting as they were not present). All but one Democrat voted for the motion to table, along with fourteen Republicans. ${ }^{187}$ This second prong of Senator Dodd's successful strategy to defeat the DeMint amendment-conversion of a substantive vote into a procedural one-is a well-recognized Senate maneuver to avoid a controversial vote. As an experienced legislative strategist, Senator Robert Byrd, has cogently put it:

A motion to table is a procedural motion. It obfuscates the issue, and it makes possible an explanation by a Senator to his constituents, if he wishes to do so, that his vote was not on the merits of the issue. He can claim that he might have voted this way or that way, if the Senate had voted up or down on the issue itself. But on a procedural motion, he can state he voted to table the amendment, and he can assign any number of reasons therefore, one of which would be that he did so in order that the Senate would get on with its work or about its business. ${ }^{188}$

Senator Byrd's explanation resonates with another electoral calculation that may also have informed Senator Dodd's decision-making. An influential group closely associated with the Democratic Party, the AFL-CIO, had sent a letter to Senators Dodd and Shelby urging them to oppose the DeMint amendment for being "anti-investor," and citing SEC Chairman Cox's opposition to legislation to revise SOX. ${ }^{189}$ Although the DeMint amendment was not a high priority of

186 Id. at $\mathrm{S} 4897$ (remarks of Sen. Shelby).

187153 CONG. REC. S4899 (daily ed. Apr. 24, 2007) (Roll No. 139). It is noteworthy that the Democrat who opposed tabling the DeMint amendment was Louisiana Senator Mary Landrieu, who was up for reelection in 2008 and was considered the only vulnerable Democratic incumbent. She had won her seat in 2002 by a narrow margin of 3\% in a runoff election, required by Louisiana law because no candidate had received a majority in the first election. She retained her seat in 2008 with $52 \%$ of the vote, avoiding a runoff.

188 OLESZEK, supra note 179, at 234 (citing 121 CONG. REC. 29,814 (1975)).

189 Letter from William Samuel, Director, AFL-CIO Dept. of Legislation, to Sens. Chris Dodd \& Richard Shelby (Apr. 24, 2007) available at http://www.aflcio.org/issues/legislativealert /alerts/upload/DeMint20070424.pdf. This is not as odd an object of union lobbying as it might seem to some at first glance: over the past decade, unions have become the predominant activist institutional investors, replacing public pension funds as the most frequent sponsors of shareholder proposals on corporate governance, although they would appear to have mixed motives as investor advocates. Empirical research suggests that they employ this strategy to further workplace goals and not solely to maximize share prices, notwithstanding assertions to the contrary. See, e.g., Stewart J. Schwab \& Randall S. Thomas, Realigning Corporate Governance: Shareholder Activism by Labor Unions, 96 MICH. L. REV. 1018, 1033 (1998) (examples of union activism targeting firms involved in organizing, collective bargaining, or other labor disputes); Ashwini K. Agrawal, Corporate Govemance Objectives of Labor Union Shareholders (N.Y. Univ. Stern Working Paper Series No. Fin-08-006, 2008) available at http://papers.ssm.com/sol3/papers.cfm?abstract_id=1285084 (union voting support for election of directors varies with organizing activity and representation). Besides firm level activism, unions have frequently coordinated with Democratic legislators and SEC commissioners to promote their activist 
organized labor, as it was not included on the AFL-CIO's list of key votes, ${ }^{190}$ it provided additional impetus to Senator Dodd's effort to mitigate legislators' having to go on the record against the DeMint amendment. By voting for the Dodd-Shelby amendment, which acknowledged small firms' plight by exhorting the SEC to act promptly, Senator Dodd and other members could support the strictures of the statute, as advocated by organized labor constituents, while simultaneously having a shield from a possible political backlash by small business constituents.

It is improbable that Senator Shelby's joint sponsorship of the Committee Chairman's amendment would have been prompted by the AFL-CIO's position. ${ }^{191}$ Rather, for him and other like-minded Banking Committee members, the Dodd-Shelby motion would leave greater control over the fate of SOX in their hands, positioned as the Senate's watchdogs of the SEC. In addition, the motion would produce the outcome preferred by the SEC Chairman, a member of Senator Shelby's political party in whom Senator Shelby and other committee members would be apt to have confidence given the committee's oversight relation with the agency. ${ }^{192}$ Of course, Chairman Cox's view that legislation was unwarranted because the SEC could address and was addressing the issue administratively, would also be a helpful talking point for cooling out any potential backlash from small firms for Republicans as well as Democrats. But what is most striking is that over two-thirds of the Republicans did not follow Senator Shelby's lead and instead opposed the motion to table, expressing support for a vote on the DeMint amendment.

This vote was the initial indication of substantial legislative support, albeit along party lines and not a chamber majority, for amending SOX to relieve

investor agenda by means of regulation. Examples include Representative Frank's introduction of a bill to require shareholder votes on executive pay, and SEC Commissioners Roel Campos's and Harvey Goldschmidt's push for shareholder nominations under SEC proxy rules.

190 The union's list of key votes for the session is contained in the AFL-CIO 2007 Senate Scorecard. AFL-CIO Legislative Dep't, 110th Congress-First Session, AFL-ClO 2007 Scorecard, http://www.aflcio.org/issues/legislativealert/votes/upload/senate_final_07.pdf (last visited June 9, 2009).

191 On the AFL-CIO's ranking of Senators' voting support of the union's positions, Senator Shelby's 2007 score was $21 \%$ (lifetime score of $37 \%$ ), compared to Senator Dodd's score of $100 \%$ (91\% lifetime). See AFL-CIO 2007 Senate Scorecard, supra note 190.

192 Although a majority of the Republican Banking committee members voted against tabling Senator DeMint's amendment, the four who voted to table it made up a sizeable proportion-29\%-of the Republicans who did so. It must be noted that press accounts attributed Senator Shelby's support for "investor rights" and the enactment of SOX to his having lost money on stock investments in two other accounting frauds that came to light at the time of the fraud at Enron: WorldCom and Global Crossing. Lisa Lerer, Shelby Is Banking Panel's Traffic Cop, POLITICO, Apr. 10, 2008, http://dyn.politico.com /pringstory.cfm?uuid=35DIF564-3048-5C12-00372BE644DC8B8F. It is not possible to provide an assessment of this contention. Interviewed after the Republicans lost control of the Senate in the 2006 election, Senator Shelby stated that he thought SOX needed "tweaking" but should not be "fully repealed," and that if-as he thought was the case-SOX was driving business to London, then "that should first be a concern of the SEC and then [Congress], working with the SEC." Mary Orndorff, Shelby Raises Concern with Law, Says Legislation Scares Away Business, BIRMINGHAM NEWS, Nov. 15,2006 , at $1 D$. 
small firms' costs. ${ }^{193}$ Although the wording of the unanimously adopted competing resolution expressing an endorsement of SOX indicates that the statute still possesses considerable support in Congress, the votes on the motion to table suggest that were Republicans to regain control of the chamber, a provision cutting back on SOX's reach might well carry. This is a remarkable development given the unanimous endorsement of SOX in the Senate just five years earlier.

The vote on the motion to table, albeit procedural, provides a means for inferring which legislators would be most likely to support legislation revising SOX. Table 7 provides univariate comparisons of supporters and opponents of the motion along a variety of state and personal characteristics. It includes measures that serve as proxies for small-firm constituents, including the number of business establishments and of local chambers of commerce in a senator's state, along with campaign contributions from the Chamber of Commerce. As a benchmark for constituents who might be affected by capitalmarket competitiveness, the analysis measures the proportion of total campaign contributions raised from individuals and organizations in the securities and investment industries. ${ }^{194}$ In addition, the Table provides individual factors that could affect a legislator's responsiveness to constituents (whether the senator was up for reelection in 2008, the margin of victory in the senator's last election, and longevity in office), along with legislative positions or activity that could impact a legislator's perspective on the amendment (party leadership position, membership on either the Banking or Small Business Committees, and sponsorship or cosponsorship of a deregulatory bill on SOX). ${ }^{195}$

193 A vote against a motion to table is, of course, not identical to a vote in favor of the substance of the amendment to be tabled. But it is reasonable to infer that the thirty-five senators opposing the motion to table in this case would also have voted for the amendment.

194 The number of business establishments is from the 2003 census; the number of local chambers of commerce was obtained from chambers identified in the WorldWide Chamber of Commerce Guide, http://www.chamberfind.com/index.asp (last visited June 11, 2009). All of the campaign contributions are for senators' most recent six-year election cycle, as compiled by the Center for Responsive Politics from Federal Election Commission reports. OpenSecrets.org, Money in Politics-See Who's Giving and Who's Getting, http://www.opensecrets.org (last visited June 11, 2009). Because the Center compiles contributions by sector only for a legislator's top twenty industry contributors, two Republican senators have zero values for securities and investment industry contributions (one voted for and the other voted against the motion). Campaign contributions were used instead of a geographic indicator variable as a proxy for a senator's representation of constituents affected by market competitiveness concerns because all of the senators from the New York metropolitan area-the region most affected by the issue-are Democrats and therefore not included in the analysis.

195 The electoral margin is the difference in votes between the elected legislator and the largest vote-getting opponent, and was obtained or calculated from states' official election results, or in a small number of instances where official state data were not available, from reports in the news media or Wikipedia. For candidates with no opposition but where the state included blank ballots in its official results, the blanks were included in the calculation. The margin was also computed where two opponents' total votes were approximately equal, by subtracting that sum rather than only the leading candidate, and where a candidate was unopposed, by ignoring blanks, which increases the margin for House Democrats voting against the amendment to $52 \%$. The means comparison tests are unchanged across the alternative calculations. Years in office, age, reelection in 2008, leadership position. and 
Paralleling the regional newspapers' focus on small-firm costs, Table 7, which displays univariate differences between Republican senators voting for and against the motion to table, indicates that an electoral connection contributes to legislators' attentiveness to the small-firm issue, as evinced by supporting Senator DeMint's amendment. Republicans who opposed tabling the amendment are from states with a significantly larger number of business establishments and local chambers of commerce than are in the states of Republicans who voted to table it. In addition, the opponents of the motion to table appear to have less electoral slack: they had been in office for less time and elected by a significantly smaller margin than Republicans who voted to table the amendment. Finally, senators opposed to tabling the DeMint amendment had received larger contributions from the Chamber of Commerce than those favoring it. It is difficult, however, to attribute much independent import to the difference in contributions as measuring a Senator's probability of supporting chamber issues, because higher contribution levels may be a function of the perceived closeness of the senator's election contest. Finally, the vote does not appear to have been ideologically driven among Republican senators: although supporters of Senator DeMint's amendment are more conservative than opponents by a conventional ideology measure generated from roll call votes (mean DW-NOMINATE score of .5 for supporters compared to .42 for opponents), the difference is not statistically significant.

Table 8 reports the results of a multivariate regression analysis that controls for the characteristics of legislators compared one-by-one in Table 7. ${ }^{196}$ Small-firm constituent considerations do appear to matter in differentiating Republicans' voting. The number of business establishments is significantly and positively related to voting against tabling the amendment, and Chamber contributions are marginally significantly positive. Electoral vulnerability did not, however, affect the votes. The only personal characteristic that is significantly associated with support for the DeMint amendment is cosponsorship of a deregulatory bill on SOX. ${ }^{197}$ The significance

committee membership were obtained from each senator's individual page on the U.S. Senate website. Senators' ideology is measured by the DW-NOMINATE scores computed from roll call votes from the 109th Congress, described in POOLE \& ROSENTHAL, supra note 25.

196 A logistic regression with robust standard errors was estimated to predict Republicans' votes on the motion (where the dependent vote variable codes a vote against tabling the amendment as a " 1 "). Because senators' ideology scores are available only through the 109th Congress, there are no scores for ten senators (nine Democrats and one Republican) who first assumed office in the 110th Congress upon being elected in November 2006. The text discusses the estimation excluding ideology, which includes all voting Republican senators. But as indicated in Table 8, if included, the ideology variable is insignificant, and there is no difference in significance level of any variables across the regressions estimated with or without the ideology variable.

197 Of the twelve senators cosponsoring deregulatory SOX legislation in either the 109th or 110 th Congresses, only one did not vote against the motion to table, Senator Bond, who had signed on to a bill in the 109th but not in the 110th Congress. This intuitive result is not inconsistent with the literature on cosponsorship finding an absence of correlation between cosponsorship and voting outcomes, see Wilson \& Young, supra note 84, as that research examined aggregate, not individual, voting and cosponsorship. 
of variables proxying for small-firm constituents in the analysis of the Senate vote is consistent with the media literature's identification of an information channel between regional newspapers, whose coverage reflects the interests of constituents, and elected officials. Namely, senators appear to have responded to the issue regional newspapers' relative coverage suggested would matter most to their constituents-SOX's adverse impact on small firms.

Before turning to compare the Senate vote to the action on SOX in the House, it should be noted that capital-market competitiveness was not totally disregarded in the floor debate on the America COMPETES Act, but the issue was not associated with SOX. A resolution was unanimously added to the bill, sponsored by Senators Charles Schumer and Mike Crapo (a Republican from Idaho who was a member of the Banking Committee and who was designated the chairman of a newly created Republican Party Capital Markets Task Force in August 2007), to express the Sense of the Senate that U.S. capital markets were losing "their competitive edge."198 The resolution referenced the McKinsey Study and urged state and federal regulators to coordinate activities to not adversely affect "innovativeness" or "impose regulatory costs that are disproportionate to their benefits," but the resolution made no reference to SOX as a target of regulatory action. ${ }^{199}$ The omission is probative regarding legislators' relative weighting of the SOX critiques because this was the same bill as the one Senator DeMint sought to amend to exempt small firms from SOX. It is therefore reasonable to conclude that legislators would appear to be more attuned to small-firm issues than to capital-market competitiveness ones when it comes to thinking about SOX, contrary to what a reader might reasonably intuit from reading solely the New York-based national press or national journalists. ${ }^{200}$

198153 CONG. REC. S5064 (daily ed. Apr. 25, 2007). For the creation of the task force and Senator Crapo's appointment as chairman, see Sen. Mike Crapo, The Republican Capital Markets Task Force, http://crapo.senate.gov/republican_capital_markets_task_force.cfm (last visited Mar. 23, 2009). The task force references both the Capital Markets Committee and Chamber Commission reports, among others, as identifying regulatory problems adversely affecting U.S. market competitiveness.

199153 CONG. REC. S5064 (daily ed. Apr. 25, 2007). At the same time that the resolution instructed Congress to exercise "vigorous oversight" to eliminate excessive regulation, it also admonished legislators to ensure investor protection was not compromised. Hence, similar to the DoddShelby resolution, the resolution on market competitiveness contained what appear to be conflicting objectives. This suggests that it too was an exercise in symbolic politics in which legislators expressed empathy to constituents' problems without taking concrete steps to alleviate them.

200 It seems unlikely that the motivation for the Senate action on SOX, in contrast to that of the House, was a perceived need to act on small-firm costs before the 2008 election in response to the SEC's position that it would not further delay section 404's implementation for small firms. That is because, in contrast to the House amendment, neither of the competing Senate amendments was cast in terms of deferring implementation for small firms for another year, as would be expected if doing something for small firms before an election was a pressing concern. Moreover, there was no difference in voting for the DeMint amendment according to whether or not a senator was up for reelection. 


\section{b. House}

The legislative action in the House of Representatives, which was less intricate procedurally than that of the Senate, provides an even more compelling case for the centrality of small-firm issues over market competitiveness for legislators. On June 28, 2007, the House passed the 2008 fiscal year appropriations bill for financial services and general government, which covered outlays for the SEC. ${ }^{201}$ During the floor consideration, the bill was amended to prohibit the SEC from expending any appropriated funds on enforcing section 404 against small firms - the non-accelerated filers who would otherwise have to start complying with the section by December 2007. The amendment was offered by Representative Scott Garrett, a Republican from New Jersey, and it was adopted by a vote of 267 to $154 .^{202}$ It was supported by nearly all Republicans (one Republican voted against it), and a significant number of Democrats (seventy-four, which was $32 \%$ of the caucus). Two weeks earlier, Representative Garrett had introduced a bill, with forty-two original cosponsors, to similar effect, that would have imposed a one-year moratorium on small firms' compliance with section $404 .^{203}$

Representative Garrett placed in the record three letters in support of the amendment, one of which was from the Chamber of Commerce. ${ }^{204}$ Of the organizations that had issued reports critical of SOX, the Chamber is the only one with a lobbying operation, and the amendment was consistent with, albeit far more modest than, its commission's recommendations on section 404 . Representative Frank, the chair of the committee with jurisdiction over the SEC, opposed the amendment, and paralleling Senator Dodd's position against the DeMint amendment, noted that SEC Chairman Cox had stated the SEC was "fixing" the problem and that legislation was unnecessary. ${ }^{205}$ The AFL-CIO once again sent a letter opposing the amendment. This time it was widely disseminated to legislators rather than solely to the leadership of the committee

201 Financial Services and General Government Appropriations Act, 2008, H.R. 2829, 110th Cong. (2007).

202153 CONG. REC. H7397 (daily ed. June 28, 2007) (Roll No. 588).

203 Small Business SOX Compliance Extension Act, H.R. 2727, 110th Cong. (2007). Representative Tom Feeney, a Republican from Florida, a cosigner of the bill, cosponsored the amendment with Representative Garrett (R-N.J.). 153 CONG. REC. H7323 (daily ed. June 27, 2007). By the time of the vote on the amendment, the original bill had fifty cosponsors. Although only one of the original cosponsors was a Democrat, with 20 percent of the Republicans signing on to the bill at the outset and two more Democrats joining a week later, the House leadership would have been aware of the considerable support among legislators for small-firm relief from SOX.

204 The other organizations advocating a vote for the amendment were the National Taxpayers Union and Property Casualty Insurers Association of America. 153 CONG. REC. H7324 (daily ed. June 27,2007$)$.

205 Id. at $\mathrm{H} 7325$ (remarks of Rep. Frank). 
with jurisdiction over the SEC. ${ }^{206}$ When a voice vote on the Garrett amendment was declared to have gone against it, Representative Garrett requested a recorded vote. ${ }^{207}$ That vote was postponed at the discretion of the chairman under House rules, ${ }^{208}$ and when the proceeding on the request for a recorded vote resumed the following day, the amendment passed.

The Senate-approved version of the appropriations bill did not include a spending limitation, which, along with other differences in the bills, created a conflict between the chambers. But in testimony to the House Small Business Committee in mid-December 2007, SEC Chairman Cox stated that he would propose delaying section 404's implementation for small firms for another year in order to undertake a staff cost-benefit study of the provision. ${ }^{209} \mathrm{He}$ thus acceded to the House's position regarding deferral of small firms' compliance with section 404 , as expressed in the spending prohibition, retracting his prior insistence that implementation not be postponed.

Shortly after Chairman Cox's testimony, an omnibus spending bill was approved by both chambers that included the SEC's 2008 appropriation without the Garrett amendment. ${ }^{210}$ However, the legislation was accompanied by an explanatory statement, as is common with authorization bills, which had the effect of codifying the postponement by referring to the agency's decision to delay implementation. ${ }^{211}$ Further underlining legislators' sensitivity to small

206 Letter from William Samuel, Director, Department of Legislation, AFL-CIO, to Representatives (June 27, 2007), available at http://www.aflcio.org/issues/legislativealert/alerts/upload /GarrettFeeneyAmendmentToHR2829.House607.pdf.

207153 CONG. REC. H7327 (daily ed. June 27, 2007).

208 Id. The Acting Chairman announced that the recorded vote was postponed under clause 6 of House rule XVIII. That rule gives the chairman discretion, when the House is deliberating as the Committee of the Whole House, to postpone a request for a recorded vote on an amendment. See RULES OF THE HOUSE OF REPRESENTATIVES, R. XVIII, cl 6, 110th Cong. (2007), available at http://www.rules.house.gov/ruleprec/110th.pdf.

209 Floyd Norris, S.E.C. Planning To Delay Accounting Rules for Small Companies for Another Year, N.Y. TIMES, Dec. 12, 2007, at C4. Chairman Cox fulfilled his pledge to the committee with the agency's proposal of an additional year-long extension from complying with the auditor attestation requirement of the statute for non-accelerated filers on February 1, 2008. Internal Control over Financial Reporting in Exchange Act Periodic Reports of Non-Accelerated Filers, 73 Fed. Reg. 7450 (Feb. 7, 2008) (to be codified at 17 C.F.R. pts. 210, 228, 229, 249). The rule was adopted on June 26, 2008. Internal Control over Financial Reporting in Exchange Act Periodic Reports of NonAccelerated Filers, 73 Fed. Reg. 38,094 (July 2, 2008) (to be codified at 17 C.F.R. pts. 210, 228, 229, 249).

210 Consolidated Appropriations Act, 2008, H.R. 2764, 110th Cong., Pub. L. No. 110-161,

121 Stat. 1844 (2007).

211 The proviso read:

The Appropriations Committees are concerned about costs that may confront small businesses complying with section $404 \ldots$. Therefore, the Committees are supportive of the recent decision by the SEC to delay for an additional year the requirement for an auditor's attestation of management's assessment of internal controls. The Committees understand that the SEC is collecting cost data and will assess the data to determine whether the current guidance and standards, approved in May 2007, pose an unreasonable financial burden on small businesses.

The SEC is directed to solicit the views of affected small businesses during this process.

STAFF OF H. COMM. ON APPROPRIATIONS, 110 TH CONG., CONSOLIDATED APPROPRIATIONS ACT, 2008, at 905 (Comm. Print 2007). 
firms, the report also instructed the SEC to direct its Office of Small Business Policy to serve as an "ombudsman" for small business, "to help them face the joint challenge of meeting section 404 compliance deadlines with untested riskbased regulation." 212 The report assigned the Office to solicit comments from small businesses and to publicize "their concerns within the Commission to assure that the needs of small business are reflected in the Commission's rules, and in [its] interpretations and guidance."213

The legislative tactic of instructing agencies regarding specific expenditures outside of explicit statutory language is not as unusual as it might appear. There is a rich tradition of non-statutory directives accompanying budget legislation. Appropriations committees have, indeed, more commonly used this strategy than statutory spending prohibitions to regulate agency action. ${ }^{214}$ Such "extralegal techniques" are not hortatory, but rather have genuine bite. ${ }^{215}$ Appropriations committees prefer them both because they are efficient-they "reconcile detailed control with administrative flexibility"and also because they maintain control over the agency in the appropriations committees rather than the legislative committees with jurisdiction. ${ }^{216}$ The latter feature takes on special significance in the SOX context, as the legislative committees with jurisdiction over the SEC had demonstrated a strong aversion to moving on SOX. The Senate Banking Committee Chairman had already expressed opposition to providing legislative relief for small firms from SOX in opposing the DeMint amendment, ${ }^{217}$ and the Chairman of the House Financial Services Committee was of an apparently similar disposition. The

212 H. COMM. ON APPROPRIATIONS, supra note 211, at 905.

$213 \quad I d$.

214 MiChael W. Kirst, Government Without Passing Laws (1969). In the 1970s, when the number of spending limitation amendments or "riders" greatly increased as representatives attempted to force legislative action on social issues that were being blocked in authorizing committees, such as abortion and busing, the rules were altered to limit such amendments and provide greater control to the majority party leadership. OLESZEK, supra note 179 , at 56 .

215 KIRST, supra note 214 . The appropriations committees have a range of sanctions to apply if an agency ignores a directive included in a committee report or made at a hearing. These include nonstatutory actions, such as issuing rebukes to officials in hearings, and undertaking punitive investigations, and statutory actions, such as cutting future funding, adding punitive provisos (objectionable restrictions on use of funds), and use of detailed line items rather than lump-sum appropriations. Id. at 73-79; see OLESZEK, supra note 179, at 298-300.

216 KIRST, supra note 214, at 155 . Not being a member of the Appropriations Committee, Representative Garrett was not in a position to influence the agency's action through the alternative, nonstatutory appropriations oversight techniques. Although he was a member of the Financial Services Committee, the opposition to the amendment by the Chairman, Barney Frank, made plain that the prospect for obtaining small-firm relief from the SEC through that Committee's oversight channel was nil. Accordingly, the amendment in the form of a statutory prohibition on expenditures was his most effective avenue for attaining his objective of small-firm relief from section 404's impending implementation.

217 The Chair of the Senate Committee on Small Business and Entrepreneurship, Senator Kerry, was one of that amendment's most vocal opponents: although he was not actually present for the debate, he entered a lengthy written statement objecting to the amendment into the Congressional Record. 153 CONG. REC. S4898 (daily ed. Apr. 24, 2007). 
appropriations bill maneuver had the effect of boxing in both the SEC and the oversight committees.

The House vote is by far a more intriguing development than the Senate one, not only because it passed, but also because the House Democratic Party leadership, along with a majority of the caucus, opposed the amendment, and conventional wisdom holds that differences in the chambers' institutional practices enables the controlling party to exercise far greater agenda control in the House. ${ }^{218}$ Given that SOX-related bill introductions were for all practical purposes a Republican initiative, it would seem to be rather surprising that the House was the chamber in which a SOX restriction passed.

Several differences in the circumstances of the votes in the two chambers, however, would appear to have contributed to the greater level of Democratic support to take action on SOX in the House than in the Senate. First, the House vote on the amendment was substantive, not procedural, so that the import of a negative vote would be more transparent to constituents, rendering party discipline more difficult to enforce. This is significant because research on media coverage of representatives' legislative activities indicates that roll call votes are the most extensively reported activity. ${ }^{219}$ Second, Representative Garrett's amendment's substance was far more modest than Senator DeMint's amendment, as it called for a delay in, rather than elimination of, section 404's applicability to small firms. Third, the SEC's revised guidelines had been released by the time of the House vote and were viewed by many as inadequate for mitigating small firms' costs.

A fourth factor distinguishing the legislative response across the chambers is the support of the Garrett amendment by the chair and a majority of the Democrats on the Small Business Committee. Political scientists have noted that a successful strategy of opponents of the status quo is issue expansion by means of venue-shopping, whereby an issue is redefined to be within the jurisdiction of a political institution different from the issue's current guardian. ${ }^{20}$ SOX's critics in the House were able to use this approach successfully and shift the forum away from the congressional committee with jurisdiction over the agency, the Financial Services Committee, whose members were blocking any tampering with the status quo. The SOX critics in the House worked the statue's financial burden on small firms as the rationale for change through the Small Business Committee-whose members are

218 See, e.g., OLESZEK, supra note 179, at 319; SMITH ET AL., supra note 10, at 234. Only one member of the House Democratic leadership voted for the amendment, Tennessee Representative Tanner, who is one of the party's eight chief deputy whips. Although the amendment process is generally more restrictive in the House than the Senate, SMITH ET AL., supra note 10, at 219-20, 224-26, the appropriations bill was considered under an open rule, as is the norm for such legislation, OLESZEK, supra note 179, at 129. That convention, as well as the support of key Democrats on the Small Business Committee, limited the Democratic leadership's ability to maneuver so as to prevent Representative Garrett's offering of the amendment.

219 See ARNOLD, supra note 114, at 121-22, 154.

220 FRANK R. BAUMGARTNER \& BRYAN D. JONES, AGENDAS AND INSTABILITY IN AMERICAN POLITICS (1993). 
focused on small-firm issues and have no ongoing relation with the SEC - and were able to latch onto appropriations legislation outside of the Financial Services Committee's gatekeeping purview. A venue-shopping strategy did not present itself in the Senate because, as earlier noted, the chair of the parallel committee in the Senate opposed the DeMint amendment, and in the legislative maneuvering the committee with jurisdiction was able to retain control of the issue. $^{221}$

Finally, it should be noted that the House's successful action on SOX, in contrast to that of the Senate, is consistent with the political science literature identifying an electoral connection with issue salience: the House is considered to be more closely attuned to public sentiment because the biennial election of all members provides its leaders and membership with a greater incentive to be responsive to constituents. ${ }^{222}$ Without the postponement of the statute's applicability that would be affected by the Garrett amendment, small firms would have had to begin preparing to meet the statute's auditor attestation requirement prior to the upcoming 2008 election. Consequently, Democrats wishing to demonstrate responsiveness to small business concerns were left with no obvious option other than supporting the Garrett amendment in order to obtain for their constituents a favorable, albeit modest, resolution of the issue before the election.

Table 7 provides a comparison of personal and district characteristics across Democrats by how they voted on the Garrett amendment. It is telling, and consistent with the literature's emphasis on an electoral connection, that both greater reelection concern and closer connections to small business would appear to matter. Similar to differences across Senate Republicans voting against tabling for the DeMint amendment, the House Democrats who voted for the Garrett amendment had been in office significantly fewer years, were more likely to be serving their first terms in office, and had been elected by significantly smaller margins. Supporters of the amendment also received more campaign contributions from small business lobbying associations, the proxy used in the House vote analysis for small business constituents. ${ }^{223}$ In contrast to the Republican Senate voters, however,

221 Because the Senate Small Business Committee Chair, like his House counterpart, had sought a delay in section 404's implementation for small firms, see supra note 172 and accompanying text, it is possible that he would not have opposed a Senate amendment phrased as a postponement rather than a permanent exemption for small firms.

222 See, e.g., Robert S. Erikson \& Gerald C. Wright, Voters, Candidates, and Issues in Congressional Elections, in CONGRESS RECONSIDERED 91, 111-12 (Lawrence C. Dodd \& Bruce I. Oppenheimer eds., 5th ed. 1993) (suggesting that although the same electoral connection impact on representation exists in both chambers, there is more latitude in Senate voting, as the evidence indicates senators respond to the six-year election cycle, moving closer to constituents in the year or two before the senator must run again).

223 The business associations category as defined by the Center for Responsive Politics includes contributions from the U.S. Chamber of Commerce, local chambers, and the National Federation of Independent Business, an "advocacy organization" of small businesses. See National Federation of Independent Business, http://www.nfib.com/page/about (last visited Mar. 23, 2009). The 
there is a statistically significant, ideological difference across the Democrats voting in the House: Democratic supporters of the amendment were more conservative than Democratic opponents, whether measured by the ideology score computed from roll call votes or by membership in the Blue Dog Coalition, a group of self-identified conservative and moderate Democrats. ${ }^{224}$

The ideological differentiation of Democrats' voting on the amendment suggests that many of the provision's supporters represented swing or relatively conservative districts. These Democrats may well have been apprehensive that they might be subject to a greater electoral threat were they not to support small business on an issue important to those constituents. Consistent with such an interpretation, a recent study of local newspaper coverage of members of Congress found that those whose votes are "out of step" with their constituents receive significantly more, and less positive, coverage, than those who are "in step."225 A plausible inference is that the House leadership did not wish to enforce party discipline on the Garrett amendment vote, which concerned an issue at the periphery of the party's agenda and could have increased the likelihood of weakening their control of the Chamber. ${ }^{226}$

Table 8 reports the multivariate regression results for the House Democrats' votes on the Garrett amendment. The data are consistent with the hypothesized electoral connection, and hence, the salience afforded small-firm issues in the regional press. Democrats less secure in their seats-more recently

contribution data for those organizations were obtained from the Center's website, OpenSecrets.org, Lobbying Spending Database Business Associations, 2009, http://www.opensecrets.org/lobby /indusclient.php? Iname=N00\&year=a (last visited June 9, 2009). Because the source identifying business establishments does not line up with their location in congressional districts, that variable is not used in the analysis as the proxy for small business constituents. The analysis reported in the text was also undertaken using a dummy variable indicating whether there was a local chamber of commerce (from those identified for the analysis of the Senate vote, see note 193, supra) in a city in which the representative had an office (identified from the representatives' websites), as an alternative measure of the strength of small business constituents. It was insignificant (unreported regressions).

224 As discussed in note 197, supra, the DW-NOMINATE scores are available only for legislators who held office as of the 109th Congress, a total of 182 Democrats (49 voting for and 133 against the amendment) and 181 Republicans. Membership in the Blue Dog Coalition was identified from its website. Blue Dog Coalition, http://www.house.gov/melancon/BlueDogs/ (last visited Mar. 23, 2009). Only one member of the Blue Dog Coalition is a member of the Democratic Party leadership, Representative Tanner, who was the only member of the leadership to vote for the amendment.

225 Brian J. Fogarty, The Strategy of the Story: Media Monitoring Legislative Activity, 33 LEGIS. STUD. Q. 445, 459-63 (2008). Because newspapers whose circulation lies within a congressional district-referred to as the "congruence" of a district's press coverage-are more likely to cover a representative's activity, Snyder \& Strömberg, supra note 115, at 3-5, I also included in the House vote regressions a variable measuring the representatives' districts' congruence. It was not significant (unreported regressions).

226 Maintenance of chamber control is a key concern of party leaders. A principal approach for doing so is to demand party loyalty on key procedural votes, with the leadership contending that doing so will maintain (or achieve) the party's control. See OLESZEK, supra note 179, at 322. The Garrett amendment was not, however, a procedural vote. It is possible that the Democratic leadership perceived its hold on the House to be weaker than its hold on the Senate. A large number of the newly elected Democrats' seats were up in what had previously been Republican-represented districts, where small business constituents' concerns could well be important. The situation in the House contrasted dramatically with that of the Senate, where there were relatively few Democratic seats up for reelection in 2008 . 
elected members or those elected by a narrower margin-were more likely to vote for the provision. In addition, those more closely associated with organizations supporting small business-recipients of higher contributions from associations representing small businesses and members of the House Small Business Committee-were more likely to vote for the amendment.

\section{Prognosis on SOX}

Revamping legislation in the United States is conventionally thought to be difficult given the multiple actors and veto points in the legislative process. Still, substantial amendments do occur: a recent study found that slightly over half of "major" statutes enacted from 1954 to 2001 were significantly amended, on average five years after enactment. ${ }^{27}$ Casual empiricism suggests, however, that with regard to financial-market regulation, Congress does not move rapidly to alter statutes widely perceived to be flawed, and five years would appear to be speedy for a major amendment in this area. That phenomenon bears importantly on evaluating the prospects of SOX's recrafting and for drawing lessons from SOX for efforts to draft a new regulatory architecture for financial institutions.

\section{A. The Path of Legislative Revisions}

The most pertinent template providing helpful insight for prognosticating the probability of SOX's recrafting is the Foreign Corrupt Practices Act (FCPA) of 1977. 228 This statute has a regulatory objective similar to that of SOX: the adequacy of public companies' internal controls. Paralleling SOX, the FCPA was adopted with minimal opposition following a high-profile accounting scandal-the revelation that while doing business abroad, hundreds of firms had paid foreign officials hundreds of millions of dollars not disclosed in their financial statements. ${ }^{229}$ The FCPA made illegal all but certain de

227 Maltzman \& Shipan, supra note 116, at 258. The list of "major" statutes and "significant" amendments is taken from David Mayhew's identification of such legislation. See DAVID R. MAYHEW, DIVIDED WE GOVERN: PARTY CONTROL, LAWMAKING, AND INVESTIGATIONS, 1946-2002, at 52-73 \& tbl.4.1 (2d ed. 2005). The Foreign Corrupt Practices Act, which is a statute similar in content to SOX, is not included in the study. Maltzman and Shipan count as amendments only those included in Mayhew's list of major statutes-those he considered to be "significant" amendments-so as to eliminate technical and minor amendments, noting that virtually all laws experience inconsequential amendment. Maltzman \& Shipan, supra note 116 , at 258.

228 Foreign Corrupt Practices Act of 1977, Pub. L. No. 95-213, 91 Stat. 1494 (1977) (codified as amended at 15 U.S.C. $\S \S 78 \mathrm{dd}$ to $\mathrm{dd}-3$ (2006)).

229 A. Fremantle \& S. Katz, The Foreign Corrupt Practices Act Amendments of 1988, 23 INT'L LAW. 755 (1989). There are, however, differences in the enactment environments of SOX and the FCPA which need to be noted. First, the stock market was not in free fall when the FCPA was enacted. There had been a large decline in 1973 to 1974 during the Watergate crisis, of which the "sensitive" payments accounting scandal was a part, and thereafter the market trended up, with a minor decline in October 1977 when the statute was being considered. Second, the FCPA was not adopted in the midst of the crisis. When the scandal broke in 1974, Congress requested the SEC to undertake an investigation 
minimis payments to foreign officials, including payments to third parties that ended up in government hands, and imposed accurate reporting and internal controls requirements on public companies.

Shortly after the FCPA was enacted, the business community began voicing concern over ambiguity in the statutory language regarding what constituted illegal conduct, and questions were raised about the cost of the new accounting requirements, along with uncertainty in the scope of enforcement. Small firms were the most negatively impacted by the statute, particularly the third-party payment provisions. Because they did not have the resources to operate abroad directly, small exporters used foreign agents and were therefore exposed to liability for actions taken by third parties whom they did not control. ${ }^{230} \mathrm{~A}$ focused effort to revise the legislation began in earnest with the election of President Ronald Reagan, as improving U.S. firms' global competitiveness was a core issue of his Administration and revising the FCPA was a priority in that agenda. The departing SEC Chairman attempted to mitigate the objections to the FCPA by releasing a policy statement in January 1981 emphasizing "reasonableness" in implementation and enforcement, ${ }^{231}$ a move strikingly analogous to the contemporary SEC's issuance of clarifying guidance on section 404's implementation. That effort failed, however, to allay perceived difficulties with the statute.

Immediately after taking office in 1981, the Reagan Administration began seeking congressional amendment of the FCPA, advocating not only redrafting to eliminate uncertainty but also repeal of criminal penalties. ${ }^{232}$ Senator John Chafee, who had introduced legislation to revise the FCPA prior to the election, reintroduced his bill in February 1981, which did not include elimination of criminal sanctions. A similar bill was introduced simultaneously in the House. The Republican-controlled Senate passed Senator Chafee's bill (by voice vote) in November 1981, but it stalled in the Democratic-controlled House (where a key legislator, the chairman of the subcommittee with jurisdiction, was adamantly opposed to tampering with the legislation).

Bills to amend the FCPA to resolve business concerns were introduced in each succeeding Congress (1983, 1985, 1987), and a modest revision was finally accomplished as an amendment to omnibus trade legislation in $1988 .^{233}$

that took two years to complete, and the legislation was enacted eighteen months after Congress received the SEC's report on its investigation. Id. at 755-56. Finally, the FCPA was not considered in an election year. These differences, underscoring the FCPA's lengthier gestation, would all suggest that there would have been greater care and hence most likely fewer unintended consequences-and hence greater stability-to the FCPA than SOX.

230 Gray, supra note 12, at 14.

231 Foreign Corrupt Practices Act of 1977, 46 Fed. Reg. 11,544 (Feb. 9, 1981).

232 In contrast to his predecessor, John Shad, the Reagan administration's nominee for SEC Chairman, supported congressional legislation to revise the statute. J. Gerth, Shad: Ease Regulations, N.Y. TimEs, Apr. 7, 1981, at D6.

233 Fremantle \& Katz, supra note 229 , at 759 . By the time it was enacted the bill had seventeen cosponsors, two of whom were Democrats. Although there are references in the literature to the Senate's having passed another such bill in 1983, e.g., Gray, supra note 12, at 15 , I was unable to identify such action in the congressional record. 
The amendment revised the FCPA's accounting and bribery provisions, addressing business concerns regarding recordkeeping costs and third-party payment liability under FCPA. These costs affected all firms but were, as legislators noted in supporting the amendments, especially important to small firms. ${ }^{234}$ Although the Republicans by then no longer controlled the Senate, support for recrafting the legislation was so overwhelming that the amendment could not be stopped by its few, albeit influential, Democratic opponents. These opponents included Senator William Proxmire, the Senate Banking Committee Chairman (a leading sponsor of the FCPA), and Senator Timothy Wirth, the former House subcommittee chairman who, after years of successfully bottling up the statute's amendment in the House, had recently been elected to the Senate.

Another apt example of the sluggish course of legislative revision of financial regulation, although further afield from SOX in substantive content than the FCPA, is the Glass-Steagall Act, the New Deal legislation that separated commercial and investment banking. It is instructive that, despite withering critiques and efforts to undo the statutory separation, the Act took decades to repeal. Repeal only occurred in the aftermath of the banking debacle of the $1980 \mathrm{~s}$, with awareness that the regulatory setup had contributed to the crisis and reduced U.S. banks' competitiveness, and the accumulation of research indicating that banks' combined activities had not been responsible for the 1930s' financial difficulties and that universal banking did not adversely affect the economies of the many nations permitting it. ${ }^{235}$

\section{B. Prospects for the Recrafting of SOX}

Under what circumstances might SOX be revised, given what can be intuited from the path of the FCPA as well as the congressional responses to the SOX critiques? In brief, if revision is not to take a similarly glacial pace as that of the FCPA or that of the Glass-Steagall Act, then the occurrence of one of two seemingly formidable tasks would appear to be a pre-requisite: (1) a seismic shift in the political environment in which the Republican party regained control of the federal government or (2) establishment of a link, in the public mind-and hence the attention of Democratic party legislatorsbetween the need to revise SOX and the solution to a continuing recessionary economy.

234 See, e.g., 134 CONG. REC. 20,024 (1988) (remarks of Sen. Sanford) ("[T]he bill brings some much needed clarification to the operation of the Foreign Corrupt Practices Act. This clarification is essential if companies, particularly small businesses, are to behave competitively, but legally, in foreign markets."); id. at 19,925 (1988) (remarks of Sen. Dixon) ("The only thing that is added [by the conference report regarding the FCPA] is greater clarity. The only thing missing is the chilling effect that currently prevents many small businesses from even attempting to do business overseas.").

235 Barth, Brumbaugh \& Wilcox, supra note 13. Prior to repeal by the Gramm-Leach-Bliley Act of 1999, Pub. L. No. 106-102, 113 Stat. 1338 (1999), banking regulators had chipped away at the separation. Id. at $196-97$. 


\section{The Prospective Impact of Changes in the Political and Economic Environment}

The 2007 congressional votes indicate that a decisive majority of the Republican party is willing to revise a key provision of the statute, but only a small number of Democrats, most of whom represent swing districts, are likeminded. If this pattern were to persist, given the multiple veto points in the legislative process, the Republicans would seem not only to need to regain the executive branch but also to recapture both chambers of Congress to ensure that revising SOX moves up on the legislative agenda. That scenario would suggest that revision would not occur, at best, until after the next presidential election given the Democrats' control of both the executive and legislative branches following the 2008 election. ${ }^{236}$

It is true that, despite a Congress controlled by Democrats, the FCPA was revised under the Reagan Administration. But as earlier mentioned, that revision took years to accomplish, along with a fortuitous event, the departure from the House to the Senate of a key Democrat, Timothy Wirth. Moreover, there was broader bipartisan support for FCPA revision in the Senate early on, compared to the Senate support for revising SOX, as a bill to amend the FCPA had passed the Senate without opposition by Democrats in the first year of the Reagan Administration.

The legislators who led the opposition to amending the FCPA were the statute's sponsors. One might therefore expect that the retirements of Senator Sarbanes and Representative Oxley could ease the way for amending the statute, accelerating the time frame compared to that of FCPA reform. However, individuals closely associated with the statute's namesakes, who are, in all likelihood, committed to maintaining the statute in its current form, are still in positions of influence and could restrain other legislators who might otherwise be receptive to tweaking SOX. Members of Senator Sarbanes' staff, for instance, continue to work for Congress, and one has been appointed to the PCAOB, which, as earlier noted, can impede SEC efforts to revise SOX. ${ }^{237}$

236 It is instructive that the Democratic party's 2008 election platform advocated expansion of government spending programs to improve competitiveness, rather than deregulation, and its specific proposal for small business made no reference to SOX. 2008 Democratic Party Platform, http://www.democrats.org/a/party/platform.html (last visited Apr. 5, 2009). In addition, President Barack Obama voted to table the DeMint amendment when he was a senator, along with virtually all other Democrats. It should be noted that the Republican party platform also made no reference to SOX, but it did include a plank advocating elimination of frivolous litigation as a means of improving U.S. competitiveness, a priority mentioned in three of the commissioned reports, those of the Chamber Commission and Capital Markets Committee, and the McKinsey Study. 2008 Republican Platform, http://www.gopplatform2008.com/2008Platform.pdf (last visited Sept. 2, 2008).

237 See SEC Taps Former Sarbanes Aide To Fill Vacancy on Auditor Oversight Panel, 40 Sec. Reg. L. Rep. (BNA) 920 (June 9, 2008) (former chief counsel of the Senate Banking Committee, who had worked under Senator Sarbanes on the Committee for fifteen years, appointed to PCAOB board by SEC Chairman Cox); supra note 53 and accompanying text (disagreement between the SEC and PCAOB said to have prevented the SEC from exempting small firms from at least part of section 404). Senator Sarbanes' staff's retention of positions on the Banking Committee or other legislators' staff would enable them to exert influence on the statute's future by, for example, constraining SEC 
An exogenous factor affecting whether any revision would be accomplished without Republican political control is the state of the economy. If the deteriorating state of the economy in conjunction with the 2008-2009 financial crisis could be linked in the public's mind to SOX, then it could be politically perilous for legislators of any party to oppose its revision, even though experience would suggest that congressional activity in response to economic declines or crises often produces the precise opposite-an increase, not decrease, in regulation. ${ }^{238}$ Concerns most salient to the public during a downturn, such as deteriorating employment or wages, and in the current crisis, declining housing prices as well, would seem to be problematic for drawing a link between SOX and economic hard times. None of those concerns are easily connected to the position of small firms and stock exchanges being adversely affected by SOX.

There is also no self-evident connection between costs imposed by SOX and the cascading credit crunch following the subprime mortgage crisis. That absence of linkage has a double-edged import. The crisis has not generated a backlash against the critiques of SOX, but has displaced congressional effort to revise SOX by redirecting legislators' attention to matters related to financial intermediaries. The policy agenda appears to be importantly affected by legislators' "selective attention," because of the limits on the capacity of human cognitive processes, which result in individuals' being able to "attend to only limited elements of the environment at any given time., 239

Nonetheless, as the economy deteriorates, assisting small firms by reducing SOX's burdensome costs may well reemerge as an issue. Such a possibility is suggested by an editorial in the San Francisco Chronicle, one of whose authors is a prominent, and influential, political entrepreneur, former Republican Speaker of the House, Newt Gingrich. The editorial called on Congress, "with signs that [the] economy is moving toward recession," to repeal SOX, which was described as "undermining the venture-capital industry in Silicon Valley." 240 In making its case, the editorial picked up on both the

commissioners' official positions through inquiries in the nomination process requiring expression of support for SOX. I would like to thank Professor Donald C. Langevoort of Georgetown University Law Center for pointing out this connection in remarks at the RIETI International Seminar on Lessons from SOX Act and Perspectives on J-SOX, in Tokyo, Japan on June 25, 2008.

238 Romano, supra note 15, at 1591-94.

239 JONES \& BAUMGARTNER, supra note 28 , at 16 . The reform proposals variously mentioned have been directed at regulation of the residential mortgage lending process and of financial institutions, or provision of financial assistance to homeowners and to financial institutions. Small-firm concerns have appeared in the form of congressional urging of the Small Business Administration (SBA) to increase loans to small businesses. See, e.g., Press Release, House Small Business Committee, Fed and Treasury Provide Assistance to Small Business, (Nov. 25, 2008) (news release from Committee Chair praising Fed and Treasury's creating facility to support SBA loans, in response to Committee hearing and letter pressing Treasury to help small businesses having difficulty obtaining loans from the SBA).

240 Newt Gingrich \& David W. Kralik, Op-Ed., Repeal Sarbanes-Oxley, S.F. CHRON., Nov. 5,2008 , at B17. A recent op-ed in the Wall Street Journal coauthored by a Silicon Valley executive and journalist, similarly placed repeal of SOX as the top priority for reviving the economy. Tom Hayes \& Michael S. Malone, Op-Ed., Entrepreneurs Can Lead Us out of the Crisis, WALL ST. J., Feb. 24, 2009, 
small-firm and market-competitiveness critiques of the statute. ${ }^{241}$ Rallying the venture capital sector to reinvigorate efforts to revise SOX is a strategy in sync with the pattern of media coverage of the SOX critiques that attracted congressional response. It should also be recalled that the San Francisco Chronicle not only ran relatively more stories on small-firm costs than stock market competitiveness, but also ran market competitiveness stories that tended to cover the cost of going public for domestic firms, a matter of substantial concern to venture capital, rather than the foreign-firm slant emphasized by other papers. ${ }^{242}$ Moreover, the concerns of Silicon Valley firms and their venture capitalist financiers are matters likely to generate bipartisan political support from the California delegation.

More important from the perspective of connecting SOX's revision to desirable economic policy, the significance of vibrant small firms for economic growth has deeper implications beyond the immediate impact on the California economy. In a cogently reasoned book, William Baumol, Robert Litan, and Carl Schramm maintain that the crucial factor for economic growth and prosperity are entrepreneurs whose small business enterprises "undertake and commercialize radical or breakthrough innovations" that dramatically increase worker productivity and, accordingly, a nation's standard of living. ${ }^{243}$ They further contend that government policies that encourage the formation and maintenance of such innovative firms are critical for a nation's material wellbeing. ${ }^{244}$ Their analysis of the entrepreneurial small firm as an important engine of long-term economic growth suggests that good politics and good policy could work in tandem, especially in economic hard times, to recraft SOX. ${ }^{245}$

at A15. A subsequent staff opinion column voiced a similar theme, on the current problems for venture capitalists, asserting that SOX had "helped kill" the IPO market. L. Gordon Crovitz, Too Risky for Venture Capitalists, WALL ST. J., Mar. 2, 2009, at A13.

241 Gingrich has been involved in the creation of a grass roots organization, American Solutions, that engages in citizen mobilization on a broad range of national issues, and repeal of SOX is a focus of its financial market area activities. See American Solutions, http://www.americansolutions .com/About (last visited Mar. 23, 2009).

242 See supra note 145.

243 William J. BAumol, Robert E. LiTAN \& CARL J. SCHRAMM, GOOD CAPITAliSM, BAD CAPITALISM, AND THE ECONOMICS OF GROWTH AND PROSPERITY 85-88 (2007).

244 Among the policies emphasized as most important for doing so are protection of contract and property rights, including patent law, ease of business formation and exit (bankruptcy law), flexible labor laws, free trade and enforced, but not abused, antitrust laws. Id. at 95-121.

245 Baumol, Litan, and Schramm, in a nuanced discussion, view SOX as an issue that could be a drag on economic growth. In analyzing what needs to be done to ensure that the United States maintains its entrepreneurial edge, they voice concern over SOX's potential disincentive for entrepreneurship by increasing the cost of being a public company. Id. at 240 . The concern is that SOX could discourage entrepreneurship by "dim[ming] . . prospects for profitable expansion" were a new firm to prove successful, because the potential returns from the risky enterprise could be significantly lowered: the key financiers of entrepreneurial firms, venture capitalists, will not be able to exit in a public offering, and the founders will not want to see the innovation through by staying with the firm after selling. $I d$. at $103,240-41$. They also believe that policymakers and the public view economic growth as a "cyclical" rather than "structural" problem, and hence would be more likely to consider adapting policies to foster innovation through small entrepreneurial firms in recessionary or crisis times. Id. at 272-74. 


\section{Predicting SOX's Revision by a Model Focused on Congressional Characteristics}

Forrest Maltzman and Charles Shipan have recently sought to predict when major legislation will be significantly revised. ${ }^{246}$ Rather than analyze the legislation's substantive content and the economic environment, their strategy is to focus on general features of the legislation and the enacting and postenactment Congresses to estimate the probability a statute will be amended over time. Maltzman and Shipan's model can be applied to SOX to offer another perspective on the likelihood of its revision.

The two congressional characteristics included in their model to estimate the probability of amendment are whether the President is of the same political party as the majority in either chamber (referred to as "unified" government when the parties are the same and "divided" government when they differ), and the degree of ideological disagreement or differences across the chambers. ${ }^{247}$ Two variables related to the legislation are also included: a statute's divisiveness (which refers to how contentious the vote on the statute was) and its complexity. ${ }^{248}$

The characteristics of the Congress that enacted SOX are ambiguous for predicting substantial revision: laws, such as SOX, enacted at a time of divided government are more likely to be amended but so are laws with larger chamber differences at enactment (which is not the case of SOX). ${ }^{249}$ Similarly ambiguous are the results regarding the legislation's characteristics. While both a statute's divisiveness and complexity increase the probability of amendment, only one of SOX's features, its complexity, works in the same direction as that associated with an increased probability of amendment. ${ }^{250}$

246 Maltzman \& Shipan, supra note 116 . Their study includes 262 statutes, enacted from 1954 to 2002, thus ending in the year SOX was enacted.

247 Id. at 260-62. The chamber ideological disagreement or difference is constructed from the difference between the level of voting support across the chambers on conference reports (identical legislation). These variables are measured for both the enacting and subsequent Congresses, and the chamber difference variable is interacted with time because diagnostic tests indicated that it had nonproportional effects. Id. at 260 .

248 Complexity is measured by the number of pages of the statute in the Lexis database. Divisiveness is the smaller of the percentage yea votes in the Senate or House on the vote on the statute's final enactment. Id. at 260. Maltzman and Shipan also estimated a second model, which added to those variables a dummy variable for whether the statute was expiring under a sunset provision, to make sure that such a provision, mandating that a law "be amended or allowed to die," was not driving their results. $I d$. at 263 . The dichotomous variable takes on a value of 0 in all Congresses except the one in which the statute will expire without additional action, when the value is 1 .

249 Id. at 263 . The chamber difference for SOX was a minimal .03, which is more than a standard deviation below the mean value in the Maltzman and Shipan study of .06. Id. at 261 .

$250 I$ Id. at 262-63. With a value of 99 , SOX was not a divisive statute. SOX was above average in complexity-its page length of 79 is greater than the study's average of 39.9 . Yet that is considerably less than one standard deviation larger than the study average (which would be 125.6), and in terms of complexity's marginal effect, a statute "one standard deviation more complex than average [is] $17 \%$ more likely to be amended in the future." $I d$. at 262 . 
The import for predicting SOX's substantial revision of the post-SOXenactment congressional variables-divided government and ideological disagreement-is less ambiguous, indicating that the probability of amendment is increasing over time. Namely, the model indicated that the probability of amendment is lower the greater the subsequent chamber difference (laws are more stable when the chambers are ideologically distinct because it would be more difficult to agree on revision), whereas the presence of divided government post-enactment had no impact on amendment. ${ }^{251}$ The level of chamber difference decreased steadily post-SOX, declining to .057 in 2007 from .098 and .093 in the 108 th and 109 th Congresses, respectively.

The increasing likelihood of the statute's revision is shown in Table 9, which reports the estimated probability of SOX's amendment obtained by applying the coefficients of Maltzman and Shipan's estimated model to the values of the variables in the post-SOX-enactment Congresses. ${ }^{252}$ As the Table indicates, by 2007 , the year of the congressional votes on SOX, the estimated probability of amendment increased substantially, from less than $10 \%$ to nearly one-third. It is noteworthy that the rising probability of amendment parallels the increasing number of bill introductions and cosponsorships, and hearings related to SOX, and is consistent with the political science literature's finding that an upswing in such congressional activity is correlated with an issue's forward movement in the legislative process. ${ }^{253}$

The Maltzman and Shipan results and the out-of-sample estimates for SOX reported in Table 9 suggest that what happens after a statute is enacted is more important for legislative durability than the conditions at enactment. ${ }^{254}$ Their findings and the Table estimates lend further support to the earlier analysis's emphasis on changing macro- political and economic circumstances as the key to SOX's future.

251 Id. at 262 . This value is below the mean subsequent chamber difference in the study of .08 by slightly more than one standard deviation. Id. at 261 . The subsequent divided government variable is insignificant in the study, and thus, the probability of amendment is not affected by whether there is unified government post-enactment (although Maltzman and Shipan had expected it to increase in such a setting). Post-SOX, until 2007, there was unified government.

252 In addition to the variables described in the text, Maltzman and Shipan's model includes other variables that were statistically insignificant in their study: public mood and court attention. The policy mood variable represents public support for liberal activist government, and was created by James Stimson, who converted public opinion poll data into scores. Id. at 260-62. Values for that variable are available at http://www.unc.edu/ jstimson/time.html, updated from JAMES A. STIMSON, PUBLIC OPINION IN AMERICA: MOODS CYCLES, AND SWINGS 37-66 (2d ed. 1999). The Table's estimated probability for 2008 uses the chamber difference variable's value from 2007 because the data needed to compute the variable- votes on conference reports identified by the House Final Calendar-are not yet publicly available.

253 See supra notes 174-176 and accompanying text.

254 This result is consistent with the Eric Patashnik's research on the durability of legislation characterized as major public interest reforms. He finds that these laws' durability is related to the timing of changes in the economic or macropolitical environment, and the making of extensive financial investments by private actors that support the new regime. ERIC M. PATASHNIK, REFORMS AT RISK 16169 (2008). 


\section{A Thought Experiment: If Revised, What Is the Most Probable Scope of Revision of SOX?}

The most readily imaginable short-term congressional action on SOX would seem to be a further extension of the postponement of section 404's applicability to the smallest firms. Such a provision would appear to be capable of enactment in the House because the Democrats' pick-up of twenty seats in the 2008 election is not sufficiently large to affect the margin of victory of the appropriations bill vote, assuming, of course, that the leadership would not seek or be able to block a vote. ${ }^{255}$ Moreover, reducing business costs is more likely to be a greater legislative concern in a recessionary economy. If the SEC's interpretive guidance on section 404 does not fulfill the stated intention of reducing compliance costs, particularly for small firms, the number of Senators willing to support a revision of SOX should be expected to increase as the Senate resolution that trumped the DeMint amendment expressed the view that the guideline revision would resolve the issue. But it is far from apparent that the level of senatorial support would reach a majority, let alone the magic number of sixty senators necessary to avoid a filibuster, especially given the reduced number of Republic senators.

In my judgment, the SEC's stated expectation regarding the efficacy of the revised guidance at reducing small-firm costs is not realistic. That is because the essence of the implementation cost problem involves external auditors' decisions, and auditors have been loathe to cooperate in implementing a more flexible interpretation of the regulations that would reduce certification costs. $^{256}$ The accounting firms' comment letters to the SEC's proposed guidance are instructive on this score: their responses suggest that they might not fully cooperate with the stated goal of a more flexible internal controls attestation process. ${ }^{257}$ They would appear to prefer having employees follow mechanical rules and procedures rather than exercise judgment. In addition, as discussed earlier, the accountants on the SEC Advisory Committee notably dissented from its recommendation to exempt small firms. ${ }^{258}$

No doubt, a compelling explanation for the cautious reaction of the accounting firms is that they have adopted a decidedly risk-averse approach to

255 The three Democratic incumbents who lost all voted for the amendment, so their replacement by Republicans would not increase the number of "yes" votes. But some of the new Democrats could be expected to vote with the Democratic majority against revising SOX, if the pattern of voting in 2007 by newly-elected, swing-district Democrats is a guide to future votes on the issue. (2007).

256 See, e.g., Joseph A. Grundfest \& Steven E. Bochner, Fixing 404, 105 MiCH. L. REV. 1643

257 In comment letters, the firms persistently objected to proposed modifications to loosen audit standards, and advocated that the SEC conform its proposed definitions to more restrictive PCAOB definitions. Comments on Proposed Rule, Definition of a Significant Deficiency, 72 Fed. Reg. 35346 (June 27, 2007), available at http://www.sec.gov/comments/s7-24-06/s72406.shtml. A summary is available via the SEC's website, http://www.sec.gov/rules/proposed/2007/s72406commsumm.pdf.

258 See supra text accompanying note 39. 
liability risk in the aftermath of the Enron and other accounting scandals and resulting collapse of Arthur Andersen. Furthermore, accounting firms have also been principal financial beneficiaries of section 404, and maintenance of a lucrative revenue stream from internal control audits under the existing standard may well be an additional explanation for their resistance to the revised guidance. Of course, if a permanent small-firm exemption appeared likely to be adopted, then it is altogether possible that accounting firms might shift tactics and alter their approach to section 404 audits, in an effort to protect future revenue streams by deflecting statutory reform.

A potential wild card in the regulatory hopper for the future of SOX is the SEC staff's study of the costs and benefits of section 404, which SEC Chairman Cox requested in response to the House's appropriations bill amendment, and which has taken longer to complete than anticipated and is expected to be completed later in 2009. However, it is in the nature of staff reports to rationalize agency policies. Ambiguities in quantifying section 404's benefits, compared to its costs, should, in fact, provide ample room for the staff to support nearly any position the agency wishes to adopt with respect to small firms. ${ }^{259}$ Furthermore, unlike the Federal Reserve, whose leadership historically has been economists, or the Commodity Futures Trading Commission, which from its creation included economists at the staff and commission level, the SEC has been a lawyer-centered agency. The SEC's Office of Economic Analysis, an add-on to the original organizational structure, is an entity whose input has historically not been central in the agency's decision-making. ${ }^{260}$ The key agency decision-makers on SOX's fate,

259 It should be noted that section 404 may also impose costs that are difficult to quantify, such as increased centralization or bureaucratization of business processes besides the auditing function, or a conservative decisional bias, which may lead to a decrease in firm value. For an effort to theorize, rather than quantify, the presence of such costs, with confirming data on the perception of some such costs in a survey of executives, see Nicholas V. Vakkur, R. Preston McAfee \& Fred Kipperman, The Unintended Effects of the Sarbanes Oxley Act of 2002: A Primer for Policymakers (Feb. 17, 2009) (unpublished manuscript), available at http://ssm.com/abstract=1345475. Some researchers have found that corporate risk taking decreased post-SOX, which may be one such cost. See Leonce Bargeron, Kenneth Lehn \& Chad J. Zutter, Sarbanes-Oxley and Corporate Risk-Taking (Mar. 7, 2008) (unpublished manuscript), available at http://ssrn.com/abstract=1104063; Kate Litvak, Defensive Management: Does the Sarbanes-Oxley Act Discourage Corporate Risk-Taking? (Nov. 1, 2008) (unpublished manuscript), available at http://ssrn.com/abstract=1120971.

260 As Philip Loomis, a former Commissioner, put it:

It's been very hard for us to recruit economists or to figure out exactly how to use them in our kind of work, which doesn't involve the typical, purely economic decision. So we haven't learned how to make the best use of economists, and I think we should improve on that.

SUSAN M. PHILLIPS \& J. RiChaRd ZECHER, THE SEC AND THE PUBliC INTEREST 111 (1981) (providing Commissioner Loomis quotation in 1979 Barron's magazine).

In 1965, the agency created an Office of Policy Research headed by a Chief Economist; a description of the professional staff in the prior year's annual report made no reference to economists. SECURITIES \& EXCHANGE COMM'N, ANNUAL REPORT 156 (1964). In 1975 the SEC reorganized that office into a Directorate of Economic and Policy Research, later renamed the Directorate of Economic and Policy Analysis (DEPA), in order to "strengthen [its] capacity for economic research" and coordinate reports on institutional investors - required by legislation enacted that year-and the effort to develop a national market system. SECURITIES \& EXCHANGE COMM'N, ANNUAL REPORT 167 (1975). The Office of the Chief Economist was created in 1982, as a separate entity supplementing the DEPA's 
in other words, will not be individuals whose professional training would make them particularly attentive to ascertaining whether their regulatory theory is supported by data.

A glimpse into the likely outcome of the cost-benefit study can be ascertained from a response to written questions by Mary Schapiro on her nomination as the new SEC Chairman. Schapiro indicated that she would move ahead with implementing section 404 for small firms, although commentators characterized her response as "ducking" the issue. ${ }^{261}$ That response would suggest that there will be pressure on the staff to craft a report amenable to multiple interpretations and thereby capable of supporting a conclusion by the commissioners that SOX's costs are worth its benefits for small firms. ${ }^{262}$ The possibility that the agency could reach a conclusion in conflict with the most plausible reading of the research on the section's adverse impact on business would not come as a surprise to a student of the agency, as the commissioners have a rich history of ignoring empirical research that did not accord with their policy priors: for example, the agency adopted rules restricting auditors' provision of non-audit services despite a total absence of data that would support its position in the reports of two agency-commissioned panels. ${ }^{263}$

work with an academic economist brought in as the Chief Economist, to "draw increased attention to the fundamental economic issues raised by the agency's regulatory actions." SECURITIES \& EXCHANGE COMM'N, ANNUAL REPORT 58 (1982). This elevation of economic analysis within the agency was an initiative by then SEC Chairman John Shad who, not fortuitously in my judgment, was an investment banker and not a lawyer. Following the stock market crash in the fall of 1987, the two departments were merged into a new office, the present Office of Economic Analysis, under the leadership of the Chief Economist. E-mail from Kenneth Lehn, Former Chief Economist (1987-91), SEC, to Roberta Romano, Oscar M. Ruebhausen Professor of Law, Yale Law School (Mar. 21, 2009, 8:12 EST) (on file with author).

261 Malini Manickavasagam, Steven Marcy \& Alison Bennett, SEC Chairman Schapiro Agrees SEC Must Reconsider Key Areas Including Proxy Access, IFRS, 7 Corp. Accountability Rep. (BNA) 124 (Jan. 30, 2009). The inquiry was from Senator Carl Levin, who was not on the committee with SEC oversight jurisdiction. Id. Chairman Schapiro's response to the Senator's inquiry about whether non-accelerated filers' compliance with section 404 would be further delayed was:

Right now we have a system where some issuers are complying with 404 and others are still exempt from it. It's time that we bring uniformity to the system so that investors know what to expect from companies, while being sensitive to the needs of small businesses. I look forward to working with the small business community in making sure they have the tools they need to comply with 404 .

Response to Questions from Senator Carl Levin by Mary Schapiro, Nominee to be Chair of the Securities and Exchange Commission (Jan. 8, 2009), http://levin.senate.gov/newsroom/ supporting/2009/PSI.SchapiroResponses.012209.pdf (last visited June 9, 2009).

262 The staff is surveying firms complying with section 404 as part of the study, and the SEC website description of the study's purpose further suggests that such a finding that SOX's cost outweighs its benefit is not in the sights of the agency's agenda, as it states: "The analysis of the data collected will help inform the Commission on whether its guidance for management on how to conduct an internal control evaluation ... [has] improved implementation of the Section 404 rules by reducing costs while still preserving the rules benefits." Spotlight on SEC Survey on Costs and Benefits of Rules Implementing Section 404 of the Sarbanes Oxley Act, http://www.sec.gov/spotlight/404survey.htm (last visited Mar. 23, 2009). 
An instructive recent illustration of the dynamic in which staff reports are used by commissioners to bolster their policy preferences is the recent SEC rulemaking that sought to require increased independence of mutual fund boards. ${ }^{264}$ After the U.S. Court of Appeals for the District of Columbia Circuit rejected the rule for inappropriate rule-making procedures, the agency responded by swiftly reenacting the rule, supplying a brief staff report in support, which the court once again rejected for being proposed without following proper procedures, and in particular, for not considering the rule's costs. ${ }^{265}$ The agency then commissioned a report by the Office of Economic Analysis on the proposed rule, and the staff's obvious dilemma in seeking to satisfy the Commission's policy preferences while remaining intellectually honest is evident in the supplemental memo of the Chief Economist. The memo explained that, despite the absence of empirical support for the rule's premise that independent boards improve fund performance and reduce fees, "the lack of such evidence may be a result of the limits of standard statistical methods in identifying such a relation and is not necessarily indicative of the failure of such a relationship to exist." ${ }^{, 266}$ That observation is not itself incorrect, but it proves too much while failing to deal with the task at hand, which is for the analyst to provide his or her best judgment given the present state of knowledge.

At best, in response to the survey data compiled by the staff, the SEC may tweak further its guidance for section 404 with greater flexibility for small firms. Small firms' compliance cost is also most likely to be the focus of any congressional activity on SOX. There are several reasons for expecting smallfirm relief to be the most probable legislative recrafting of SOX in the shortterm, if any revision is to occur. As noted earlier, there is a broadly-based constituent connection between members of Congress and small firms, which are located in all districts, in contrast to the stock exchanges, and public opinion in the United States has historically been decidedly more sympathetic towards small rather than big business. ${ }^{267}$ Rolling back regulation whose cost unduly burdens small firms would resonate with the public better than less targeted reform benefiting all firms and stock exchanges. Benefiting small firms would therefore be more politically attractive, as the rollbacks could be credibly explained to constituents who might otherwise question the need for statutory amendment. ${ }^{268}$ In addition, both parties' campaign platforms expressed support for small business, although the substantive content of

264 Investment Company Govemance, 69 Fed. Reg. 46,378 (Aug. 2, 2004) (17 C.F.R. pt. 270

265 Chamber of Commerce v. SEC, 443 F. 3d 890 (D.C. Cir. 2006); Chamber of Commerce v. SEC, 412 F. 3d 133 (D.C. Cir. 2005).

266 Siobhan Hughes, SEC Hits Hurdles in Evaluating Rule-Link Deemed Weak Between Returns, Independent Board, WALL ST. J., Jan. 4, 2007, at C15.

267 LIPSET \& SCHNEIDER, supra note 173.

268 FENNO, supra note 86 , at 151 (concluding that for the vast majority of votes, legislators are not constrained by constituent preferences and can vote "as they wish," provided that they can satisfactorily explain their votes to constituents). 
neither plank referenced SOX. ${ }^{269}$ Finally, a recent study of the stability of major legislative initiatives finds that reforms are more likely to be resisted and less likely to "stick" when those adversely affected have not yet made substantial investments in order to adapt to the new regime and marginal compliance costs are high. ${ }^{270}$ Because small firms have not yet had to undertake the significant investment in compliance related to the auditor attestation component of the statute, they can be expected to continue to resist implementation and voice opposition to public officials, in contrast to already compliant large firms.

In sum, any impetus for small-firm relief is more likely to originate in Congress than the SEC, despite the agency's undertaking of a cost-benefit analysis of section 404. Congress has, in fact, been a driving force for agency consideration of the impact regulations have on small firms. ${ }^{271}$ The SEC, by contrast, has historically tended to seek to extend its regulatory jurisdiction over small firms, ${ }^{272}$ although it has, on occasion, responded to small firms' concerns for regulatory relief under external pressure. ${ }^{273}$ Of course, were the probability of enactment of regulatory relief for small firms to increase dramatically, then the SEC could act preemptively and exempt small firms from part or all of section 404 in order to avoid the sting of a legislative rebuke. The agency's decision to defer the applicability of section 404 to small firms following the House vote prohibiting implementation expenditures is illustrative of such a tactical retreat.

2692008 Democratic National Platform, supra note 236; 2008 Republican Platform, supra note 236.

270 PATASHNIK, supra note 254, at 177.

271 For example, section 603 of the Regulatory Flexibility Act, 5 U.S.C. $\S 603$ (2006), directs agencies to analyze the cost of proposed regulations on small businesses and to consider significant alternatives that would accomplish their stated objectives, while minimizing any significant adverse impact on small entities.

272 The 1964 amendments extending the federal securities laws to small firms traded in the over-the-counter market, supra note 2, were enacted at the SEC's request and, the agency had, in fact, advocated the extension several times earlier, in 1946, 1950, and 1956. JOEL SELIGMAN, THE TRANSFORMATION OF WALL STREET: A History OF THE SECURITIES AND EXCHANGE COMMISSION AND MODERN CORPORATE FINANCE 311-13 (1995).

273 The creation of the Advisory Committee was, for example, a response to two external stimuli: small firms' complaints about SOX's costs, and business groups' opposition to the SEC Chairman's reappointment because he voted with the Democratic commissioners and against the Republican commissioners in support of a variety of regulatory initiatives. Romano, supra note 15 , at $1595-96$ n.214. Consistent with its historical effort to bring small firms within its jurisdiction, the agency did not exempt small firms from SOX as the Advisory Committee recommended. Moreover, unlike some commentators, the SEC did not contend that it lacked authority to do so. Cf. supra note 72 (discussing comments suggesting that the SEC lacks the authority to exempt small firms). But it did support other recommendations of the Advisory Committee, unrelated to SOX, to ease small firms' regulatory burdens. 


\section{Market Competitiveness Concerns}

The prognosis that small-firm relief is the most probable shape that revision of SOX would take is not to say that the market competitiveness concerns raised by the reports of the Capital Markets Committee, McKinsey Study, and Chamber Commission with respect to SOX will be altogether ignored by Congress. ${ }^{274}$ The New York metropolitan area, which is most negatively affected by this issue and has been severely impacted by the financial crisis, has, after all, a senator in a key congressional leadership position.

However, the rubric of "market competitiveness" is amenable to diverse SEC initiatives. The SEC, for instance, recently abandoned the requirement that foreign firms reconcile their financial statements with U.S. accounting principles, as long as the firms are complying with international accounting standards. ${ }^{275}$ Although this action does not alleviate the costs of SOX compliance, it undoubtedly will improve U.S. stock markets' relative competitive position, as the substantial expense entailed in reconciliation has long been considered an important reason why small foreign firms do not list on U.S. exchanges. ${ }^{276}$ The SEC also held a roundtable to explore the concept of "selective mutual recognition," under which it would cede its regulatory jurisdiction to selected home country regulators of foreign firms listed on U.S. exchanges. ${ }^{277}$ Such a policy would further aid the New York stock exchanges, as it should reduce foreign firms' U.S. listing cost by eliminating duplicate oversight, such as the need to comply with the different disclosure requirements of the SEC and home regulator. Nonetheless, it is improbable that the concept of selective mutual recognition will go beyond the Cox-chaired Commission's drawing board. The new SEC Chairman expressed opposition to pursuing an even less expansive international initiative of Chairman Cox, a proposal to permit U.S. issuers to comply with international accounting standards rather than U.S. G.A.A.P. ${ }^{278}$

But even were Chairman Schapiro amenable toward promoting international recognition initiatives, it is highly questionable whether she would be able to do much on that front in the immediate future. The SEC's focus under her leadership will undoubtedly be on enforcement and expanding

274 As previously discussed, the America COMPETES Act also included a resolution, added by unanimous consent, expressing the Sense of the Senate that U.S. capital markets were losing their "competitive edge." See supra note 198.

275 See Acceptance from Foreign Private Issues of Financial Statements Prepared in Accordance with International Financial Reporting Standards Without Reconciliation to U.S. G.A.A.P., 73 Fed. Reg. 986 (Jan. 4, 2008) (to be codified at 17 C.F.R. pts. 210, 230, 239, and 249); Marcy, supra note 159 , at 1134 .

276 See, e.g., Cochrane, supra note 64.

277 Press Release, SEC, SEC Announces Roundtable Discussion Regarding Mutual Recognition (May 24, 2007), available at http://www.sec.gov/news/press/2007/2007-105.htm.

278 Manickavasagam, supra note 261; Response to Questions from Sen. Levin by Mary Schapiro, supra note 261. 
initiatives under the rubric of "investor rights," issues of greatest interest to Democrats in Congress, as these initiatives are advocated by core political allies among unions and public pension funds. ${ }^{279}$ The agency needs to deflect criticism for failing to investigate repeated tips regarding Bernard Madoff's massive Ponzi scheme over a number of years, and for presiding over the collapse of the investment banking sector, ${ }^{280}$ and revising SOX would not seem to fit well in such an agenda, compared to those initiatives.

\section{E. A Lesson of SOX: The Need for Sunset Provisions}

The saga of SOX underscores an important lesson for Congress's impending effort to overhaul comprehensively the regulation of financial institutions: It is far easier to draft legislation in times of crisis founded on good intentions that produce unintended consequences and impose substantial costs on firms, impeding economic growth, than it is to correct such legislative blunders thereafter. That is because the limited time for deliberation, often accompanied by public hysteria that is amplified by the media, makes it more probable that the causes of the crisis and consequences of decisions will not have been sufficiently understood by policymakers and legislators to be able to ascertain how best to proceed.

The difficulty of revising poorly conceived financial-market regulation, as exemplified by the FCPA and Glass-Steagall Act, underscores the value of including in legislation a sunset provision, a mechanism that forces Congress to revisit periodically and comprehensively what it has done. Such an approach is especially important for legislation drafted in a crisis environment because the subsequent review can be undertaken more soberly and with reflection. ${ }^{281}$ To facilitate that review, Congress should further commission an empirical study

279 For example, shortly after her confirmation, Schapiro announced that the agency would move rapidly on rules regarding shareholder proxy access, and she appointed a former public pension fund employee as an advisor on the issue, an item, as noted, of interest to union funds and Democratic legislators, for which she expressed support in her nomination process. Yin Wilczek, Schapiro, Carrying Through on Promises, Directs Staff To Draft Proxy Access Proposals, 7 Corp. Accountability Rep. (BNA) 307 (Mar. 13, 2009).

280 E.g., Terry Keenan, This Ponzi Scheme Is Crème de la Crème, N.Y. Post, Dec. 14, 2008, at 35; SEC: Some Watchdog!, Boston Herald, Dec. 16, 2008, at 20; Loren Steffy, SEC Short of Wisdom on Short-Selling, HoustON CHRON., July 18, 2008, Business, at 1.

281 For commentators advocating adoption of such mechanisms, see, for example, Larry Ribstein, SarbOx: The Road to Nirvana, 2004 MICH. ST. L. REV. 279, 297; and Romano, supra note 15, at 1599-1601. In the context of emergency legislation imposing substantive organizational mandates on firms, such as the SOX governance provisions, were such provisions imposed solely as defaults from which firms could opt-out, then sunsetting, which is a second-best strategy to a voluntary approach to governance, would not be necessary. That is because firms could engage in self-help, through shareholder approval, to avoid regulation whose cost is incommensurate with the benefit in such a regime. Such an approach may be more difficult to implement in legislation revamping the regulatory architecture, rendering sunsetting a necessary solution, although a voluntary approach to a regulatory regime is not impossible were the legislation to permit firms to opt-out from the regulatory regime or to select their regulator from a menu. 
of the legislation's effects, to be undertaken by an independent blue ribbon group with expertise in the area. Such a strategy would improve the quality of decision-making and of our laws.

Mandatory periodic congressional review of crisis-mode legislation may not always result in repeal of poorly thought-out statutory and regulatory provisions, and may, in fact, impose costs on doing business by decreasing the certainty of the duration of a statute or implementing rule. But armchair speculation that sunsetting financial-market regulation will adversely affect business planning would not seem to be particularly plausible, as there was no want of innovation in derivatives products, and indeed, those markets flourished under an agency subjected to a sunset provision. Even if some investments would be deterred because they would not be completed within the legislation's authorized time frame, the costs of uncertainty generated by a sunsetting provision would, given a history littered with legislative and regulatory errors, in my judgment, be more than offset by the benefit of forcing Congress to confront early on any adverse unintended consequences of its actions, after a crisis-related panic has subsided. ${ }^{282}$

\section{Conclusion}

Although SOX was enacted with near unanimity in 2002, only a few years thereafter, four high-profile commissioned reports critiqued the legislation for having adverse economic consequences for small firms and capital markets. These critiques contributed to increasing media coverage of SOX's impact. As a consequence, they gradually seeped into the political arena.

This Article investigated the reporting on the SOX critiques by national and regional newspapers and leading business journalists to gauge the political climate for revisiting SOX. Examination of the coverage of the SOX critiques yields three core findings. First, reporting on the critiques steadily increased as media references to Enron receded, although the term "Enron" has entered the vernacular and its newspaper presence still dwarfs that of the SOX critiques. Second, market competitiveness issues tend to receive greater media attention than small firms' costs, although these concerns are not necessarily mutually exclusive. This reporting pattern is consistent with three of the four commissioned reports' emphasis on market competitiveness issues. Third, and

282 The Commodity Futures Trading Commission was created as a sunset agency, which requires periodic reauthorization, and the reauthorization process has resulted in updating its jurisdiction over derivative products and markets. For example, its authority was altered over the following products in the following reauthorizations: energy products in the 1990 and 2005 reauthorizations, the Futures Trading Practices Act of 1992, Pub. L. No. 102-546, 106 Stat. 3590 (codified at 7 U.S.C. $§ 1$ (2006)), and the Food, Conservation, and Energy Act of 2008, Pub. L. No. 110-246, 122 Stat. 1651 (to be codified at 7 U.S.C. $\$ 1$ ); foreign currency products in the 2000 reauthorization, the Commodity Futures Modernization Act of 2000, Pub L. No. 106-554, 114 Stat. 2763 (codified at 7 U.S.C. § I (2006)); and futures on individual stocks in the 1980 and 2000 reauthorizations, the Futures Trading Act of 1982, Pub. L. No. 97-444, 96 Stat. 2294 (codified at 7 U.S.C. $\S 1$ (2006)) and Commodity Futures Modernization Act of 2000 , respectively. For a brief discussion of the costs and benefits of sunset legislation see Romano, supra note 15, at 1600-01. 
most intriguing from a political economy standpoint, regional newspapers and the Washington Post devoted equal attention to small-firm compliance costs and capital-market competitiveness issues and hence provided greater relative coverage of small-firm costs than did the New York-based national press.

Paralleling regional papers' and the Washington Post's greater relative emphasis on small-firm costs than that of the New York-centered national press, members of Congress have focused their attention on the burden SOX places on small firms rather than on capital markets. Most of the bills introduced to revise SOX have been directed at small firms' compliance costs, and that issue has been the subject of two congressional votes that convey legislators' sense of unease with the statute. Although nearly all of the sponsors of the legislative proposals to revise SOX have been Republicans, a provision to defer small firms' compliance with the statute's auditor attestation requirement-the focus of the critiques-passed in the Democrat-controlled House. A procedural motion to consider a proposal to exempt small firms permanently from that requirement failed in the Senate. However, the motion was supported by a decisive majority of Republicans, and the vote followed a maneuver by the Senate Banking Committee leadership to consider first a competing resolution, which was unanimously adopted, that recognized the SEC was revising its attestation guidelines to reduce compliance costs, enabling senators to express support for small-firm relief without having to vote on it.

The congressional votes on SOX are quite fascinating, as they evince that the statute's legitimacy has been put into question in the political arena and not simply in the academic literature. Two central factors bearing on the prospects for SOX's revision are the macro- political and economic environments. The bulk of support for revising SOX, as reflected in bill sponsorship and the recent votes, has come from the minority Republican party. The Democrats who have supported SOX's revision tend to be more politically vulnerable legislators with small-firm constituencies. Given the Republicans' loss of the presidency and a majority in Congress, it is improbable that SOX will be recrafted in the short term. Although the current financial crisis has shifted congressional priorities to consideration of the regulation of financial institutions, thus removing SOX from the short-term political agenda, the statute's recrafting could move up on the national policy agenda even in the absence of Republican political control, if a link could be established in the public's mind between a reduction in the burden of SOX on small firms and mechanisms to jump start a deeply troubled economy.

It is likely to take considerable time before SOX is revised, despite evidence of costs incommensurate with benefits for many firms. That fact should serve as a cautionary tale for those seeking to refashion the regulatory architecture for financial institutions in the wake of the financial crisis. The saga of SOX's section 404 makes plain the danger of the well-known perversity of unintended consequences of good intentions. Legislators would be 
well advised to include in any comprehensive regime change sunsetting provisions, along with independent program evaluations to guide the sunset review process, to minimize the potential that they will have imposed substantial costs outweighing any benefits. 
Tables

Table 1: Recommendations of Reports Commissioned To Examine SOX's Impact

\begin{tabular}{|c|c|c|}
\hline Entity Issuing Report & Date & Key Recommendations \\
\hline $\begin{array}{l}\text { SEC Advisory } \\
\text { Committee on Smaller } \\
\text { Public Companies }\end{array}$ & $4 / 2006$ & $\begin{array}{l}\text { - Establish system of scaled securities regulation for } \\
\text { smaller firms } \\
\text { - Exempt smallest firms from } \S 404 \text { unless and until } \\
\text { a separate framework is developed for small } \\
\text { companies } \\
\text { - Exempt small firms from } \S 404 \text { auditor } \\
\text { involvement unless and until a separate framework } \\
\text { is developed for small companies } \\
\text { - Clarify scope of loan prohibition to permit } \\
\text { indemnification advances, cashless option } \\
\text { exercises, split-life insurance, and relocation loans } \\
\text { - Relax private offering solicitation restrictions } \\
\text { - Adopt litigation safe-harbor protocol for } \\
\text { accountants }\end{array}$ \\
\hline $\begin{array}{l}\text { Committee on Capital } \\
\text { Markets Regulation }\end{array}$ & $11 / 2006$ & $\begin{array}{l}\text { - Modify implementation of } \& 404 \text { rather than } \\
\text { exempt small firms: Redefine materiality; increase } \\
\text { auditor guidance to reduce costs; adopt multi-year } \\
\text { rotational testing for low-risk components } \\
\text { - Exempt foreign firms with equivalent home-state } \\
\text { regulation } \\
\text { - Reduce auditor liability }\end{array}$ \\
\hline $\begin{array}{l}\text { McKinsey Study for } \\
\text { New York City Mayor } \\
\text { Bloomberg and New } \\
\text { York State Senator } \\
\text { Schumer }\end{array}$ & $1 / 2007$ & $\begin{array}{l}\text { - Clarify guidance of } \S 404 \text { implementation: } \\
\text { Redefine materiality; risk-based approach } \\
\text { - Consider exemption for foreign firms and letting } \\
\text { small firms opt out } \\
\text { - Reform securities litigation: Reduce auditor } \\
\text { liability and promote arbitration }\end{array}$ \\
\hline $\begin{array}{l}\text { Chamber of Commerce } \\
\text { Bipartisan Commission } \\
\text { on the Regulation of } \\
\text { Capital Markets in the } \\
21 \text { st Century }\end{array}$ & $3 / 2007$ & $\begin{array}{l}\text { - Incorporate SOX into } 1934 \text { Act (to clarify } \\
\text { applicability of SEC's rulemaking and exemptive } \\
\text { power to } \S 404 \text { and other SOX provisions) }\end{array}$ \\
\hline
\end{tabular}


Table 2: Newspaper Coverage of SOX

2A: National Business Journalists' Coverage of SOX, 1/1/2001-6/10/2007

\begin{tabular}{|c|c|c|c|c|c|c|c|c|c|}
\hline & 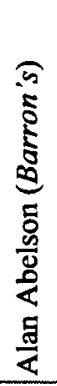 & 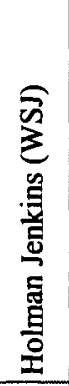 & 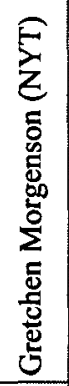 & 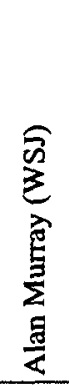 & 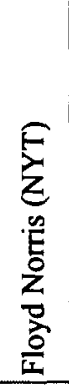 & 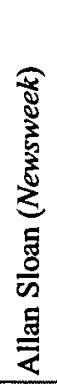 & 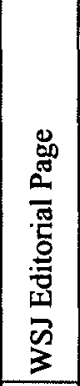 & 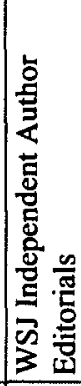 & 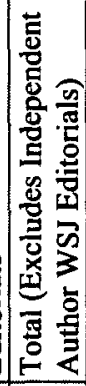 \\
\hline Advisory Committee & 0 & 0 & 0 & 0 & 8 & 0 & 0 & 2 & 8 \\
\hline Capital Markets Committee & 2 & 1 & 0 & 4 & 4 & 0 & 2 & 5 & 13 \\
\hline Chamber Commission & 0 & 0 & 0 & 0 & 0 & 0 & 0 & 3 & 0 \\
\hline McKinsey Study & 0 & 0 & 0 & 0 & 0 & 0 & 1 & 4 & 1 \\
\hline Market Competitiveness & 2 & 1 & 0 & 6 & 12 & 1 & 11 & 15 & 33 \\
\hline IPO but not Foreign-Market Listing & 1 & 0 & 0 & 0 & 0 & 0 & 0 & 0 & 1 \\
\hline Going-Private but not Foreign Firm & 1 & 0 & 0 & 2 & 0 & 1 & 3 & 2 & 7 \\
\hline Foreign-Market Competitiveness & 0 & 1 & 0 & 4 & 12 & 0 & 8 & 13 & 25 \\
\hline Small-Firm Costs & 0 & 1 & 0 & 3 & 4 & 0 & 2 & 5 & 10 \\
\hline $\begin{array}{l}\text { Advocacy Against Revising SOX or } \\
\text { Disparagement of Criticisms }\end{array}$ & 4 & 0 & 1 & 5 & 7 & 0 & 0 & 3 & 17 \\
\hline $\begin{array}{l}\text { Criticism of SOX or Advocacy of } \\
\text { Rolling Back SOX }\end{array}$ & 0 & 1 & 0 & 0 & 0 & 0 & 12 & 16 & 13 \\
\hline Total SOX & 5 & 3 & 1 & 13 & 29 & 2 & 19 & 27 & 72 \\
\hline $\begin{array}{l}\text { Need More Regulation (Written Pre- } \\
\text { enactment; Not Included in Total } \\
\text { SOX) }\end{array}$ & 3 & 0 & 0 & 6 & 1 & 4 & 0 & 0 & 14 \\
\hline $\begin{array}{l}\text { More Regulation Not Needed } \\
\text { (Written Pre-enactment; Not Included } \\
\text { in Total SOX) }\end{array}$ & 0 & 3 & 0 & 0 & 0 & 0 & 2 & 0 & 5 \\
\hline Total Surveyed & 97 & 209 & 399 & 151 & 416 & 66 & 3757 & N/A & 5095 \\
\hline
\end{tabular}


2B: Regional and National Newspapers' Coverage of SOX, 12/1/20046/10/2007

\begin{tabular}{|c|c|c|c|c|c|c|c|c|}
\hline & 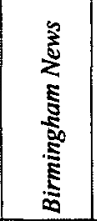 & 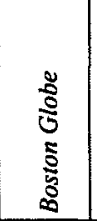 & 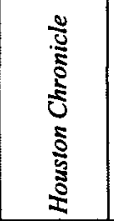 & 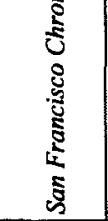 & 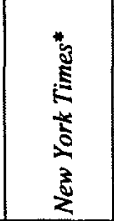 & 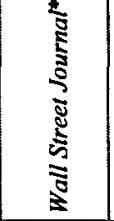 & 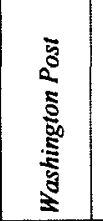 & $\stackrel{\vec{J}}{0}$ \\
\hline Advisory Committee & 1 & 4 & 3 & 9 & 3 & 26 & 12 & 58 \\
\hline Capital Markets Committee & 0 & 2 & 4 & 1 & 7 & 11 & 9 & 34 \\
\hline Chamber Commission & 0 & 0 & 1 & 0 & 2 & 4 & 5 & 12 \\
\hline McKinsey Study & 0 & 1 & 2 & 0 & 5 & 7 & 1 & 16 \\
\hline Market Competitiveness & 3 & 11 & 13 & 12 & 35 & 84 & 18 & 176 \\
\hline IPO but not Foreign-Market Listing & 0 & 3 & 1 & 4 & 2 & 10 & 1 & 21 \\
\hline Going-Private but not Foreign Firm & 0 & 1 & 4 & 3 & 3 & 15 & 7 & 33 \\
\hline Foreign-Market Competitiveness & 3 & 7 & 8 & 5 & 30 & 59 & 10 & 122 \\
\hline Small-Firm Costs & 5 & 8 & 9 & 8 & 6 & 25 & 12 & 73 \\
\hline $\begin{array}{l}\text { Advocacy Against Revising SOX or } \\
\text { Disparagement of Criticisms }\end{array}$ & 0 & 3 & 4 & 0 & 3 & 0 & 2 & 12 \\
\hline Total SOX & 16 & 29 & 51 & 31 & 73 & 166 & 93 & 459 \\
\hline Total Surveyed & 176 & 238 & 352 & 337 & 806 & 1344 & 632 & 3885 \\
\hline $\begin{array}{l}\text { All Enron References } \\
(7 / 1 / 1999-7 / 22 / 2000)\end{array}$ & 1 & 19 & 227 & 14 & 50 & 181 & 32 & 524 \\
\hline $\begin{array}{l}\text { All Enron References } \\
(7 / 1 / 2001-7 / 22 / 2002)\end{array}$ & 103 & 576 & 2098 & 621 & 2122 & 2152 & 1449 & 9121 \\
\hline $\begin{array}{l}\text { All Enron References } \\
(12 / 1 / 2004-6 / 10 / 2007)\end{array}$ & 70 & 140 & 1373 & 164 & 1106 & 977 & 756 & 4586 \\
\hline Media Slant & 0.462 & 0.424 & 0.489 & 0.403 & 0.426 & 0.485 & 0.426 & N/A \\
\hline Circulation & 145,655 & 382,503 & 503,114 & 386,564 & $1,120,420$ & $2,062,312$ & 699,130 & N/A \\
\hline Circulation Rank & 73 & 14 & 9 & 13 & 3 & 2 & 7 & N/A \\
\hline Population & 229,800 & 599,351 & $2,208,180$ & 764,976 & $8,274,527$ & $\mathrm{~N} / \mathrm{A}$ & 588,292 & N/A \\
\hline Population Rank & 81 & 23 & 4 & 14 & 1 & N/A & 27 & N/A \\
\hline
\end{tabular}


2C: Independent Author Editorials on SOX in Regional and National Newspapers, 12/1/2004-6/10/2007

\begin{tabular}{|c|c|c|c|c|c|}
\hline . & 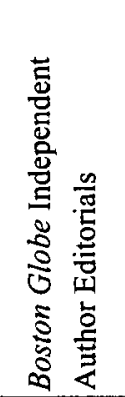 & 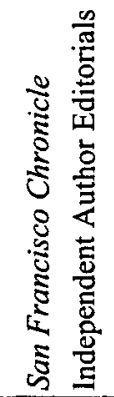 & 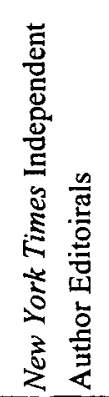 & 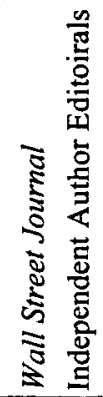 & 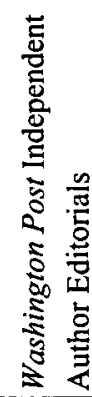 \\
\hline Advisory Committee & 0 & 0 & 0 & 2 & 0 \\
\hline Capital Markets Committee & 1 & 0 & 0 & 5 & 9 \\
\hline Chamber Commission & 0 & 0 & 0 & 3 & 0 \\
\hline McKinsey Study & 1 & 0 & 0 & 4 & 0 \\
\hline Market Competitiveness & 1 & 0 & 1 & 15 & 2 \\
\hline IPO but not Foreign-Market Listing & 0 & 0 & 0 & 0 & 0 \\
\hline Going-Private but not Foreign Firm & 0 & 0 & 0 & 2 & 0 \\
\hline Foreign-Market Competitiveness & 0 & 0 & 0 & 13 & 0 \\
\hline Small-Firm Costs & 1 & 0 & 1 & 5 & 0 \\
\hline $\begin{array}{l}\text { Advocacy Against Revising } \\
\text { SOX or Disparagement } \\
\text { of Criticisms }\end{array}$ & 1 & 0 & 0 & 3 & 0 \\
\hline $\begin{array}{l}\text { Criticism of SOX or Advocacy of } \\
\text { Rolling Back SOX }\end{array}$ & 0 & 0 & 0 & 16 & 0 \\
\hline Total SOX & 2 & 1 & 1 & 27 & 2 \\
\hline
\end{tabular}


Table 2 Notes: * Counts in Panel B of the table for the New York Times ("NYT") and Wall Street Journal ("WSJ") exclude stories tallied in Panel A of the table, by national journalists in these newspapers and the Wall Street Journal editorial page, except for the counts in the row of "Total Surveyed"; "N/A"stands for "not applicable"; "Market Competitiveness" includes references to IPOs or going private transaction numbers, whether foreign or domestic, that are separately tabulated in the following rows for domestic-only IPO and going private references; the difference, representing stories referencing foreign firms, is "Foreign-Market Competitiveness"; "Total SOX" includes articles that had some reference to costs and/or benefits of SOX, or issues involving internal controls provisions; articles referencing other SOX issues, such as accounting disclosure, accountants' conflict of interest, independent audit committees, or on the specific accounting scandal company fraud trials, are excluded; totals of all SOX-related issues articles, including the excluded topics, for the shorter period 4/1/2005$11 / 1 / 2006$, compared to articles included in "Total SOX" from that same time period are: Birmingham News 22:1, Boston Globe 15:5, Houston Chronicle 53:18, San Francisco Chronicle 17:7; "Total Surveyed" is the total number of articles produced by the Lexis searches described in the Appendix plus the number of articles added to "Total SOX" from reading hard copies of the business sections of the Birmingham News and Houston Chronicle for the entire sample period 12/1/2004-6/10/2007. Independent author editorials tabulated in Panel $C$ of the Table are not included in counts for the newspapers, except in the entry "Total Surveyed." The counts for the specified referenced topics do not add up to "Total SOX" because some articles might reference more than one topic (which are double counted) and some articles discussed costs without referencing small firms in particular. "All Enron References" are counts of all articles, including letters to the editor, referring to Enron, many of which articles have nothing to do with Enron, as discussed in the Appendix, which describes the Lexis search. For this search, only the regional newspapers' content contained in the electronic database was tracked. "Media Slant" is derived from the relative use of phrases in congressional debates by legislators of different political parties as calculated by Matthew Gentzkow \& Jesse Shapiro, supra note 120, and accompanying data pack. Data Pack Distribution Date was Monday, October 30, 2006 and is available from the NBER. "Circulation (Rank)" is the average total paid circulation (rank) for weekday (M-F) editions over the six months ended 3/31/2007, provided by the Audit Bureau of Circulations, available at http://abcas3.accessabc.com/ecirc/ newsform.asp. "Population (Rank)" is the estimated population (rank) as of $7 / 1 / 2007$, the most recent estimate, for incorporated places over 100,000 , provided by the U.S. Bureau of the Census, available at http://www.census.gov/popest/cities /SUB-EST 2007.html. 
Table 3: Time Trend in Media Coverage on SOX

\begin{tabular}{|c|c|c|c|c|c|c|}
\hline & §్ & §ิ & 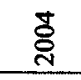 & $\stackrel{\check{\Sigma}}{8}$ & ఫั & ¿্స \\
\hline & \multicolumn{6}{|c|}{ National Business Journalists } \\
\hline Committee Reports & & & 0 & 1 & 17 & 4 \\
\hline Small-Firm Costs & 0 & 0 & 1 & 3 & 6 & 0 \\
\hline Market Competitiveness & 0 & 1 & 4 & 8 & 15 & 5 \\
\hline IPO but not Foreign-Market Listing & 0 & 0 & 0 & 0 & 0 & 1 \\
\hline Going-Private but not Foreign Firm & 0 & 1 & 1 & 2 & 1 & 2 \\
\hline Foreign-Market Competitiveness & 0 & 0 & 3 & 6 & 14 & 2 \\
\hline $\begin{array}{l}\text { Advocacy Against Revising SOX or Disparagement of } \\
\text { Criticisms }\end{array}$ & 0 & 0 & 1 & 3 & 10 & 3 \\
\hline Criticism or Advocacy of Rolling Back SOX & 2 & 1 & 1 & 4 & 5 & 0 \\
\hline \multirow[t]{2}{*}{ Total SOX } & 3 & 2 & 10 & 18 & 32 & 7 \\
\hline & \multicolumn{6}{|c|}{ Regional Newspapers } \\
\hline Committee Reports & & & 0 & 6 & 19 & 3 \\
\hline Small-Firm Costs & & & 0 & 7 & 21 & 2 \\
\hline Market Competitiveness & & & 1 & 4 & 23 & 11 \\
\hline IPO but not Foreign-Market Listing & & & 1 & 2 & 3 & 3 \\
\hline Going-Private but not Foreign Firm & & & 0 & 2 & 3 & 2 \\
\hline Foreign-Market Competitiveness & & & 0 & 0 & 17 & 6 \\
\hline $\begin{array}{l}\text { Advocacy Against Revising SOX or Disparagement of } \\
\text { Criticisms }\end{array}$ & & & 0 & 0 & 3 & 4 \\
\hline Criticism or Advocacy of Rolling Back SOX & & & 0 & 0 & 0 & 0 \\
\hline Total SOX & & & 8 & 35 & 60 & 24 \\
\hline \multirow[t]{2}{*}{ All Enron References } & 1240 & 1226 & 966 & 1782 & 936 & 156 \\
\hline & \multicolumn{6}{|c|}{ National Newspapers } \\
\hline Committee Reports & & & 3 & 16 & 50 & 23 \\
\hline Small-Firm Costs & & & 2 & 16 & 21 & 4 \\
\hline Market Competitiveness & & & 4 & 22 & 75 & 36 \\
\hline IPO but not Foreign-Market Listing & & & 0 & 4 & 7 & 2 \\
\hline Going-Private but not Foreign Firm & & & 1 & 9 & 11 & 4 \\
\hline Foreign-Market Competitiveness & & & 3 & 9 & 57 & 30 \\
\hline $\begin{array}{l}\text { Advocacy Against Revising SOX or Disparagement of } \\
\text { Criticisms }\end{array}$ & & & 0 & 1 & 1 & 3 \\
\hline Total SOX & & & 12 & 91. & 162 & 67 \\
\hline All Enron References & 1721 & 1708 & 1323 & 1103 & 1328 & 322 \\
\hline
\end{tabular}


Table 3 Notes: Data descriptions are in Table 2. The search period begins $7 / 22 / 2002$ for national business journalists and 12/1/2004 for regional and national papers for SOX stories, but the search period for Enron references was for the full years, starting with $1 / 1 / 2002$. The number of Enron references for the month of December-the SOX search period for that year-is 38 for the regional newspapers and 86 for the national newspapers.

Table 4: Salience of SOX Coverage by Location in Newspaper

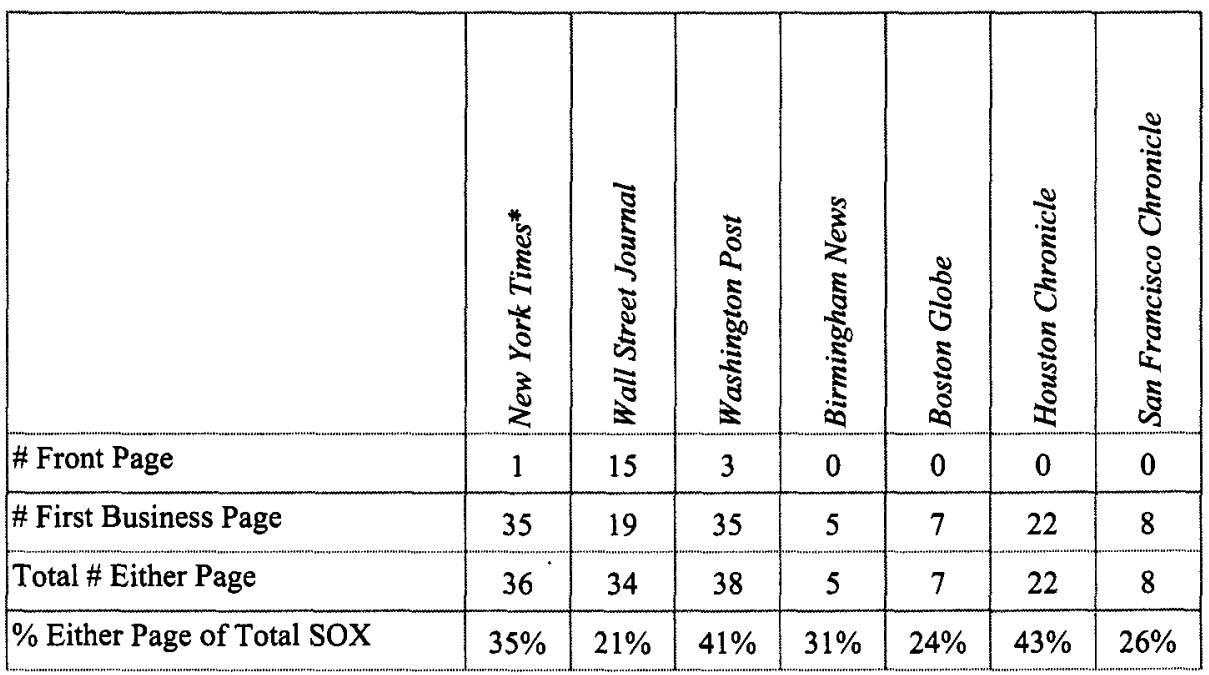

Table 4 Notes: * New York Times entries include fifteen articles on the first business page by Floyd Norris, whose articles are otherwise tallied separately as a national journalist. None of the other articles by national journalists writing for these newspapers were on front or first business pages. Data are described in Table 2. 
Table 5: Deregulatory Bills on SOX

5A: Trend of Deregulatory Bill Introductions, 2003-2007

\begin{tabular}{|l|c|c|c|}
\hline \multicolumn{1}{|c|}{ Congress } & \# Bills & \# with Republican Sponsor & $\begin{array}{c}\text { \# Cosponsors } \\
\text { (\# Republicans) }\end{array}$ \\
\hline 108 th (2003-2004) & 0 & 0 & 0 \\
\hline 109 th (2005-2006) & 7 & 7 & $146(125)$ \\
\hline 110 th (2007-) & 8 & 6 & $135(117)$ \\
\hline
\end{tabular}

5B: Detail on Bills with Provisions to Alter SOX § 404

\begin{tabular}{|c|c|c|c|c|}
\hline Bill & Short Description & $\begin{array}{c}\text { Date } \\
\text { Introduced }\end{array}$ & $\begin{array}{l}\text { Sponsor's } \\
\text { Party }\end{array}$ & $\begin{array}{l}\text { Cosponsors } \\
\text { (Republicans) }\end{array}$ \\
\hline H.R. 1641 & Make section voluntary & $4 / 14 / 2005$ & Republican & $0(0)$ \\
\hline H.R. 2061 & $\begin{array}{l}\text { Exempt community banks (in } \\
\text { community bank bill) }\end{array}$ & $5 / 3 / 2005$ & Republican & $88(69)$ \\
\hline H.R. 5405 & $\begin{array}{l}\text { Make voluntary for small firms; } \\
\text { implementation standard }\end{array}$ & $5 / 17 / 2006$ & Republican & $25(24)$ \\
\hline H.R. 6416 & Exempt certain financial institutions & $12 / 7 / 2006$ & Republican & $0(0)$ \\
\hline S. 1568 & $\begin{array}{l}\text { Exempt community banks (in } \\
\text { community bank bill) }\end{array}$ & $7 / 29 / 2005$ & Republican & $4(4)$ \\
\hline S. 2824 & $\begin{array}{l}\text { Make voluntary for small firms; } \\
\text { implementation standard }\end{array}$ & $5 / 17 / 2006$ & Republican & $10(10)$ \\
\hline H.R. 1049 & $\begin{array}{l}\text { Implementation standard; no private } \\
\text { right of action under } 404\end{array}$ & $2 / 14 / 2007$ & Republican & $20(20)$ \\
\hline H.R. 1508 & $\begin{array}{l}\text { Implementation standards, exempt } \\
\text { small firms }\end{array}$ & $3 / 13 / 2007$ & Democrat & $28(27)$ \\
\hline H.R. 1550 & Exempt certain financial institutions & $3 / 15 / 2007$ & Republican & $0(0)$ \\
\hline H.R. 1780 & $\begin{array}{l}\text { Implementation standards, special } \\
\text { rules for small firms }\end{array}$ & $3 / 30 / 2007$ & Republican & $5(4)$ \\
\hline H.R. 1869 & $\begin{array}{l}\text { Exempt community banks (in } \\
\text { community bank bill) }\end{array}$ & $4 / 17 / 2007$ & Democrat & $25(13)$ \\
\hline H.R. 2727 & $\begin{array}{l}\text { Delay implementation for small } \\
\text { firms }\end{array}$ & $6 / 14 / 2007$ & Republican & $52(48)$ \\
\hline S. 869 & $\begin{array}{l}\text { Implementation standards, exempt } \\
\text { small firms }\end{array}$ & $3 / 14 / 2007$ & Republican & $2(2)$ \\
\hline S. 1405 & $\begin{array}{l}\text { Exempt community banks (in } \\
\text { community bank bill) }\end{array}$ & $5 / 16 / 2007$ & Republican & $3(3)$ \\
\hline
\end{tabular}


Table 6: Hearings on SOX

\begin{tabular}{|l|c|c|}
\hline \multicolumn{1}{|c|}{ Congress } & \# Hearings House & \# Hearings Senate \\
\hline 108th, 1st sess. (2003) & 1 & 2 \\
\hline 108th, 2d sess. (2004) & 2 & 2 \\
\hline 109th, 1st sess. (2005) & 2 & 1 \\
\hline 109 th, 2d sess. (2006) & $7^{*}$ & 1 \\
\hline 110 th, 1st sess. (through June 2007) & $3^{*}$ & 2 \\
\hline
\end{tabular}

Table 6 Note: * Includes Appropriations Committee hearing at which member raises questions about $\mathrm{SOX}$.

Table 7: Summary Statistics: Congressional Votes

7A: Senate Vote on Motion To Table DeMint Amendment

\begin{tabular}{|c|c|c|c|c|c|}
\hline & $\begin{array}{c}\text { (1) } \\
\text { Republicans } \\
\text { against Tabling } \\
\text { DeMint } \\
\text { Amendment } \\
\end{array}$ & $\begin{array}{c}(2) \\
\text { Republicans for } \\
\text { Tabling Demint } \\
\text { Amendment }\end{array}$ & $\begin{array}{l}\text { Significance } \\
\text { of t-test for } \\
\text { difference in } \\
\text { means, cols. } \\
\text { (1) v. (2) }\end{array}$ & \begin{tabular}{|c|}
$(3)$ \\
Democrats for \\
Tabling \\
Demint \\
Amendment
\end{tabular} & \begin{tabular}{|} 
Significance of \\
t-test for \\
difference in \\
means, cols. (2) \\
v. (3)
\end{tabular} \\
\hline Number of Senators & 34 & 14 & & 47 & \\
\hline Ideology & 0.5 & 0.42 & & -0.42 & ** \\
\hline Small Bus. Comm. & 0.18 & 0.21 & & 0.17 & \\
\hline Banking Comm. & 0.18 & 0.29 & & 0.21 & \\
\hline Up for Election in 2008 & 0.44 & 0.43 & & 0.19 & * \\
\hline Years in Office & 12 & 18 & ** & 16 & \\
\hline Electoral Margin & 0.22 & 0.39 & $* *$ & 0.23 & $*$ \\
\hline Age & 63 & 67 & & 61 & \\
\hline Leadership Position & 0.12 & 0 & ** & 0.11 & \\
\hline \# Local Chambers & 53.7 & 30 & $* *$ & 56 & $* *$ \\
\hline \# Establishments & 119,526 & 48,477 & $* *$ & 143,219 & $* *$ \\
\hline Bill Cosponsorship & 0.47 & 0.07 & $* *$ & 0 & \\
\hline$\%$ Bus. PAC Contrib. & 0.82 & 0.85 & & 0.56 & $* *$ \\
\hline$\%$ Sec./Inv't Contrib. & 0.03 & 0.04 & & 0.04 & \\
\hline \$ Chamber Contrib. & $\$ 2588$ & $\$ 679$ & $* *$ & $\$ 651$ & \\
\hline Chamber Contrib. & 0.5 & 0.21 & * & 0.15 & \\
\hline
\end{tabular}


7B: House Vote on Garrett Amendment

\begin{tabular}{|c|c|c|c|c|c|}
\hline & $\begin{array}{c}\text { (1) } \\
\text { Democrats } \\
\text { Voting for the } \\
\text { Garrett } \\
\text { Amendment }\end{array}$ & $\begin{array}{c}\text { (2) } \\
\text { Democrats } \\
\text { Voting Against } \\
\text { the Garrett } \\
\text { Amendment }\end{array}$ & $\begin{array}{l}\text { Significance } \\
\text { of t-test for } \\
\text { difference in } \\
\text { means, cols. } \\
\text { (1) v. (2) }\end{array}$ & $\begin{array}{c}\text { (3) } \\
\text { Republicans } \\
\text { Voting for the } \\
\text { Garrett } \\
\text { Amendment }\end{array}$ & $\begin{array}{l}\text { Significance of } \\
\text { t-test for } \\
\text { difference in } \\
\text { means, cols. (1) } \\
\text { v. (3) }\end{array}$ \\
\hline $\begin{array}{l}\text { Number of } \\
\text { Representatives }\end{array}$ & 74 & 150 & & 193 & \\
\hline Ideology & -0.26 & -0.45 & $* *$ & 0.52 & * \\
\hline $\begin{array}{l}\text { Small Business } \\
\text { Comm. }\end{array}$ & 0.12 & 0.05 & $*$ & 0.08 & \\
\hline $\begin{array}{l}\text { Financial Sves } \\
\text { Comm. }\end{array}$ & 0.14 & 0.18 & & 0.17 & \\
\hline $\begin{array}{l}\text { First Elected 110th } \\
\text { Cong. (2006) }\end{array}$ & 0.34 & 0.11 & $* *$ & 0.06 & $*$ \\
\hline First Year Elected & 1999 & 1995 & $* *$ & 1996 & \\
\hline Electoral Margin & 0.31 & .50 & $* *$ & .25 & $*$ \\
\hline Age & 53 & 58 & ** & 55 & \\
\hline $\begin{array}{l}\text { Blue Dog } \\
\text { Coalition }\end{array}$ & 0.46 & 0.09 & $* *$ & N/A & \\
\hline $\begin{array}{l}\text { Leadership } \\
\text { Position }\end{array}$ & 0.01 & 0.09 & ** & 0.05 & \\
\hline$\%$ Urban District & 0.7 & 0.9 & ** & 0.74 & \\
\hline $\begin{array}{l}\text { Median Income } \\
\text { District }\end{array}$ & $\$ 38,605$ & $\$ 43,769$ & ** & $\$ 44,780$ & $*$ \\
\hline $\begin{array}{l}\% \text { Bus. } \\
\text { PAC Contrib. }\end{array}$ & 0.48 & 0.52 & & 0.81 & $*$ \\
\hline $\begin{array}{l}\% \text { Sec./Inv't } \\
\text { Contrib. }\end{array}$ & 0.008 & 0.004 & $* *$ & 0.005 & \\
\hline $\begin{array}{l}\text { Bus. Assoc. } \\
\text { Contrib. }\end{array}$ & 0.19 & 0.02 & $* *$ & 0.65 & $*$ \\
\hline
\end{tabular}

Table 7 Notes: ${ }^{*}$ indicates significant at less than $.10 ;{ }^{* *}$ indicates significant at less than .05; "N/A" stands for "not applicable"; data for Senate Democrats excludes one Democrat who voted against tabling the DeMint amendment and data for House Republicans excludes one Republican who voted against the Garrett amendment; also excluded from the table are data for nonvoting legislators (2 Democrats and 1 Republican in the Senate and 7 Democrats and 7 Republicans in the House), Sen. Sanders, who identifies himself as independent (but the results are identical if Sen. Sanders is included with the Democrats), and delegates and the representative for the District of Columbia (who vote under House rules but do not represent voters living in a U.S. state); "Ideology" is the legislator's DWNOMINATE score, a measure calculated by the legislator's roll call votes in the 
109th Congress, where negative scores are liberal and positive scores are conservative, as computed by Keith Poole \& Howard Rosenthal, supra note 25; "Small Bus. Comm." is a dummy variable for membership on the Senate or House committee with jurisdiction over small business; "Financial Svcs Comm." and "Banking Comm." are dummy variables for membership on the chamber's committee with jurisdiction over the SEC; "Electoral Margin" is the difference between the elected legislator and the largest-vote-getting opponent; for candidates with no opposition but where the state included blank ballots in its official results, the blanks were included in the calculation; "Blue Dog Coalition" is a dummy variable for membership in the Blue Dog Coalition, a group of conservative and moderate House Democrats (information available at the coalition's website at http :// www house .gov /ross /Blue Dogs /Member \%20Page .html); "Leadership Position" is a dummy variable for 5 Democratic and 4 Republican Senate leadership positions (information available from the U.S. Senate website at http://www.senate.gov/pagelayout/senators/a_three_sections_with_teasers/leadersh ip.htm), and for 17 Democratic and 10 Republican House leadership positions, identified by the parties on the U.S. House of Representatives' website at http://www.house.gov/house/orgs_pub_hse_ldr_www.shtml; 110th congressionl district variables, "\% Urban District" and "Median Income District," were obtained from Proximity, at http://proximityone.com/cd110rl.htm; "\# Local Chambers" is the number of chambers of commerce in a state, as identified in the WorldWide Chamber of Commerce Guide, available at: http://www.chamberfind.com/ index.asp; "\# Establishments" is the number of business establishments in the state identified in the 2003 census; "Bill Cosponsorship" is a dummy variable indicating whether a Senator either sponsored or cosponsored any deregulatory bill regarding SOX included in Table 5 in either the 109th or 110th Congresses; "\% Bus. PAC Contrib." is the proportion of PAC contributions from business; "\% Sec./Inv't Contrib." is the proportion of total funds raised that were from individuals or organizations in the securities and investment industry when that industry was one of the candidate's top 20 industry contributors; "\$ Chamber Contrib." is the dollar amount of contributions received from the U.S. Chamber of Commerce; "Chamber Contrib." is an indicator variable for whether the candidate received a campaign contribution from the U.S. Chamber of Commerce; "Bus. Assoc. Contrib." is an indicator variable for whether the candidate received a campaign contribution from the U.S. Chamber of Commerce, National Federation of Independent Associations, or a local chamber of commerce (with all contribution data from the senator's most recently completed six-year election cycle and from the 2006 election cycle for House members, as calculated by the Center for Responsive Politics, available at http://www.opensecrets.org); t-statistics are calculated using Welch's formula where the variances of the two groups are unequal; there are no differences in statistical significance whether the comparison of means was computed using Welch's formula or Satterthwaite's approximation formula for equal variances in Stata with the following exceptions: for the Senate, (1) for intra-Republican comparisons for bill sponsorship, leadership positions, and proportion of funds raised from the securities and investment industry, and for comparisons with Democrats for bill sponsorship and chamber numbers, without the Welch adjustment the difference is significant at .10; and (2) for the comparison with 
Democrats for the electoral margin, without the Welch adjustment the difference is significant at .05; for the House, for the comparison of intra-Democrats for presence on the small business committee and for the comparison with Republicans for electoral margin, without the Welch adjustment the difference is significant at less than .05 . 
Table 8: Explaining Congressional Votes

\begin{tabular}{|c|c|c|c|c|c|c|c|c|}
\hline & \multicolumn{2}{|c|}{ Senate Vote } & \multicolumn{2}{|c|}{ Senate Vote } & \multicolumn{2}{|c|}{ House Vote } & \multicolumn{2}{|c|}{ House Vote } \\
\hline & $\beta$ & se & $\beta$ & se & $\beta$ & se & $\beta$ & se \\
\hline Ideology & 4.1 & 4.9 & & & 3.98 & 2.5 & & \\
\hline $\begin{array}{l}\text { First Elected in } \\
110 \text { th Cong. }\end{array}$ & & & & & & & 1.43 & $0.67^{* *}$ \\
\hline Years in Office & 0.03 & 0.07 & -0.015 & 0.07 & -0.016 & 0.04 & -0.034 & 0.04 \\
\hline Age & -0.04 & 0.06 & -0.024 & 0.07 & -0.047 & 0.03 & -0.03 & 0.02 \\
\hline Small Bus. Comm. & -2.6 & 1.6 & -2.6 & 1.6 & 1.97 & $0.94^{* *}$ & 0.3 & 0.91 \\
\hline $\begin{array}{l}\text { Financial Svcs or } \\
\text { Banking Comm. }\end{array}$ & 0.7 & 1.4 & 0.87 & 1.4 & -1.12 & 0.72 & -1.12 & $0.55^{* *}$ \\
\hline $\begin{array}{l}\text { \% Bus. PAC } \\
\text { Contrib. }\end{array}$ & -2.0 & 7.9 & -0.36 & 7.2 & 2.58 & 1.7 & 2.52 & $1.5^{*}$ \\
\hline$\%$ Sec./Inv't Contrib. & -41.4 & 45.4 & -55.9 & 46.7 & 8.13 & 12.8 & 19.7 & 12.8 \\
\hline Electoral Margin & -0.09 & 1.9 & -0.55 & 2 & -2.38 & $1.3^{*}$ & -3.34 & 1.2 \\
\hline Leadership Position & & & & & -2.1 & $0.75^{* *}$ & -2.5 & $0.71^{* *}$ \\
\hline Blue Dog Coalition & & & & & 0.088 & 0.74 & 0.864 & 0.53 \\
\hline \% Urban District & & & & & -2.4 & 1.6 & -2.1 & $1.1^{*}$ \\
\hline $\begin{array}{l}\text { Median Income } \\
\text { District }\end{array}$ & & & & & -0.00004 & 0.00003 & -0.0001 & $0.00002^{* *}$ \\
\hline $\begin{array}{l}\text { Up for Election in } \\
2008\end{array}$ & 0.267 & 1 & -0.24 & 0.86 & & & & \\
\hline Bill Sponsorship & 1.7 & $0.81 * *$ & 1.9 & $0.82 * *$ & & & & \\
\hline \# Establishments & 0.00004 & $0.00002 * *$ & 0.0001 & $0.00002^{* *}$ & & & & \\
\hline \# Local Chambers & -0.02 & 0.05 & -0.04 & 0.05 & & & & \\
\hline Bus. Assoc. Contrib. & & & & & 2.08 & $0.73^{* *}$ & 2.4 & $0.71^{* *}$ \\
\hline \$ Chamber Contrib. & 0.001 & $0.0003^{*}$ & 0.001 & $0.0003^{*}$ & & & & \\
\hline Constant & 0.93 & 7.5 & 2.4 & & 6.38 & $2.1^{* *}$ & 4.79 & $1.7^{* *}$ \\
\hline $\begin{array}{l}\text { Number of } \\
\text { Observations }\end{array}$ & 47 & & 48 & & 181 & & 223 & \\
\hline $\begin{array}{l}\text { Log } \\
\text { Pseudolikelihood }\end{array}$ & -16 & & -16.6 & & -60.8 & & -86.7 & \\
\hline Pseudo R2 & 0.4406 & & 0.427 & & 0.4192 & & 0.3851 & \\
\hline
\end{tabular}

Table 8 Notes: The table reports logistic regressions of congressional votes related to section 404's impact on small firms, using only votes of members of the party whose votes split, Republicans in the Senate (columns 1-4) and Democrats in the House (columns 5-8). Variables are defined in Table $7 . *=$ significant at $.05 ; * *=$ significant at 10 . 
Table 9: Predicting SOX's Amendment Over Time

\begin{tabular}{|c|c|}
\hline Year (Congress) & Probability of Amendment \\
\hline $2003(108$ th) & .065217 \\
\hline $2004(108$ th) & .092907 \\
\hline $2005(109$ th) & .127487 \\
\hline $2006(109$ th) & .145794 \\
\hline $2007(110$ th $)$ & .327967 \\
\hline $2008(110$ th $)$ & .335793 \\
\hline
\end{tabular}

Table 9 Notes: The table provides the estimated probability of SOX's being substantially amended using the hazard probability model estimated in Forrest Maltzman \& Charles Shipan, supra note 116. The model includes the following explanatory variables: Divided Government at the time of enactment, Chamber Difference at the time of enactment, Divided Government in the subsequent year, Chamber Difference in the subsequent year, Public Mood, Statutory Complexity and Divisiveness, Supreme Court Attention to the statute, and an interaction term between the two Chamber Difference variables and the log of time since enactment. "Divided Government" is a dichotomous variable for whether the President is of the same party as the majority party in Congress; "Chamber Difference" measures ideological differences across chambers as a function of differences in voting support for conference reports; "Public Mood" measures whether the public favors "liberal activist" government from opinion poll scores; "Statutory Complexity" is measured by the number of pages in Lexis; "Divisiveness" is the level of support for the statute measured by the percentage yea vote in the chamber with the smaller majority coalition; and "Supreme Court Attention" is an indicator variable for whether the Court issued an opinion involving the statute over three years prior to the observation year. The Maltzman and Shipan model was estimated for 262 statutes identified by David Mayhew as major statutes and enacted over the interval 1954-2002. The estimates in the table multiply the coefficients of the Maltzman and Shipan regression by the out-ofsample variable values for SOX. 
Appendix

\section{A. Newspaper Searches}

This section of the Appendix describes the searches used to identify the coverage of SOX detailed in Tables 2 and 3. The Lexis news database was searched for stories by individual reporters and Wall Street Journal editorials, using a search including the reporter's name (with "byline" or "by") or "editorial" section, respectively; search terms "regulat! or legis!"; and date restrictions from January 1, 2001 to June 10, 2007, with the exception that the Factiva news database was used to search for Barron's and Wall Street Journal articles and Wall Street Journal editorials for the period November 1, 2006 to June 10, 2007; that search used solely the journalist's name or "editorial" as the search terms. One of seven reporters for whom the search was conducted, Carol Loomis of Fortune, was dropped from the study because none of the 20 articles identified in the search were on a SOX-related issue. To identify stories in the regional and national newspapers, the Lexis news database file for the specific newspaper was searched using the following search: (sarbane w/5 oxley) or section 404 or (conflict of interest w/5 account! or audit!) or (option! w/5 executiv!) or (small w/3 business $w / 5$ cost!) or (small w/3 company w/5 cost!) or (accounting w/3 regulation) or (accounting w/3 legislation) or (transparency w/5 financial statement!), and the date restriction from December 1, 2004 through June 10, 2007. Two additional searches were run for the regional newspapers, which were not duplicated for the national papers because they identified no new relevant stories: (small w/2 public w/2 companies); and (independent $w / 3$ director) or (independent $w / 3$ audit $w / 3$ committee) or (internal w/ 3 control). The additional articles surveyed in those searches are not included in the "Total Surveyed" entries in Table 2 to maintain comparability across the sources.

Because the regional newspapers did not systematically provide the electronic data vendors with published articles from sources other than their own staff due to intellectual property concerns, to identify any additional such stories, counts of those articles for the Boston Globe and the San Francisco Chronicle were obtained from the following searches of those newspapers' internal databases that include all published articles. For the Boston Globe, the search was: "Sarbanes-Oxley"; "small near3 business"; and "accounting near3 regulation." For the San Francisco Chronicle, the search was: (sarbane $<\mathrm{NEAR} / 5^{\prime}$ ' oxley) or section 404 or (conflict of interest $<\mathrm{NEAR} / 5$ ' (account* or audit*) ${ }^{*}$ or (option* $<\mathrm{NEAR} / 5^{\prime}$ ' executiv*) or (small $<\mathrm{NEAR} / 3^{\prime}$ ' business $<\mathrm{NEAR} / 5^{\prime}$ cost*) or (small <NEAR/3' company $<\mathrm{NEAR} / 5^{\prime}$ ' cost*) or (accounting $<\mathrm{NEAR} / 3$ ' regulation) or (accounting $<\mathrm{NEAR} / 3$ ' legislation) or (transparency $<\mathrm{NEAR} / 5$ ' financial statement*). The business sections of the Houston and Birmingham newspapers were read on microform for the entire 
sample period to identify all non-staff relevant content because the newspapers declined to undertake a search of internal databases; most of such articles in the Houston Chronicle were in fact included in the Lexis database.

The national and regional newspapers were tracked for a shorter interval than the journalists and Wall Street Journal editorials, starting with the month in which the Advisory Committee's formation was announced, December 1, 2004. The shorter period was chosen for two principal reasons: (1) it coincided with the period of greater coverage of SOX-related regulatory issues by the individual journalists, as there was virtually no discussion by journalists of those issues before 2004; and (2) as discussed in the text, the journalists did not write, pre-SOX, on the key regulatory issues that were enacted in the legislation.

In constructing the tables, I focused on the tally of articles the search identified that relate to the policy issues at the top of the contemporary agenda, the costs imposed by the internal controls certification section 404 of the statute, articles expressing support or criticism of SOX (although most of those were within that same context), and articles referring to the four reports and their commissioning organizations that criticized section 404 described in the text. As the search terms indicate, many more issues were tracked, including regulation of the accounting profession, boards of directors, and analyst conflicts of interest. The subset of articles expressing section 404 concerns referring to the reports and commissioning organizations, and expressing support or criticism of SOX constitute the 'Total SOX' tallies in the tables. The total surveyed count is the number of articles produced by the search terms described above.

As a comparative benchmark for analyzing the salience of post-SOX coverage of the reports and their critiques of the statute, Tables 2 and 3 also include the results of a search for all articles including the word "Enron" for the seven newspapers over three time frames: (1) the time frame in which the SOX stories are tracked, December 1, 2004 through June 10, 2007; (2) the period encompassing the Enron scandal, commencing a year before the enactment of SOX, July 1, 2001, through July 22, 2002, which starts shortly after the resignation of Enron's CEO Jeffrey Skilling, that occurred a few months before Enron's collapse; and (3) for comparative purposes regarding the relative coverage of Enron before and after the scandal began, over the one year period July 1, 1999 through July 22, 2000. Because the Houston Astros' home park was named after Enron, a search consisting solely of the term "Enron" included numerous extraneous sports stories. Accordingly, I used a modified Lexis search to identify the Enron articles that are tallied in the table: "enron and not enron field and not sports," and the previously noted date restrictions. The search results are an upper limit on news coverage of the Enron scandal, as many of the stories picked up in the search did not concern the company, but were on wholly unrelated matters, such as an individual being mentioned as having worked previously for Enron, or, because the name has entered the 
vernacular, a columnist or a source compared a situation-favorably or unfavorably to "Enron."

There is some overlap in the issues involving small-firm costs and market competitiveness that are separately categorized in the tables. Articles discussing the increased cost of an IPO due to SOX are classified in the market competitiveness, rather than small-firm cost, category, although most firms that would undertake an IPO are small and hence that is an adverse effect on small firms' cost of doing business. Nevertheless, I adopted that classification because the Advisory Committee report emphasized compliance costs rather than IPO costs as the SOX problem for small firms, whereas the other three reports focused on IPO costs in conjunction with the issue of U.S. stock exchanges' declining global position.

To refine the table's identification of small-firm issues, the number of articles included in the market competitiveness count that referred to IPO issues but did not refer to foreign listings is separately indicated in the tables. The number of articles that referred to domestic firms going private but not to foreign firms is also separately indicated in the tables. These entries are in the rows immediately below the entries containing the full count of articles on market competitiveness. In addition, the entries in the tables in the rows labeled "Foreign-Market Competitiveness" are the tallies of market competitiveness stories that referred to foreign listings (that is, the difference between the full count entries and the two subsetted entries of domestic-only market competitiveness stories). These breakouts indicate that the vast majority of articles in the market competitiveness category in national newspapers had a foreign-market element, and therefore were indeed covering stock-exchange issues regarding competitiveness, rather than small firms' concerns over SOX's costs. This is less dramatically true for the regional papers, where a larger proportion of the competitiveness articles had a solely domestic firm focus. This pattern further bolsters the contention in the text that regional papers placed greater emphasis on small-firm issues than the national press. All of the crosstabulation tests for differences in reporting across the newspapers reported in the text are run both including and excluding the domestic-only IPO and going-private stories in the market competitiveness counts.

\section{B. Newspaper Article Reference Counts}

The text and tables tally references to specific topics (for example, SOX critiques and committee reports), and thereby double count articles that reference more than one topic. This approach follows the definition of salience as conspicuousness, which is measured by "frequency counts of an issue's 
appearance," as that is the approach emphasized in the media literature on agenda-setting. ${ }^{283}$

Appendix Table 1 reproduces Table 2 tallying solely articles devoted to a single referenced topic for the counts, and Appendix Table 2 summarizes the types of overlap by newspaper source. Most of the overlaps (87\%) are between a SOX critique or critiques and one or more of the reporting committees. This is because articles discussing committee reports often provided both the recommendation and the underlying rationale. Of twelve overlaps containing both critiques, four also overlapped with committee references. The smallest subset of overlaps (3\%) consists of multiple committee report references. There are somewhat more (1.2 times) overlaps referencing market competitiveness than small-firm costs. There are, of course, many more articles exclusively referencing the market competitiveness critique as well. One explanation for the higher rate of overlap with market competitiveness critiques is that there is a higher number of probable permutations for it because only one of the four committees focused on small-firm costs (there are a few overlaps between market competitiveness critiques and Advisory committee references as well as between small-firm cost critiques and the other reports, but the numbers are much lower for these overlaps than for overlaps between critiques that match the reports' foci). As a proportion of total references to a critique, the overlap referencing small firm costs is double that for market competitiveness critiques ( $57 \%$ versus $26 \%$ ). The pattern is similar across the three different types of media sources.

\section{Regional Newspapers' Use of Wire Services}

Over a majority (62\%) of the regional newspapers' coverage of the SOX critiques and reports consists of articles pulled from wire services and other newspapers. The range is from 54\% (Boston Globe) to $89 \%$ (Birmingham News). This proportion is most likely somewhat higher than the percentage of wire stories in a newspaper's total content. ${ }^{284}$ The proportion also varies by topic: for all newspapers, the proportion of wire stories on small-firm costs is higher than the proportion for market competitiveness stories; but if only foreign-referencing market competitiveness stories are examined, then the relation reverses for two newspapers, and the proportion of small-firm cost wire stories is lower (Boston Globe and Birmingham News).

To examine more closely the relation between the publication of stories across the newspapers and wire services, the same search as run for the newspapers was run in the Lexis Associated Press (“AP") database. Appendix Table 3 provides a comparison of the regional newspapers' wire service

283 Young Min, Salma I. Ghanem \& Dixie Evatt, Using a Split-Ballot Survey To Explore the Robustness of the 'MP' Question in Agenda-Setting Research: A Methodological Study, 19 INT'L J. PUB. OPINION RES. 221, 223 (2007).

284 For example, according to the head librarian of the San Francisco Chronicle, about onethird of the paper's content is pulled from other sources. 
selections to that of the AP, as a benchmark of wire coverage, along with Appendix Table 4 that compares AP coverage with that of the national newspapers. The AP and national newspapers' coverage of the different critiques appears indistinguishable: a crosstabulation of the type of critique (small firm or market competitiveness) published by the national newspapers and AP is insignificant (chi square of 1.0 for all market competitiveness articles, and .24 for foreign-only competitiveness articles).

The regional newspapers did not, however, select articles uniformly from the AP service. They selected a higher ratio of small-firm cost stories to market competitiveness stories, compared to those stories' representation on the wire service. In addition, the crosstabulations of the type of critique comparing AP to regional-selected wire stories (using all regional-selected external sources or AP sources only) are significant, with respective chi squares of 6.85 (significant at .009) and 12.0 (significant at .001), respectively, for all market competitiveness articles and 6.1 (significant at .014) and 9.0 (significant at .003 ), for foreign-only competitiveness articles. ${ }^{285}$ The crosstabulations of AP and regional staff stories are insignificant. Thus, regional newspaper editors appear to have used external sources, rather than in-house staff, to obtain the stories they considered of interest to their readers, suggesting, perhaps, that local reporters' take on SOX replicated that of the national press. The selective pattern of wire service stories is the source of the regional newspapers' greater relative attention to small firm cost over market competitiveness issues compared to national newspapers.

All of the AP stories were published in regional newspapers after they ran on the wire service, with the vast majority being published one day after the story's initial appearance. ${ }^{286}$ Appendix Table 5 tabulates the timing of these publications (for the subset of AP-selected stories referencing either a SOX critique or report) in relation to their first appearance on the wire. As the table indicates, when national newspapers reported the same story, the date varied between the day the story ran on the wire and the day a regional newspaper

285 The regional newspapers also appear to have differentially selected articles across external sources. Crosstabulating by type of critique and by type of external source (AP or non- AP sources), the difference is significant using all market competitiveness articles (chi square of 4.8, significant at .03) and marginally significant using foreign only competitiveness articles (chi square of 2.9 , significant at .09 ), compared to small-firm cost articles. There were even more small-firm cost stories selected from the AP than non-AP sources (despite its greater publication of stories on the competitiveness issue). It is possible that the distribution of articles differs across external sources, with non-AP sources printing more small-firm cost stories than the AP, but if that were the case it would magnify the apparent nonrandom selection of articles from the AP. If the non-AP sources reported on market competitiveness stories at a higher proportion of SOX coverage than did the AP, then the direction of the regional papers' selectivity of SOX stories (in favor of small-firm costs) would be the same across all of the external sources.

286 Of the AP-selected stories that referenced either SOX critiques or reports, eighteen of twenty-two were published the following day. This counts as a 'two-day after' story an article published in the San Francisco Chronicle on December 26, 2006, which ran on the AP wire on both December 24 and December 25, 2006. 
published the story. Still, over one-third of the stories that regional newspapers pulled from the wire were neither previously nor simultaneously picked up by a national newspaper. These data support the contention in the text that the editorial choices of national newspapers did not influence regional newspapers' editors' selections from the wires.

\section{Temporal Pattern of Reporting}

As indicated in the text, no systematic relation exists between the reporting by the national press (journalists or newspapers) and that of the regional newspapers. The supporting analysis of the data follows.

National Journalists. Lining up news stories chronologically, there is no diffusion pattern going from the journalists to the regionals. Only two articles published in a regional newspaper followed an article by a national journalist on the same general topic (small-firm cost, market competitiveness, etc.) within five days. Moreover, even in those cases the content was entirely different. In one case, the regional newspaper story criticized the McKinsey Study's contention that SOX was adversely affecting U.S. capital, while the national journalist's column (a Wall Street Journal editorial) published two days earlier criticized SOX and noted the irony of Senator Schumer's position on SOX in conjunction with his support of the McKinsey Study. The other case was a regional newspaper article reporting on the Advisory Committee's recommendations, whereas the national journalist column written two days earlier discussed a congressional study on small firms' being burdened by SOX and noted that the Advisory Committee would release its recommendations soon. In addition, there was a same-day overlap of publication topic in only two instances. Finally, the regional newspapers' reporting on SOX critiques continued apace in the first half of 2007, whereas that of most national journalists has not: coverage of the SOX critiques in the first half of 2007 is $15 \%$ of the national journalists' total SOX stories (where the count begins as of December 1,2004), compared to $23 \%$ of the regional newspapers' totals.

National Newspapers. Appendix Table 6 summarizes the timing of regional newspapers' coverage of SOX in relation to that of the national newspapers. The table resolves ambiguity in favor of classifying regional articles as following national reporting: regional newspaper articles in the same critique category (for example, small-firm costs, market competitiveness) are classified as following a national newspaper article even though the content of the articles is completely different. For example, a regional newspaper's story on U.S. firms going public in London, published two days after a national newspaper's story discussing critiques of the Capital Market Committee's finding that SOX contributed to a decline in U.S. markets' competitiveness, is classified as a regional story following a national story, rather than as one with no temporal relation. To provide a sense of the extent of such potential misclassification, Panel B of the table excludes such stories. The difference 
between Panels A and B, taking account of misclassification, is substantial (for example, seven of eleven market competitiveness stories are excluded).

The table further distinguishes the regional stories by whether they were authored by in-house staff or obtained from a wire service or other newspapers. The table uses the regional newspapers' publication dates for all the syndicated stories because I was only able to obtain the actual publication dates for the AP stories. On a few occasions, an article is not identified as originating from a wire service but the reporter in the byline is affiliated with a wire service and had published the same or similar story on the wire; such articles are included in the wire, and not the staff tallies in the table. The key finding here is that, of the market competitiveness stories, a smaller percentage and number of wire stories are published shortly after-that is, two, three, four, and cumulated over one to four days after - a national newspaper story than are the internal articles, but a larger number and percentage of the wire compared to internal articles are in the same one-day after interval, and the wire stories, it should be recalled, are typically reprinted a day after they appeared on the wire.

In addition to this visual check for diffusion, logistic regressions were estimated to examine the relation between the publication dates of regional and national newspaper articles for each of the two critiques (small-firm costs and market competitiveness). The dependent variable is an indicator variable for an article in any of the four regional newspapers and the explanatory variables are lagged variables for the regional and national newspaper articles over the 913day sample period, from December 1, 2004 to June 10, 2007. In the market competitiveness regressions, first order (one-day), and depending on the number of lags included, second order (two-day) lagged national article variables are significant. In the small-firm cost regressions, only the first order lagged national article variable is significant. For both types of articles, likelihood ratio tests indicated that the national, and not the regional, lags were significant. A reverse model of influence was also estimated, in which the dependent variable was an indicator variable for national newspaper articles, and for both types of critiques, the lagged regional article variables were insignificant.

The finding that national newspaper lagged indicator variables are significant suggests that national newspapers are playing an agenda-setting role, as their stories precede regional stories on a given topic. However, the statistical analysis is complicated by the regional newspapers' use of wire service stories, which creates a built-in lag because those stories are published after appearing on the wire. Because much of the reporting of the SOX critiques relates to unfolding news events, such as the release of a commissioned report, regional newspapers' greater reliance on wire services automatically makes them take longer to report on a specific event compared to a national newspaper, independent of the national newspapers' coverage. That renders the observed correlation suspect (that is, it may be a spurious finding and not evidence of intermedia influence). To investigate that further, the 
regressions were rerun for only in-house staff articles. In those regressions excluding the wire service stories, the lagged national newspaper article indicator variables are no longer statistically significantly related to the regional newspapers' coverage.

\section{E. National Press Coverage of the Committee Reports}

Most of the articles on the Advisory Committee were short or contained only passing references to the Committee, describing its formation or recommendations. On a few occasions, however, articles by Floyd Norris and the Washington Post advanced an opinion on the Committee and its work product. The common strategy in such instances was to question the Committee's composition, and hence its credibility. ${ }^{287}$ Those articles were highly one-sided, quoting principally, or solely, critics of the Committee and not providing the Committee's justification for its recommendations.

One might ask why journalists would criticize the Advisory Committee for consisting largely of individuals with small business experience when the very point of the SEC's establishing the committee was to obtain input from individuals with exactly that experience and expertise. To be sure, that objection to the Committee's composition was raised by critics of the Committee's recommendations, including former government officials whom the journalists interviewed. But why would journalists consider the objection to be a compelling one? One plausible explanation of the tactic comes from a leading media textbook, which emphasizes that "credibility is the most important thing a communicator has.",288 By questioning the membership of what would otherwise be deemed a "blue ribbon" committee, critics of the Committee's recommendations could undermine the credibility of its work product without ever having to address the merits of its recommendations. The effectiveness of such a tactic is a consideration with which prominent journalists, as well as the individuals whom they were referencing, would be thoroughly familiar.

The Wall Street Journal's coverage, by contrast, did not question the Advisory Committee's composition, nor did it take explicit positions on the

287 For instance, in his article expressing an opinion on the Committee, Norris' approach was brief and dismissive: "one of the less well-conceived actions by William $\mathrm{H}$. Donaldson... was to appoint an advisory committee on smaller public companies, stocked in significant part with people who profited from selling such shares to the public.... The commission needs to consign this report to a basement file cabinet." Floyd Norris, Why Not Let Companies Ignore a Law?, N.Y. TIMES, Mar. 10, 2006, at C1. Similarly, both a squib item and an article in the Washington Post described the Committee as "stacked" and "dominated" by small business executives, respectively. The squib contained one assessment of the recommendation, a critic's caustic comment that if firms were so concerned about costs they should reduce executive compensation. News Summary: An About Face in France, WaSH. POST, Apr. 16, 2006, at F02. The 755-word article devoted one sentence to note small firms found "new legal requirements too burdensome and expensive," and the bulk of space was devoted to discussing the views of critics of the Committee's recommendations. Kathleen Day, Small Firms Still Want SEC To Give Them a Pass, WASH. POST, Apr. 13, 2006, at D01.

288 SEVERIN \& TANKARD, supra note 123 at 139. 
Committee's recommendations. The coverage tended to provide either commentary from both supporters and critics of the Committee's recommendations, or solely the Committee's reasoning. ${ }^{289}$ The difference in approach across national papers would appear to be informed by differing perspectives: the Wall Street Journal, which had less strident and less onesided coverage, has a business focus. It is also the most conservative of the national newspapers on the media slant measure. But the most plausible explanation for its different reporting strategy is that its readers would consider it entirely appropriate for a committee examining small-firm issues to consist of individuals with substantial experience in owning and operating such businesses, and would wish to have a thorough analysis from all sides on the substantive merits of the issue. As James Hamilton emphasizes, seemingly ideological differences in news content across media outlets is typically best explained by differences in their audience. ${ }^{290}$ Underscoring the distinctive business orientation of its subscribers is the Wall Street Journal's far greater

289 In only one of its articles did the Wall Street Journal provide greater coverage to critics of the Advisory Committee. In addition, its editorials did not reference the Committee. While no Wall Street Journal journalist or editor expressed an opinion on the Committee, it did publish an article by an individual with no newspaper affiliation approving the SEC's rejection of the Committee's proposal to exempt small firms. The articles in the San Francisco Chronicle similarly never referred to the Committee's composition and were more balanced, in that, the subset of articles referencing critics of the proposal also recited business' concerns about costs. The reporting of the New York Times appears more limited than the other national newspapers, but if the articles penned by Floyd Norris were not separated out, its count would be about the same as that of the Washington Post.

Of the three New York Times articles referencing the Committee not written by Norris, one expressed a judgment concerning its report. That article, following a strategy at first glance similar to that of the articles expressing opinions on the Committee by Norris and the Washington Post, questioned the integrity of one of the Committee's co-chairs. It reported that the individual was on the board, and at one time on the audit committee, of a public company that had accounting problems, the implication being that his ethics were questionable and that the Advisory Committee was not serious about addressing accounting fraud. Stephen Labaton, Panel To Propose Exceptions to Governance Rules, N.Y. Times, Apr. 18, 2006, at $\mathrm{Cl}$. The Committee co-chair was quoted in the article as stating that the firm had not engaged in intentional wrongdoing, its stock price had not dropped nor had it been sued, and that he had been vetted by the SEC when appointed. Indeed, there was nothing in the article to suggest that there was even the appearance of impropriety in the co-chair's conduct. It is difficult to fathom why this non-news event was thought to be worthy of print in the first place, except as a calculated attempt to damage the individual's reputation and, by extension, to undermine the Committee's credibility. It is noteworthy that the journalist in question covers legal and regulatory matters for the New York Times's Washington bureau, rather than the financial beat, and that his father is a prominent plaintiffs' securities litigation lawyer. A financial journalist would run the risk of losing access to sources for future articles by writing what would be viewed by many as a malicious story. See, e.g., VINSON, supra note 114, at 138-39 (examples of local news media not covering gaffes or other negative incidents involving local legislators on whom reporters rely for information compared to nonlocal media that did not use the legislator as a source). By contrast, the criticism of the Committee's composition by Norris and the Washington Post reporters, though unbalanced, did not question any individual Committee member's character. Rather it raised a generic process concern that echoed an objection of the report's critics, including former government officials.

290 HAMILTON, supra note 21. 
coverage, compared to the other newspapers, of every SOX-related topic in Table $3 .^{291}$

A similar pattern appears in the reporting on the Capital Markets Committee. Articles in the New York Times tended not to provide arguments on both sides of the issue when discussing the Capital Market Committee's recommendations, compared to those in the Wall Street Journal, which were again more balanced. ${ }^{292}$ In addition, New York Times reporters criticized the composition of the Capital Markets Committee for including business executives and excluding former government officials or shareholder group representatives, which mirrored objections expressed by the critics of the Committee whom the journalists consulted. ${ }^{293}$

The Washington Post, as noted in the text, paid more attention than the other national newspapers to the reports, no doubt because the official status of the Advisory Committee and the close connection between the Capital Markets Committee and prominent government officials made them important objects of interest for its audience. Even more interesting is the fact that the Washington Post also provided the most in-depth coverage of the Chamber Commission Report. It was released at an event in the Capitol at which key political actors-Congressman Frank, Senator Dodd, and Chairman Coxwere present. Their presence at that event and the possibility of gleaning from their remarks what action they might take on SOX undoubtedly explain the Washington Post's interest in the Chamber Commission Report. By contrast, consistent with its Washington, and not New York-based, focus, it published only one article on the McKinsey Study, which was the subject of several articles in the New York Times and Wall Street Journal.

All of the national journalists covered the Capital Markets Committee report and ignored the other two committee reports that also centered on market

291 This pattern is consistent with the opposite level of relative coverage on social issues: a study of media reporting on drugs found the Wall Street Journal's coverage was far lower than that of other national media, including the New York Times and Washington Post. Lucig H. Danielian \& Stephen D. Reese, A Closer Look at Intermedia Influences on Agenda Setting: The Cocaine Issue of 1986, in Communication Campaigns About Drugs 47, 51 (Pamela J. Shoemaker ed., 1989) (explaining the fact that the Wall Street Journal's coverage was the least correlated with other newspapers because its "focus on business news ... lessened the newsworthiness of cocaine-related stories").

292 Of three New York Times articles that quoted critics of the recommendations, one quoted only critics and one devoted more space to critics; only one devoted equal space to critics and committee members. By contrast, of the three Wall Street Journal articles that quoted critics, two quoted equally from both sides and only one was focused on critics-an article reporting on an academic study that disputed the Capital Markets Committee's finding of a decline in the premium of cross-listed stocks that was one of the data points forming the basis for the Committee's conclusion that SOX had adversely affected market competitiveness. The Committee and its finding were only mentioned in passing. None of the New York Times articles on the McKinsey Study, however, quoted critics, despite the similarity of its criticisms and recommendations regarding SOX to those of the Capital Markets Committee.

293 As with their coverage of the Advisory Committee, the regional newspapers did not voice objections to the Capital Market Committee's composition. Indeed, the Boston Globe noted that the Committee "lean[ed] towards Wall Street" but had "reasonable balance" and individuals with "serious credentials." Steven Syre, Market Cops Taking Heat, BosTON GlOBE, Nov. 30, 2006, at D1. 
competitiveness concerns. A few plausible explanations can be advanced for this selectivity. There was a perception that the Capital Markets Committee's proposals might be placed on the political agenda, given its endorsement by the Treasury Secretary. By contrast, the McKinsey Study originated in the New York Mayor's office, and national journalists could have concluded that the study was not likely to move onto the national agenda, even though the Mayor's co-endorsee, Senator Schumer, has an important Senate leadership position. A similar conclusion could have been reached regarding the Chamber Commission report, as that Commission did not receive the imprimatur on its formation from a government official, as did the Capital Markets Committee. In addition, given the considerable overlap between the three reports, the McKinsey Study and Chamber Commission reports might not have been considered sufficiently "new" to generate additional coverage beyond that accorded to the Capital Markets Committee's report. Finally, an additional, not mutually exclusive, explanation for the absence of national journalist coverage of the Chamber Commission report could be a perception of the Chamber of Commerce as an interest group whose policy recommendations are lacking in objectivity and therefore not credible. ${ }^{294}$

294 SEVERIN \& TANKARD, supra note 123, at 158. Consistent with the conjecture that the Chamber's credibility was a source of the journalists' inattention, Gretchen Morgenson had written an article criticizing the Chamber of Commerce as being anti-shareholder because among other activity, it had successfully lobbied Congress to restrict class action litigation and successfully pursued a court challenge to the SEC's regulation of mutual funds. Gretchen Morgenson \& Glen Justice, Taking Care of Business His Way, N.Y. Times, Feb. 20, 2005, $\S 3$, at 1 . A portion of that article was devoted to questioning the integrity of the Chamber's president. The article did not provide any evidence that there was anything amiss with the transactions in question, but it fit a story line. By implying that there might be misconduct somewhere, it appears the authors intended to spark an investigation of the individual. It should be noted that the reporter and her editors have been sharply criticized by another journalist, Holman Jenkins of the Wall Street Journal, for adhering to questionable journalistic standards when they published similar stories. Holman W. Jenkins, Jr., The Times and Reality, WALL ST. J., Nov. 15, 2006, at A19. Jenkins criticized a Morgensen story for not revealing key contextual facts, contending that those facts were omitted because they would alter the understanding of a quote that otherwise fit the reporter's story line. He also criticized a front-page story by the same reporter that alleged a prominent executive had engaged in insider trading despite an acknowledgment that there was no supporting evidence for the allegation besides a whistleblowing charge by an SEC attorney, who Jenkins mentioned was of questionable credibility. The New York Times editor, in a dismissive response to the Jenkins' piece, would appear to encourage reporting that suggests possible wrongdoing, which could devastate an innocent individual's reputation, without providing corroboration. Bill Keller, Misrepresented, Insulted and Belittled, WALL. ST. J., Nov. 22, 2006, at A15.

It should be noted that only one regional newspaper reported on the Chamber Commission, and the Boston Globe, which published two stories on a study by the Greater Boston Chamber of Commerce that focused on SOX's disproportionate impact on small firms, did not report on the national Chamber's report. This suggests a different rationale for the failure of regional newspapers to cover the Chamber Commission than the one offered for the national journalists-an indifference toward the report's subject matter, SOX's impact on market competitiveness, rather than a potential credibility concern regarding the report's author. 
Appendix Tables

Appendix Table 1: Non-Overlapping Coverage of SOX

1A: National Journalists' Non-Overlapping Coverage of SOX, 1/1/2001$6 / 10 / 2007$

\begin{tabular}{|c|c|c|c|c|c|c|c|c|}
\hline & $\begin{array}{l}0 \\
\frac{0}{0} \\
8 \\
8\end{array}$ & 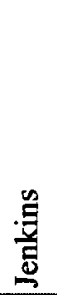 & 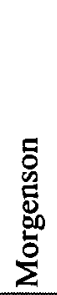 & $\stackrel{\vec{E}}{\sum_{\Sigma}^{E}}$ & $\stackrel{n}{E}$ & $\frac{\Xi}{\mathscr{D}}$ & 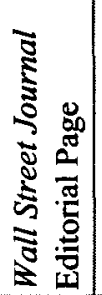 & $\stackrel{\pi}{0}$ \\
\hline Advisory Committee & 0 & 0 & 0 & 0 & 3 & 0 & 0 & 3 \\
\hline Capital Markets Comm. & 1 & 0 & 0 & 1 & 1 & 0 & 0 & 3 \\
\hline Chamber Comm'n & 0 & 0 & 0 & 0 & 0 & 0 & 0 & 0 \\
\hline McKinsey Study & 0 & 0 & 0 & 0 & 0 & 0 & 0 & 0 \\
\hline Market Competitiveness & 1 & 0 & 0 & 2 & 7 & 1 & 7 & 18 \\
\hline $\begin{array}{l}\text { Foreign-Market } \\
\text { Competitiveness }\end{array}$ & 0 & 0 & 0 & 0 & 7 & 0 & 4 & 11 \\
\hline Small-Firm Costs & 0 & 1 & 0 & 1 & 1 & 0 & 0 & 3 \\
\hline
\end{tabular}

1B: Regional and National Newspapers' Non-Overlapping Coverage of SOX, $12 / 1 / 2004-6 / 10 / 2007$

\begin{tabular}{|c|c|c|c|c|c|c|c|c|}
\hline & 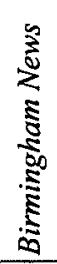 & $\begin{array}{l}8 \\
0 \\
5 \\
5 \\
5 \\
5 \\
0 \\
0\end{array}$ & 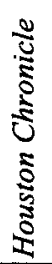 & 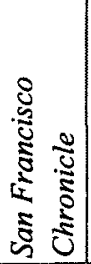 & 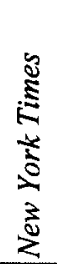 & 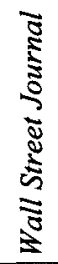 & 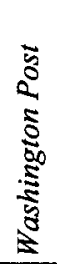 & $\underset{\tilde{0}}{\overline{0}}$ \\
\hline Advisory Committee & 0 & 0 & 2 & 3 & 2 & 11 & 7 & 25 \\
\hline Capital Markets Comm. & 0 & 0 & 0 & 1 & 3 & 1 & 5 & 10 \\
\hline Chamber Comm'n & 0 & 0 & 0 & 0 & 0 & 2 & 1 & 3 \\
\hline McKinsey Study & 0 & 0 & 0 & 0 & 0 & 0 & 0 & 0 \\
\hline Market Competitiveness & 3 & 7 & 9 & 9 & 27 & 70 & 12 & 137 \\
\hline $\begin{array}{l}\text { Foreign-Market } \\
\text { Competitiveness }\end{array}$ & 3 & 3 & 4 & 3 & 22 & 47 & 5 & 87 \\
\hline Small-Firm costs & 4 & 2 & 6 & 1 & 5 & 9 & 6 & 33 \\
\hline
\end{tabular}


1C: Independent Author Editorials' Non-Overlapping Coverage of SOX, $12 / 1 / 2004-6 / 10 / 2007$

\begin{tabular}{|c|c|c|c|c|c|}
\hline & 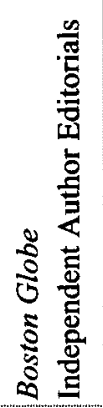 & 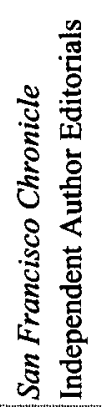 & 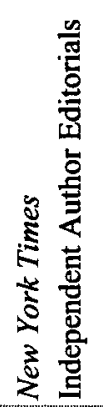 & 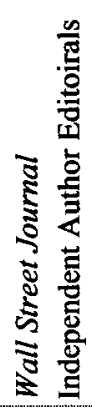 & 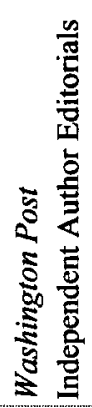 \\
\hline Advisory Committee & 0 & 0 & 0 & 0 & 0 \\
\hline Capital Markets Comm. & 0 & 0 & 0 & 0 & 0 \\
\hline Chamber Comm'n & 0 & 0 & 0 & 0 & 0 \\
\hline McKinsey Study & 0 & 0 & 0 & 1 & 0 \\
\hline Market Competitiveness & 0 & 0 & 0 & 7 & 2 \\
\hline Foreign-Market Competitiveness & 0 & 0 & 0 & 7 & 2 \\
\hline Small-Firm Costs & 1 & 0 & 0 & 2 & 0 \\
\hline
\end{tabular}

Appendix Table 1 Notes: This Table reproduces Table 2 tabulating only articles devoted to a single referenced topic ("non-overlapping" articles); see Table 2 for a description of the data. 
Appendix Table 2: Overlapping Coverage of SOX by Content

2A: National Journalists' and National and Regional Newspapers' Overlapping Coverage of SOX by Content

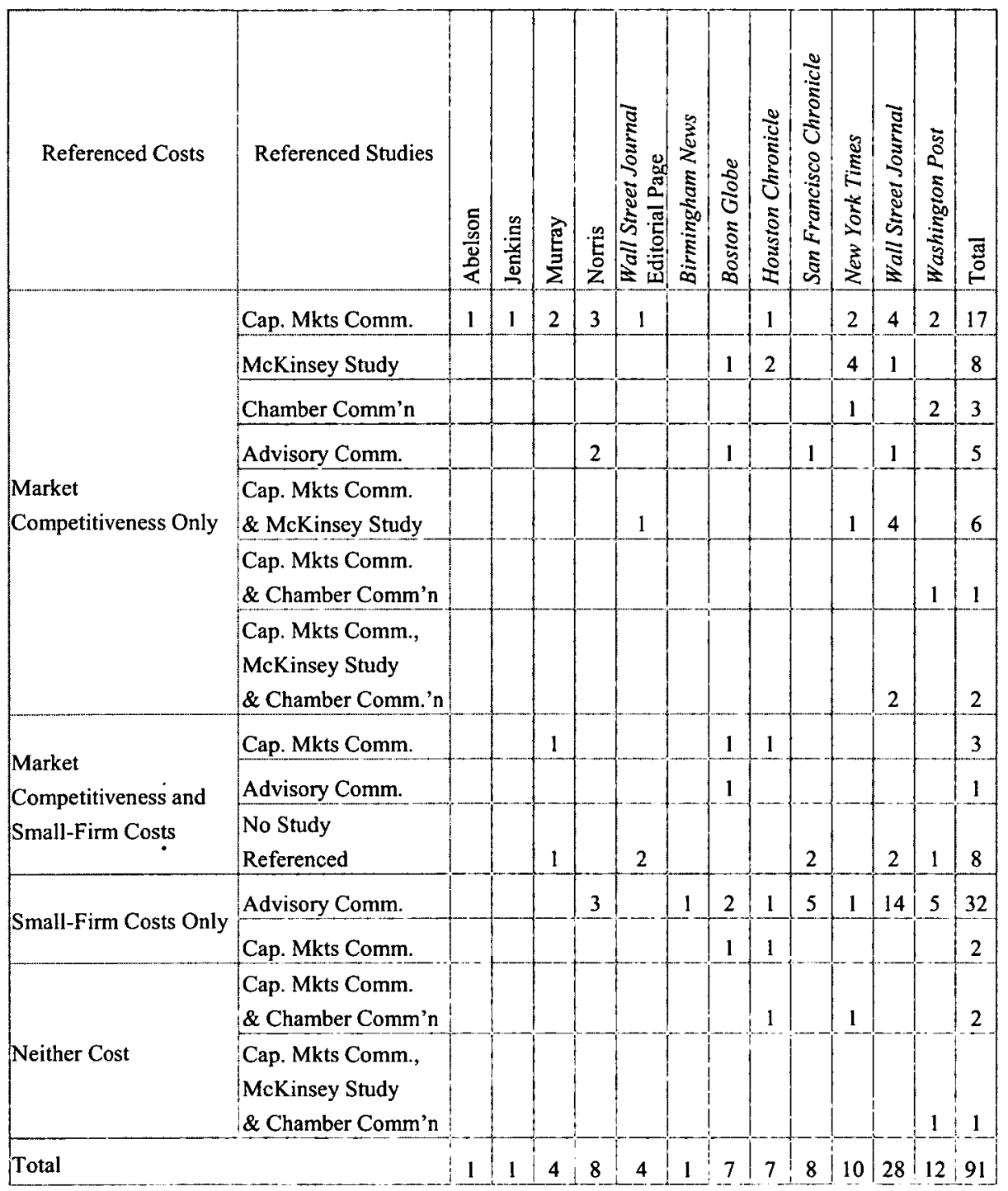


2B: Independent Author Editorials' Overlapping Coverage of SOX by Content

\begin{tabular}{|c|c|c|c|c|c|}
\hline Referenced Costs & Referenced Studies & 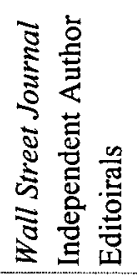 & 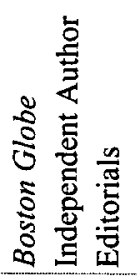 & 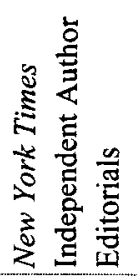 & 흄 \\
\hline \multirow{4}{*}{$\begin{array}{l}\text { Market } \\
\text { Competitiveness Only }\end{array}$} & Cap. Mkts Comm. & 2 & & & 2 \\
\hline & McKinsey Study & 1 & & & 1 \\
\hline & $\begin{array}{l}\text { Cap. Mkts Comm. \& } \\
\text { McKinsey Study }\end{array}$ & & 1 & & 1 \\
\hline & $\begin{array}{l}\text { Cap. Mkts Comm., } \\
\text { McKinsey Study \& } \\
\text { Chamber Comm'n }\end{array}$ & 2 & & & 2 \\
\hline \multirow{2}{*}{$\begin{array}{l}\text { Market } \\
\text { Competitiveness and } \\
\text { Small-Firm Costs }\end{array}$} & $\begin{array}{l}\text { Cap. Mkts Comm. \& } \\
\text { Chamber Comm'n }\end{array}$ & 1 & & & 1 \\
\hline & No study referenced & 2 & & 1 & 3 \\
\hline \multicolumn{2}{|l|}{ Total } & 8 & 1 & 1 & 10 \\
\hline
\end{tabular}

Appendix Table 2 Notes: The Table summarizes the type of overlap across the SOX critiques and committees tabulated in Tables 2 and 3, which include descriptions of the data, with the additional abbreviation in this table "Cap. Mkts Comm." for "Capital Markets Committee." 
Appendix Table 3: Regional Newspaper and Wire Service Coverage of SOX, 12/1/04-6/10/07

3A: All Regional Newspaper Stories

\begin{tabular}{|c|c|c|c|c|c|}
\hline & 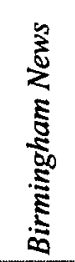 & $\begin{array}{l}0 \\
\vdots \\
0 \\
\vdots \\
\vdots \\
0 \\
0\end{array}$ & 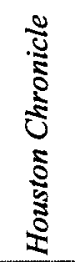 & 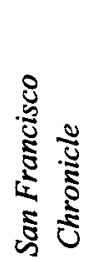 & 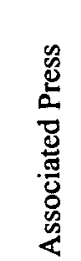 \\
\hline Advisory Committee & 1 & 4 & 3 & 9 & 22 \\
\hline Capital Markets Committee & 0 & 2 & 4 & 1 & 15 \\
\hline Chamber Comm'n & 0 & 0 & 1 & 0 & 8 \\
\hline McKinsey Study & 0 & 1 & 2 & 0 & 4 \\
\hline Market Competitiveness & 3 & 11 & 13 & 12 & 75 \\
\hline Foreign-Market Competitiveness & 3 & 7 & 8 & 5 & 62 \\
\hline Small-Firm Costs & 5 & 8 & 9 & 8 & 31 \\
\hline Advocacy Against Revising Sox & 0 & 3 & 4 & 0 & 4 \\
\hline Total SOX** & 16 & 29 & 51 & 31 & 128 \\
\hline Total Surveyed & 176 & 238 & 352 & 337 & 2177 \\
\hline
\end{tabular}

3B: Regional Newspaper Stories Taken from Wire Services or Other Newspapers

\begin{tabular}{|c|c|c|c|c|}
\hline & 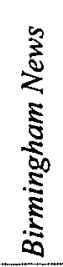 & $\begin{array}{l}0 \\
0 \\
0 \\
5 \\
5 \\
0 \\
0\end{array}$ & 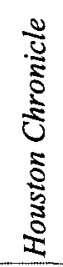 & 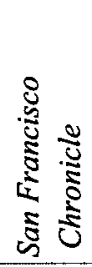 \\
\hline Advisory Committee & 1 & 3 & 1 & 7 \\
\hline Capital Markets Committee & 0 & 1 & 4 & 1 \\
\hline Chamber Comm'n & 0 & 0 & 1 & 0 \\
\hline McKinsey Study & 0 & 1 & 0 & 0 \\
\hline Market competitiveness & 2 & 5 & 6 & 6 \\
\hline Foreign-Market Competitiveness & 2 & 5 & 5 & 4 \\
\hline Small-Firm Costs & 5 & 4 & 6 & 6 \\
\hline Total SOX** & 12 & 12 & 26 & 23 \\
\hline
\end{tabular}


3C: Regional Newspaper Stories Taken from the Associated Press Wire Service

\begin{tabular}{|c|c|c|c|c|}
\hline & 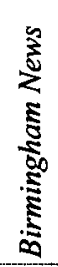 & $\begin{array}{l}0 \\
\delta \\
0 \\
5 \\
5 \\
0\end{array}$ & 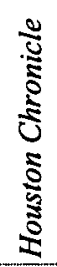 & 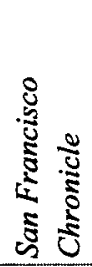 \\
\hline Advisory Committee & 1 & 1 & 1 & 4 \\
\hline Capital Markets Committee & 0 & 1 & 2 & 0 \\
\hline Market Competitiveness & 0 & 2 & 2 & 3 \\
\hline Foreign-Market Competitiveness & 0 & 2 & 2 & 3 \\
\hline Small-Firm Costs & 5 & 2 & 4 & 4 \\
\hline Total SOX** & 8 & 5 & 13 & 10 \\
\hline
\end{tabular}

Appendix Table 3 Notes: Panels B and C of Appendix Table 3 do not include the row "Total Surveyed" because for two papers, the Birmingham and Houston newspapers, every daily edition was read for the entire period to identify the external sourced articles and there is accordingly no total survey count, which is derived from the number of articles identified by the Lexis searches described in the Appendix. The San Francisco Chronicle did not always provide an outsourced article's reporter's affiliation; in all but one such case I was able to identify the reporters' news organization. In a few cases of news briefs, the wire source was not identified (one for Birmingham News and two for Boston Globe). Because the AP wire service reports continuously throughout a day, the search often produced duplicates of the same story as it was updated or rerun over time. The count for AP stories therefore excludes duplicates, which are defined as articles by the same author with the same date or within two days of the first article's publication, that have the same title and content, or different titles but minor differences in content. Articles by reporters associated with Dow Jones or the Wall Street Journal that were identified in the AP search are included in the AP tallies. 
Appendix Table 4: Associated Press and National Newspaper SOX Coverage, $12 / 1 / 2004$ to $6 / 10 / 2007$

\begin{tabular}{|c|c|c|c|c|}
\hline & 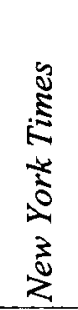 & 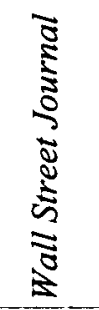 & 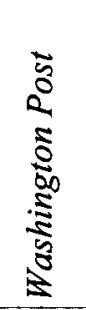 & 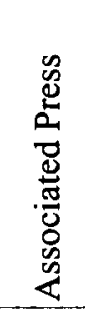 \\
\hline Advisory Committee & 3 & 26 & 12 & 22 \\
\hline Capital Markets Committee & 7 & 11 & 9 & 15 \\
\hline Chamber Comm'n & 2 & 4 & 5 & 8 \\
\hline McKinsey Study & 5 & 7 & 1 & 4 \\
\hline Market Competitiveness & 35 & 84 & 18 & 75 \\
\hline IPO but not Foreign-Market Listing & 2 & 10 & 1 & 8 \\
\hline Going-Private but not Foreign Firm & 3 & 15 & 7 & 5 \\
\hline Foreign-Market Competitiveness & 30 & 59 & 10 & 62 \\
\hline Small-Firm Costs & 6 & 25 & 12 & 31 \\
\hline Advocacy Against Revising SOX & 3 & 0 & 2 & 4 \\
\hline Total SOX & 73 & 166 & 93 & 128 \\
\hline Total Surveyed & 806 & 1344 & 632 & 2177 \\
\hline
\end{tabular}

Appendix Table 4 Notes: Data descriptions are in Table 2 and Appendix Table 3. 
Appendix Table 5: Publication Dates of Regional Newspapers' Associated Press Stories on SOX Critiques and Reports

\begin{tabular}{|c|c|c|c|c|}
\hline $\begin{array}{c}\text { Regional } \\
\text { Newspaper }\end{array}$ & $\begin{array}{l}\text { Regional } \\
\text { Pub. Date }\end{array}$ & $\begin{array}{l}\text { AP Pub. } \\
\text { Date }\end{array}$ & Any National Publication Date & $\begin{array}{c}\text { Different Story Publication } \\
\text { Date }\end{array}$ \\
\hline \multirow{5}{*}{$\begin{array}{l}\text { Birmingham } \\
\text { News }\end{array}$} & $4 / 22 / 2005$ & $4 / 21 / 2005$ & & \\
\hline & $5 / 17 / 2005$ & $5 / 16 / 2005$ & & \\
\hline & $5 / 9 / 2006^{*}$ & $5 / 8 / 2006$ & $5 / 8 / 2006 \quad \& 5 / 9 / 2006$ & \\
\hline & $12 / 12 / 2006^{*}$ & $12 / 11 / 2006$ & $12 / 11 / 2006 \quad \& \quad 12 / 12 / 2006$ & \\
\hline & $12 / 14 / 2006^{*}$ & $12 / 13 / 2006$ & $12 / 13 / 2006$ & \\
\hline \multirow{4}{*}{ Boston Globe } & $11 / 17 / 2006$ & $11 / 16 / 2006$ & & \\
\hline & $11 / 21 / 2006^{*}$ & $11 / 20 / 2006$ & $11 / 20 / 2006 \& 1 / 21 / 2006$ & \\
\hline & $12 / 12 / 2006^{*}$ & $12 / 11 / 2006$ & $12 / 11 / 2006 \& 2 / 12 / 2006$ & \\
\hline & $12 / 25 / 2006^{*}$ & $12 / 24 / 2006$ & & $12 / 22 / 2006$ \\
\hline \multirow{5}{*}{$\begin{array}{l}\text { Houston } \\
\text { Chronicle }\end{array}$} & $5 / 9 / 2006^{*}$ & $5 / 8 / 2006$ & $5 / 8 / 2006 \quad \& 5 / 9 / 2006$ & \\
\hline & $11 / 21 / 2006^{*}$ & $11 / 20 / 2006$ & $11 / 20 / 2006 \& 11 / 21 / 2006$ & \\
\hline & $12 / 3 / 2006$ & $11 / 30 / 2006$ & & $11 / 30 / 2006 \quad \& \quad 12 / 1 / 2006$ \\
\hline & $12 / 12 / 2006^{*}$ & $12 / 11 / 2006$ & $12 / 11 / 2006 \& 12 / 12 / 2006$ & \\
\hline & $12 / 16 / 2006$ & $12 / 13 / 2006$ & $12 / 13 / 2006$ & \\
\hline \multirow{8}{*}{$\begin{array}{l}\text { San } \\
\text { Francisco } \\
\text { Chronicle }\end{array}$} & $3 / 4 / 2005$ & $3 / 3 / 2005$ & $3 / 3 / 2005$ & \\
\hline & $9 / 22 / 2005$ & $9 / 21 / 2005$ & $9 / 19 / 2005 \quad \& \quad 9 / 22 / 2005$ & $9 / 15 / 2005$ \\
\hline & $4 / 21 / 2006$ & $4 / 20 / 2006$ & $4 / 19 / 2006 \quad \& \quad 4 / 21 / 2006$ & \\
\hline & $5 / 18 / 2006$ & $5 / 17 / 2006$ & $5 / 18 / 2006$ & \\
\hline & $11 / 10 / 2006$ & $11 / 9 / 2006$ & & $11 / 10 / 2006$ \\
\hline & $11 / 26 / 2006$ & $11 / 24 / 2006$ & & $11 / 22 / 2006 \& 11 / 25 / 2006$ \\
\hline & $12 / 14 / 2006^{*}$ & $12 / 13 / 2006$ & $12 / 12 / 2006 \& 12 / 13 / 2006$ & \\
\hline & $12 / 26 / 2006^{*}$ & $12 / 24 / 2006$ & & $12 / 22 / 2006$ \\
\hline
\end{tabular}

Appendix Table 5 Notes: The table indicates publication dates of Associated Press articles referencing either SOX critiques or reports tracked in Table 2, and published in regional newspapers, relative to the date the article appeared on the wire and articles on the same topic appeared in any of the national newspapers tracked in that table. "AP" indicates Associated Press; "Pub" indicates publication; * indicates same AP article reprinted in more than one regional newspaper; "Different Story" indicates the national newspaper story was on the same topic as the AP story but was completely different in content. 
Appendix Table 6: Regional Newspaper Reporting Day in Relation to National Newspaper Reporting Day

6A: Regional Newspaper Reporting Day in Relation to National Newspaper Reporting Day: All Sequential Stories.

\begin{tabular}{|l|c|c|c|c|c|c|}
\hline & \multicolumn{2}{|c|}{ Regional: } & \multicolumn{2}{|c|}{ Staff Story } & \multicolumn{2}{c|}{ Regional: } \\
\cline { 2 - 7 } & Mkt Comp & Small & Report & Mkt Comp & Small & Report \\
\hline Same Day & 2 & 0 & 4 & 6 & 10 & 15 \\
\hline 1 Day After & 1 & 0 & 0 & 1 & 2 & 1 \\
\hline 2 Days After & 5 & 0 & 0 & 0 & 1 & 0 \\
\hline 3 Days After & 1 & 0 & 0 & 1 & 1 & 1 \\
\hline 4 Days After & 1 & 0 & 0 & 1 & 0 & 0 \\
\hline $\begin{array}{l}\text { No Relation in } \\
\text { Time }\end{array}$ & 13 & 9 & 4 & 7 & 7 & 3 \\
\hline
\end{tabular}

6B: Regional Newspaper Reporting Day in Relation to National Newspaper Reporting Day: Misclassified Sequential Stories Excluded

\begin{tabular}{|c|c|c|c|c|c|c|}
\hline & \multirow{2}{*}{$\frac{\text { Regional: }}{\text { Mkt Comp }}$} & \multicolumn{2}{|c|}{ Staff Story } & \multicolumn{3}{|c|}{ Regional: Wire Story } \\
\hline & & Small & Report & Mkt Comp & Small & Report \\
\hline Same Day & 2 & 0 & 4 & 6 & 10 & 15 \\
\hline 1 Day After & 0 & 0 & 0 & 0 & 2 & 1 \\
\hline 2 Days After & 2 & 0 & 0 & 0 & 0 & 0 \\
\hline 3 Days After & 0 & 0 & 0 & 1 & 1 & 1 \\
\hline 4 Days After & 0 & 0 & 0 & 1 & 0 & 0 \\
\hline $\begin{array}{l}\text { No Relation in } \\
\text { Time }\end{array}$ & 13 & 9 & 4 & 7 & 7 & 3 \\
\hline
\end{tabular}

Appendix Table 6 Notes: The table breaks down regional coverage by SOX critique type, where "Mkt Comp" stands for market competitiveness critiques, "Small" for small-firm cost critiques, and "Report" for an article referencing one of the commissioned reports, and by whether the story was written by the newspaper's internal staff ("Staff") or was taken from a wire service or other newspaper ("Wire Story"), and then tallies those articles by the date on which they were published in a regional newspaper in relation to the date a story of the same critique type was published in a national newspaper. "No Relation in Time" indicates a story in a regional newspaper published more than five days after any story on a similar critique type was published in a national newspaper; "Same Day" indicates that both a regional and national newspaper published a story on the same SOX critique type on the same day; and "1 Day After" indicates a regional newspaper article was published one day after an article of the same critique type was published in a national newspaper, and so forth. To provide a conservative estimate of the independence of the regional newspapers' reporting, when there was any possibility that their coverage followed a national newspaper, it was so classified in 
Panel A of the Table. Panel B of the Table excludes from the tally both regional stories counted as " 1 Day After" in Panel A which were in fact published both on the same day and one day after a story of the same critique type was published in a national newspaper; and regional stories of the same critique type published after a national story that are very different in content from that of the national story and that are counted in Panel A as published a number of days after the national story rather than as no relation in time. On a few occasions an article in a regional newspaper is not identified as coming from a wire service but the reporter in the byline is affiliated with a wire service and had published the same or similar story on the wire previously; such articles are counted as "Wire," and not "Staff," stories. 
HeinOnline -- 26 Yale J. on Reg. 3422009 